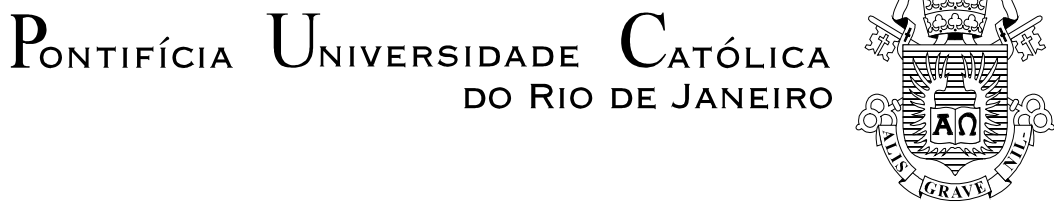

Bruno Eduardo Marques Mendes

O Papel da Comunicação no Gerenciamento de Projetos

Dissertação de Mestrado

Dissertação apresentada ao Programa de Pós-graduação em Administração de Empresas da PUC-Rio como requisito parcial para obtenção do grau de Mestre em Administração de Empresas.

Orientadora: Profa. Andréa Cherman

Rio de Janeiro

Abril de 2017 


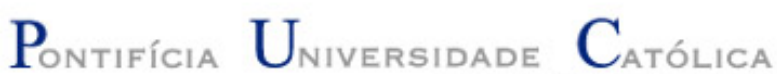

Bruno Eduardo Marques Mendes

\section{O Papel da Comunicação no Gerenciamento de Projetos}

Dissertação apresentada como requisito parcial para obtenção do grau de Mestre pelo Programa de PósGraduação em Administração de Empresas do Departamento de Administração da PUC-Rio. Aprovada pela Comissão Examinadora abaixo assinada.

Profa. Andrea Cherman

Orientadora

Departamento de Administração - PUC-Rio

Profa. Alessandra de Sá Mello da Costa

Departamento de Administração - PUC-Rio

Prof. Marcos Lopez Rego

PUC-Rio

Prof. Mario Couto Soares Pinto

Instituto Brasileiro de Mercado de Capitais

Profa. Mônica Herz

Vice-Decana de Pós-Graduação do CCS - PUC-Rio

Rio de Janeiro, 10 de abril de 2017 
Todos os direitos reservados. É proibida a reprodução total ou parcial do trabalho sem autorização da universidade, do autor e da orientadora.

\section{Bruno Eduardo Marques Mendes}

Graduou-se em Informática no Centro Universitário da Cidade. Possui MBA em Gerenciamento de Projetos pela Universidade Gama Filho. Atua como Analista de Sistemas SAP, na área de Tecnologia da Informação, em uma empresa de grande porte que atua nas áreas de operações portuárias, marítimas e logística.

Ficha catalográfica

Mendes, Bruno Eduardo Marques

O Papel da Comunicação no Gerenciamento de Projetos/ Bruno Eduardo Marques Mendes; orientadora: Andréa Cherman. - 2017.

$102 \mathrm{f.;} ; 30 \mathrm{~cm}$

Dissertação (mestrado) - Pontifícia Universidade Católica do Rio de Janeiro, Departamento de Administração, 2017.

Inclui bibliografia

1. Administração - Teses. 2. Projeto. 3. Gerenciamento de Projetos. 4. Comunicação. 5. Mudanças. I. Cherman, Andréa. II. Pontifícia Universidade Católica do Rio de Janeiro. Departamento de Administração. III. Título.

CDD: 658 
Este trabalho é dedicado a Deus, que em sua infinita graça, me abençoou com esta oportunidade.

Dedico-o também à minha esposa Adriana e aos meus pais José (in memoriam) e Maria, por toda dedicação e amor. 


\section{Agradecimentos}

À minha orientadora, Andréa Cherman, pela sua paciência, compreensão e encorajamento, nesta inesquecível jornada. Por ter acreditado em mim. Pelas palavras amigas e também pelas firmes nos momentos certos.

Ao professor José Roberto Gomes da Silva (in memoriam). Por seu legado. Em seus empolgantes trabalhos em comunicação organizacional encontrei a inspiração que me conduziu à esta pesquisa.

À professora Alessandra de Sá Mello da Costa, por sua valiosa contribuição para este trabalho e por sua participação na banca.

Aos professores também membros da banca, Marcos Lopez Rego e Mario Couto Soares Pinto, por me privilegiarem com sua participação.

À minha família, aos meus pastores, aos meus amigos e aos membros da minha igreja, por sua por sua paciência e compreensão. Pelos incentivos e pelas orações.

Aos entrevistados que muito generosamente se disponibilizaram em um período tão difícil para participarem deste trabalho de pesquisa. 


\section{Resumo}

Mendes, Bruno Eduardo Marques; Cherman, Andréa (Orientadora). O papel da comunicação no gerenciamento de projetos. Rio de Janeiro, 2017. 102p. Dissertação de Mestrado - Departamento de Administração, Pontifícia Universidade Católica do Rio de Janeiro.

Diante do atual cenário de constantes mudanças organizacionais, muitos autores têm se dedicado ao estudo e pesquisa em gerenciamento de projetos, objetivando contribuir para o processo de mudanças implementadas por meio de projetos. Partindo do pressuposto de que a comunicação é a arena na qual as pessoas e a própria organização podem criar sentido (WEICK, 1995), essa dissertação propôs-se a compreender como a comunicação é percebida pelos indivíduos e como esta afeta os processos de criação de sentido quando estes indivíduos participam de um processo de mudança organizacional provocado por um projeto de implementação de um ERP - Enterprise Resource Planning. Foi realizada uma pesquisa de campo tomando-se um projeto de implementação de ERP como estudo de caso. A comunicação do projeto foi analisada primeiramente sob uma perspectiva positivista, e posteriormente realizou-se um contraponto, no qual o presente trabalho se aprofundou, com uma perspectiva interpretativista, utilizando o modelo teórico proposto pela "Escola de Montreal”. Os resultados da pesquisa evidenciaram a importância do papel da comunicação como constitutiva do projeto e da própria organização (TAYLOR e CASALI, 2010).

\section{Palavras-chave}

Projeto; Gerenciamento de Projetos; Comunicação; Mudanças. 


\section{Abstract}

Mendes, Bruno Eduardo Marques; Cherman, Andréa (Advisor). The Role of Communication in Project Management. Rio de Janeiro, 2017. 102p. Dissertação de Mestrado - Departamento de Administração, Pontifícia Universidade Católica do Rio de Janeiro.

Given the current scenario of constant organizational changes, many authors have been dedicated to study and research in project management, aiming to contribute to the process of changes implemented through projects. Based on the assumption that communication is the arena in which people and the organization itself can create meaning (WEICK, 1995), this dissertation aims to understand how communication is perceived by individuals and how it affects the processes of creation of sense when these individuals participate in a process of organizational change brought about by an implementation project of an ERP Enterprise Resource Planning. A field survey was carried out by taking an ERP implementation project as a case study. The communication of the project was analyzed first from a positivist perspective, and later a counterpoint was made, in which the present work has deepened, with an interpretative perspective, using the theoretical model proposed by the "Montreal School". The results of the research evidenced the importance of the role of communication as constitutive of the project and of the organization itself (TAYLOR and CASALI, 2010).

\section{Keywords}

Project; Project management; Communication; Changes. 


\section{Sumário}

1. O problema 14

1.1. Introdução 14

1.2. Objetivo final 17

1.3. Objetivos intermediários 17

1.4. Delimitação do estudo 18

1.5. Relevância do estudo 19

2. Referencial teórico 21

2.1. Gerenciamento de projetos $\quad 21$

2.1.1. Introdução 21

2.1.2. Evolução do gerenciamento de projetos 21

2.1.3. O que é um projeto? $\quad 24$

2.1.4. O que é gerenciamento de projetos? 25

2.1.5. Processos de gerenciamento de projetos $\quad 29$

2.1.6. Áreas de conhecimento em gerenciamento de projetos 30

2.2. Comunicaçao organizacional $\quad 40$

2.2.1. História e desenvolvimento da comunicação organizacional 41

2.2.2. Visões paradigmáticas da comunicação organizacional 42

2.2.3. Comunicação nas organizações $\quad 45$

2.2.4. Comunicação como organização 47

2.2.5. Organização como comunicação 49

3. Metodologia $\quad 55$

3.1. Seleção dos sujeitos

3.2. Procedimentos e Instrumentos de Coleta de Dados 60

3.3. Tratamento dos dados 61

3.4. Limitações do método 62

4. Caso 63

4.1. O Grupo ABC 63

4.2. A área de Desenvolvimento Organizacional 65

4.3. Projeto Novos Horizontes 67

5. Análise e interpretação dos resultados da pesquisa 71

5.1. Análise do conteúdo das entrevistas $\quad 71$

5.1.1. Gerenciamento de projetos $\quad 71$

5.1.2. Comunicação organizacional $\quad 78$

5.1.3. Categorização da Comunicação em Projetos 86

5.2. Comunicação Instrumental do Projeto 87

5.3. Comunicação Constitutiva do Projeto 89

6. Conclusão 91

$\begin{array}{lr}\text { 7. Referências bibliográficas } & 97\end{array}$

$\begin{array}{ll}\text { 8. Anexo I } & 101\end{array}$ 


\section{Lista de figuras}

Figura 1: Grupos de processos de gerenciamento de projetos. 27

Figura 2: Metodologia ASAP SAP. $\quad 29$

Figura 3: Visão geral do gerenciamento das comunicações do projeto. 35

Figura 4: Modelo Básico de Comunicação. 37

Figura 5: Os quatro paradigmas das ciências sociais. 43

Figura 6: A Dinâmica Texto-Conversação.

Figura 7: Coorientação através da Conversação como a Unidade Relacional Essencial de Organização.

Figura 8: Áreas representativas do projeto. 58

Figura 9: Frentes de atuação da área de DHO na empresa ABC. 66

Figura 10: Visão macro do Cronograma do Projeto Novos Horizontes

- Fase I. $\quad 69$

Figura 11: Organograma do Projeto. 69

$\begin{array}{ll}\text { Figura 12: Governança do Projeto. } & 71\end{array}$ 


\section{Lista de tabelas}

Tabela 1: Dados demográficos pessoais. 58

Tabela 2: Dados demográficos organizacionais. $\quad 59$

Tabela 3: Cargo versus função no Projeto. 59

\section{Lista de quadros}

Quadro 1: Principais associações de gerenciamento de projetos.

Quadro 2: Grupo de processos de gerenciamento de projetos e mapeamento das áreas de conhecimento. 


\section{O OPERÁRIO EM CONSTRUÇÃO}

\section{Vinícius de Moraes}

E o Diabo, levando-o a um alto monte, mostrou-lhe num momento de tempo todos os reinos do mundo. E disse-lhe o Diabo:

- Dar-te-ei todo este poder e a sua glória, porque a mim me foi entregue e dou-o a quem quero; portanto, se tu me adorares, tudo será teu.

E Jesus, respondendo, disse-lhe:

- Vai-te, Satanás; porque está escrito: adorarás o Senhor teu Deus e só a Ele servirás.

Lucas, cap. 5, vs. 5-8.

Era ele que erguia casas

Onde antes só havia chão.

Como um pássaro sem asas

Ele subia com as casas

Que lhe brotavam da mão.

Mas tudo desconhecia

De sua grande missão:

Não sabia, por exemplo

Que a casa de um homem é um

templo

Um templo sem religião

Como tampouco sabia

Que a casa que ele fazia

Sendo a sua liberdade

Era a sua escravidão.

De fato, como podia

Um operário em construção

Compreender por que um tijolo

Valia mais do que um pão?

Tijolos ele empilhava

Com pá, cimento e esquadria

Quanto ao pão, ele o comia...

Mas fosse comer tijolo!

E assim o operário ia

Com suor e com cimento

Erguendo uma casa aqui

Adiante um apartamento

Além uma igreja, à frente

Um quartel e uma prisão:

Prisão de que sofreria

Não fosse, eventualmente

Um operário em construção.

Mas ele desconhecia

Esse fato extraordinário:
Que o operário faz a coisa

E a coisa faz o operário.

De forma que, certo dia

À mesa, ao cortar o pão

O operário foi tomado

De uma súbita emoção

Ao constatar assombrado

Que tudo naquela mesa

- Garrafa, prato, facão -

Era ele quem os fazia

Ele, um humilde operário,

Um operário em construção.

Olhou em torno: gamela

Banco, enxerga, caldeirão

Vidro, parede, janela

Casa, cidade, nação!

Tudo, tudo o que existia

Era ele quem o fazia

Ele, um humilde operário

Um operário que sabia

Exercer a profissão.

Ah, homens de pensamento

Não sabereis nunca o quanto

Aquele humilde operário

Soube naquele momento!

Naquela casa vazia

Que ele mesmo levantara

Um mundo novo nascia

De que sequer suspeitava.

O operário emocionado

Olhou sua própria mão

Sua rude mão de operário

De operário em construção

E olhando bem para ela

Teve um segundo a impressão 
De que não havia no mundo Coisa que fosse mais bela.

Foi dentro da compreensão

Desse instante solitário

Que, tal sua construção

Cresceu também o operário.

Cresceu em alto e profundo

Em largo e no coração

E como tudo que cresce

Ele não cresceu em vão

Pois além do que sabia

- Exercer a profissão -

O operário adquiriu

Uma nova dimensão:

A dimensão da poesia.

E um fato novo se viu

Que a todos admirava:

O que o operário dizia

Outro operário escutava.

E foi assim que o operário

Do edifício em construção

Que sempre dizia sim

Começou a dizer não.

E aprendeu a notar coisas

A que não dava atenção:

Notou que sua marmita

Era o prato do patrão

Que sua cerveja preta

Era o uísque do patrão

Que seu macacão de zuarte

Era o terno do patrão

Que o casebre onde morava

Era a mansão do patrão

Que seus dois pés andarilhos

Eram as rodas do patrão

Que a dureza do seu dia

Era a noite do patrão

Que sua imensa fadiga

Era amiga do patrão.

E o operário disse: Não!

E o operário fez-se forte

Na sua resolução.

Como era de se esperar

As bocas da delação

Começaram a dizer coisas
Aos ouvidos do patrão.

Mas o patrão não queria

Nenhuma preocupação

- "Convençam-no" do contrário -

Disse ele sobre o operário

$\mathrm{E}$ ao dizer isso sorria.

Dia seguinte, o operário

Ao sair da construção

Viu-se súbito cercado

Dos homens da delação

E sofreu, por destinado

Sua primeira agressão.

Teve seu rosto cuspido

Teve seu braço quebrado

Mas quando foi perguntado

O operário disse: Não!

Em vão sofrera o operário

Sua primeira agressão

Muitas outras se seguiram

Muitas outras seguirão.

Porém, por imprescindível

Ao edifício em construção

Seu trabalho prosseguia

E todo o seu sofrimento

Misturava-se ao cimento

Da construção que crescia.

Sentindo que a violência

Não dobraria o operário

Um dia tentou o patrão

Dobrá-lo de modo vário.

De sorte que o foi levando

Ao alto da construção

E num momento de tempo

Mostrou-lhe toda a região

E apontando-a ao operário

Fez-lhe esta declaração:

- Dar-te-ei todo esse poder

E a sua satisfação

Porque a mim me foi entregue

E dou-o a quem bem quiser.

Dou-te tempo de lazer

Dou-te tempo de mulher.

Portanto, tudo o que vês

Será teu se me adorares

$E$, ainda mais, se abandonares

$\mathrm{O}$ que te faz dizer não.

Disse, e fitou o operário 
Que olhava e que refletia

Mas o que via o operário

O patrão nunca veria.

O operário via as casas

E dentro das estruturas

Via coisas, objetos

Produtos, manufaturas.

Via tudo o que fazia

O lucro do seu patrão

E em cada coisa que via

Misteriosamente havia

A marca de sua mão.

E o operário disse: Não!

- Loucura! - gritou o patrão

Não vês o que te dou eu?

- Mentira! - disse o operário

Não podes dar-me o que é meu.

E um grande silêncio fez-se

Dentro do seu coração

Um silêncio de martírios

Um silêncio de prisão.
Um silêncio povoado

De pedidos de perdão

Um silêncio apavorado

Com o medo em solidão.

Um silêncio de torturas

E gritos de maldição

Um silêncio de fraturas

A se arrastarem no chão.

E o operário ouviu a voz

De todos os seus irmãos

Os seus irmãos que morreram

Por outros que viverão.

Uma esperança sincera

Cresceu no seu coração

E dentro da tarde mansa

Agigantou-se a razão

De um homem pobre e esquecido

Razão porém que fizera

Em operário construído

O operário em construção. 


\section{O problema}

\section{1}

\section{Introdução}

Já em meados do século VI a.C., encontramos manifestações da inquietação humana em relação à questão da mudança. Neste período présocrático, o filósofo grego Heráclito desenvolveu o pensamento filosófico de que nada é permanente, exceto a mudança. Tudo flui, nada permanece, a mudança das coisas é constante e eterna - esta é a tese que tornou o filósofo conhecido até os dias atuais (MARTINS, 2007).

Como observado por Heráclito, o mundo sempre esteve em um processo de constantes mudanças. O que observamos em nossa era contemporânea, no entanto, é que não somente a mudança ainda permanece, mas uma das principais mudanças do mundo atual reside na velocidade em que as mudanças ocorrem.

Se para efeitos comparativos, observarmos a evolução na linha do tempo de algumas invenções dos dois últimos séculos, verificaremos, por exemplo, que o tempo de difusão da Internet é incomparavelmente menor que os demais. A eletricidade, inventada em 1873, atingiu 50 milhões de usuários depois de 46 anos de existência; o telefone (1876), demorou 35 anos para atingir esta mesma marca; o automóvel (1886), 55 anos; o rádio (1906), 22 anos; a televisão (1926), 26 anos e o microcomputador (1975), 16 anos (BALDESSAR, 2005). A Internet, por sua vez, criada na década de 90, tem atualmente mais de 3 bilhões de usuários, segundo dados do relatório anual divulgado pela ITU, International Telecommunication Union (ITU, 2015).

Neste contexto, nos confrontamos com um mundo em um ritmo de transformações cada vez mais acelerado, com relevante influência de revoluções tecnológicas provenientes da tecnologia da informação, as quais ocupam um lugar destacado no cotidiano tanto dos indivíduos, quanto das organizações, gerando mudanças profundas nas realidades de ambos. 
Diante de um mundo em constante mudança e repleto de incertezas, indivíduos e organizações na sociedade atual têm sido confrontados com grandes desafios (KUNSCH, 2008).

No ambiente organizacional, doravante, a mudança não pode ser compreendida somente pelo prisma de mudanças tecnológicas, estratégicas, ou de processos. A mudança organizacional reflete também alterações na interação entre o indivíduo e a organização, entre o indivíduo e as demais pessoas da organização, da organização com o ambiente no qual ela está inserida, do indivíduo consigo mesmo. A mudança se constitui, antes de qualquer coisa, num processo que se concretiza socialmente nas interações cotidianas, o qual para ser compreendido em sua plenitude, tem que levar em consideração o contexto no qual se desenvolve, além de outras importantes dimensões, relativas à ação social na organização e às pessoas que dela participam (SILVA, 2001 p. 24).

Diante desse complexo cenário de constantes mudanças organizacionais, muitos autores têm se dedicado ao estudo e pesquisa em gerenciamento de projetos, buscando contribuir com as organizações no alcance de melhores resultados. Deste modo, o conhecimento oriundo do campo de gerenciamento de projetos tem se difundido largamente nas práticas das organizações contemporâneas, propondo-se auxiliá-las no gerenciamento de mudanças.

O conceito formal de gerenciamento de projetos surgiu discretamente na literatura no final da década de 50, inicialmente relacionado com projetos militares e de construção civil. Provavelmente, a primeira publicação que descreveu o gerenciamento de projeto surgiu em 1697, escrita por Daniel Defoe, sob o título Um Ensaio sobre Projetos (CLELAND, 2004).

A $8^{a}$ pesquisa anual de gerenciamento de projetos globais realizada pelo PMI concluiu que continua sendo entendimento comum entre as organizações que incorporam o conhecimento de gerenciamento de projetos em suas práticas que, quando se implementa práticas comprovadas de gerenciamento de projetos, os projetos organizacionais cumprem seus objetivos e a intenção originais do negócio com muito mais frequência (PMI, 2016).

Considerando-se que há uma percepção comum de que existem benefícios comprovados, tangíveis e intangíveis, na aplicação de um corpo de conhecimentos em gerenciamento de projetos nas organizações, boa parte dos esforços empreendidos na área de gerenciamento de projetos tem primado pela 
identificação de práticas que contribuam para o sucesso dos projetos. E entre estas práticas, a comunicação é apontada como a área de conhecimento que mais pode afetar o engajamento das pessoas e a redução de suas resistências.

O guia internacional de melhores práticas em gerenciamento de projetos, intitulado Guia PMBOK (PMI, 2013), sigla para Project Management Body of Knowledge, publicado pelo PMI, sigla para Project Management Institute, menciona que o sucesso do gerenciamento de projetos em uma organização é altamente dependente de um estilo de comunicação organizacional eficaz (PMI, 2013, p. 21).

Dada a diversidade de possibilidades da aplicação de um corpo de conhecimento em gerenciamento de projetos, o presente trabalho se propõe a pesquisar um tipo específico de projeto - a implementação de sistemas do tipo $E R P$, sigla em inglês para Enterprise Resource Planning. Em português este tipo de sistema também é comumente conhecido como SIG, sigla para Sistemas Integrados de Gestão. Toda implementação de um sistema ERP é realizada no formato de projeto, utilizando-se as práticas de gerenciamento de projetos, incluindo o gerenciamento das comunicações. No entanto, a abordagem usual normalmente visualiza a comunicação numa perspectiva de contenção, a qual considera a comunicação como algo localizado dentro de uma estrutura organizacional material, concretizada, reificada, sem levar em consideração a criação de sentido estabelecida pelo processo comunicacional.

O processo de mudança provocado por uma implantação de ERP é na maior parte das vezes conduzido com vistas a se atingir aumento de performance, redução de custos, ou outros benefícios que representem uma contrapartida que justifique o investimento realizado pela organização. Estes benefícios representam variáveis importantes a serem consideradas para o crescimento e sobrevivência das organizações. No entanto, o primor exclusivo pelo destaque de benefícios objetivos, tem preterido o reflexo subjetivo sobre os indivíduos impactados pelo processo de mudança, de tal modo que tanto os benefícios, quanto os problemas resultantes deste reflexo sejam desapercebidos, ou até mesmo ignorados, em muitos projetos organizacionais.

Diante desta perspectiva, o presente trabalho busca abordar a problemática envolvida no processo de mudança adotando um enfoque interpretativo para a análise da comunicação aplicada ao Gerenciamento de 
Projetos, com foco específico em projetos de implementação de sistema $E R P$, Enterprise Resource Planning. O pressuposto básico é o de que a comunicação organizacional é o meio pelo qual os indivíduos criam sentido (WEICK, 1995), assim como a comunicação organizacional é constitutiva da própria organização (TAYLOR et al. 2004). Essa reflexão remete essa pesquisa à seguinte questão:

Como a comunicação é percebida pelos indivíduos e como esta afeta os processos de criação de sentido quando estes indivíduos participam de um processo de mudança organizacional provocado por um projeto de implementação de um ERP?

\section{2}

\section{Objetivo final}

Considerando a comunicação organizacional como constitutiva das organizações e como um processo de significação das mudanças na perspectiva dos indivíduos, o objetivo principal do presente estudo, conforme sugerido pela questão de pesquisa, consiste em analisar como a comunicação organizacional é percebida pelos indivíduos e como esta influencia os processos de criação de sentido quando estes indivíduos participam de um processo de mudança organizacional provocado por um projeto de implementação de um ERP.

\section{3}

\section{Objetivos intermediários}

Como parte fundamental para o alcance do objetivo acima proposto, a pesquisa possui alguns objetivos intermediários e secundários:

- Compreender como os indivíduos percebem a comunicação organizacional, analisando-se suas percepções sob a luz das perspectivas da comunicação como contidas nas organizações, como fenômeno equivalente à própria organização, e como constitutiva da própria organização;

- Identificar como os indivíduos percebem a relevância do conhecimento formal em gerenciamento de projetos e do papel da comunicação na realização de um projeto organizacional; 
- Identificar oportunidades de contribuição de diferentes perspectivas em comunicação organizacional para o gerenciamento de projetos.

\section{4}

\section{Delimitação do estudo}

A primeira delimitação de estudo se refere ao fato de que as percepções dos indivíduos são analisadas dentro do contexto organizacional. Aspectos relacionados à vida social dos indivíduos, como um fenômeno social amplo, não são especificamente tratados nesta pesquisa. É notório, porém, que os contextos (externo ou interno à empresa) se influenciam mutuamente e que vários aspectos ligados à vida social do indivíduo fora da organização podem ser úteis no entendimento de como os indivíduos interpretam a realidade. Cabe destacar, no entanto, que a análise detalhada destes fenômenos está fora do escopo de estudo da presente pesquisa, dado o foco deste trabalho se propor a compreender como a comunicação influencia a construção de sentido dos indivíduos quando participam de projetos organizacionais.

A segunda delimitação de estudo deste trabalho está no tipo de projeto analisado. O escopo de estudo restringiu-se a projetos de implementação de sistemas do tipo ERP, Enterprise Resource Planning, em português SIG, Sistemas Integrados de Gestão.

Quanto à mudança, de acordo com o tipo de classificação utilizada por Silva (2001), trata-se daquela que surge de uma decisão (consciente) interna ou externa da organização (mudança intencional); que é controlada pela cúpula organizacional (mudança dirigida); que envolve uma grande gama de dimensões (mudança macro); que promove grandes alterações no conjunto de dimensões afetadas (mudança radical); que tende a afetar o comportamento humano na organização, mais especificamente, aquela que busca, mesmo que indiretamente, a alteração do perfil dos membros organizacionais (mudança humana/social).

A natureza do conceito de mudança apresentado determinou a escolha de um estudo de caso: A implementação do ERP SAP na área de recursos humanos da empresa $\mathrm{ABC}$. De acordo com o referencial teórico utilizado nessa pesquisa foi necessário, no entanto, trabalhar fundamentalmente com o conceito de mudança percebida (presente nas narrativas dos participantes do projeto). 


\section{5}

\section{Relevância do estudo}

O presente estudo justifica-se a partir das seguintes constatações:

Organizações em todo o mundo reservam uma parcela considerável de seus orçamentos de TI para a implementação e manutenção de um sistema ERP. E mesmo que majoritariamente as organizações compreendam ser assertivas em suas decisões de investir em ERP, há artigos publicados indicando que a implementação bem-sucedida de um ERP continua sendo uma experiência desafiadora e muitas vezes frustrante. Muitas organizações que comprometeram recursos organizacionais e financeiros significativos para suas implementações de ERP encontraram desafios inesperados na implementação do projeto (BEATTY e WILLIAMS, 2006).

Deste modo, pode-se dizer que ainda há muitas oportunidades de investigações que contribuam para o sucesso de projetos organizacionais desta magnitude. Quanto ao conceito de sucesso de um projeto organizacional, se recorrermos ao Guia PMBOK (PMI, 2013), este nos apresenta a definição de que o sucesso de um projeto organizacional é determinado em função de metas préestabelecidas como o escopo, tempo, custo, qualidade, recursos e risco (PMI, 2013, p. 35).

Neves et al. (2016), em contrapartida, argumentam que embora as organizações recursivamente adotem critérios tradicionais de avaliação de desempenho dos projetos tal como o definido pelo Guia PMBOK (PMI, 2013), o sucesso do projeto fortemente está na percepção das partes interessadas do projeto e que, portanto, gerir as expectativas e ter uma forte sensibilidade para percepções dos stakeholders são fatores fundamentais para o sucesso no gerenciamento de projetos.

Não que os critérios objetivos de avaliação de sucesso do projeto não sejam importantes, ao contrário, eles são fundamentais. Contudo, fatores subjetivos relacionados com as expectativas das partes interessadas devem ser compreendidos como igualmente relevantes.

É neste ponto que a comunicação revela a importância de seu papel. Conforme preconizado pelo Guia PMBOK (PMI, 2013, p. 287), a comunicação cria uma ponte entre as diversas partes interessadas do projeto, as quais podem ter 
diferenças culturais e organizacionais, diferentes níveis de conhecimento, e diversas perspectivas e interesses que podem impactar o resultado do projeto. Não por um acaso, portanto, os gerentes de projeto dedicam a maior parte do seu tempo no projeto se comunicando, tanto com os membros da equipe do projeto, quanto com as demais partes interessadas do projeto.

Pode-se dizer, portanto, que a relevância deste estudo consiste:

- Na identificação de formas de gestão da comunicação, dentro do escopo de gerenciamento de projetos em implementações de um $E R P$, que contribuam para a melhoria do processo de mudanças;

- Na identificação de práticas em projetos que tratem a comunicação como uma arena de construção de significados, como processo de constituição social da ação da mudança, como fenômeno constitutivo da própria organização, e não somente como uma ferramenta de transmissão eficaz da informação e;

- Na busca de uma melhor compreensão da dinâmica da comunicação desencadeada por um projeto de implementação de um ERP. 


\section{Referencial teórico}

\section{1}

\section{Gerenciamento de projetos}

\subsection{1}

Introdução

Esta seção tem por objetivo discorrer sobre o que é gerenciamento de projetos, fornecendo conceitos e definições que visam estruturar um modelo mental que possibilite compreender como o corpo de conhecimentos em gerenciamento de projetos é normalmente estruturado na contemporaneidade.

É apresentada uma breve evolução histórica do gerenciamento de projetos, seguido do atual modelo de gerenciamento de projetos proposto pelo PMI, constituído de 11 áreas de conhecimentos e 5 grupos de processos.

\subsection{2}

\section{Evolução do gerenciamento de projetos}

Desde a antiguidade os projetos desempenham um papel fundamental no processo de mudança das sociedades. Segundo Defoe (1887[1697]) a prática de projetos remonta tempos tão antigos quanto a era de Adão, cujo filho mais velho, Caim, se empenhou em projetos de construção de instrumentos artesanais para seu trabalho como lavrador. O autor cita ainda outros exemplos da narrativa bíblica, tais como a construção da arca de Noé e a construção da torre de Babel, como forma de ilustrar o quanto os projetos estão presentes como prática na história da humanidade desde os tempos mais antigos.

Com efeito, o gerenciamento de projetos pode ser encontrado em diferentes construções de diversos artefatos históricos e benfeitorias culturais, ao longo da história da humanidade. Por exemplo, o Grande Canal da China, o mais longo e antigo canal do mundo, com 1794 quilômetros de comprimento, 24 eclusas e cerca de 60 pontes, foi construído no ano 486 a.C. e foi incluído na lista 
de patrimônio mundial da UNESCO por ser uma construção gigantesca, criando o maior e mais extenso projeto de engenharia antes da Revolução Industrial (UNESCO).

Em períodos mais modernos, outros projetos têm desempenhado um papel chave na mudança da sociedade, tal como a construção do Canal do Panamá, inaugurado em 1914, considerado uma grande façanha de engenharia, com 77,1 quilômetros de comprimento, ligando o oceano Atlântico ao oceano Pacífico. Antes de sua existência, as embarcações tinham que viajar 20 mil quilômetros até contornar a extremidade sul da América do Sul. Este projeto monumental foi concluído em 10 anos a um custo aproximado de \$387.000.000,00 (NAVARRO, 2015).

Percebemos que ambas as construções se constituem empreendimentos marítimos com características de projetos, ou seja, utilizaram alguma técnica de planejamento, execução e acompanhamento, com especificidades únicas, diferenciadas, temporárias, e com o emprego de recursos financeiros, de pessoas e a aplicação de materiais com tecnologias da época.

Embora as práticas de projetos estejam presentes na história da humanidade desde tempos tão antigos, foi somente em 1697 que surgiu a primeira literatura que descreveu o gerenciamento de projetos, na obra Um Ensaio sobre Projetos, em sua primeira versão, escrita pelo jornalista e escritor inglês Daniel Defoe (CLELAND, 2004).

Em tempos mais recentes, o artigo seminal de Gaddis (1959), chamou a atenção para o crescimento da comunidade de gerenciamento de projetos, destacando a importância do gerente de projetos em campos novos e em expansão em sua época, como o da eletrônica, engenharia nuclear, astronáutica, aviônica e criogenia.

Em 1968, David I. Cleland e William R. King publicaram o primeiro livro acadêmico sobre gerenciamento de projetos, sob o título Systems Analysis and Project Management, no contexto da então emergente abordagem sobre sistemas (CLELAND et al., 2006).

Segundo pesquisa publicada em editorial do International Journal of Project Management sobre a evolução de pesquisa em gerenciamento de projetos, conforme evidenciado pelos artigos publicados no próprio Journal, o número de citações de artigos em gerenciamento de projetos aumentou quase 20 vezes, em 20 
anos, no período de 1987 a 2007, refletindo o expressivo aumento do interesse em gerenciamento de projetos dentro da academia (TURNER, 2010).

Em seu início, a história do gerenciamento de projetos como uma nova disciplina, esteve muito associada aos projetos de informática e de construção de obras de grande porte. Na atualidade, contudo, é um corpo de conhecimentos aplicado à praticamente qualquer atividade humana (CODAS, 1987).

Em 1969 foi fundado o Project Management Institute (PMI), na Pensilvânia, EUA, com o objetivo de promover o desenvolvimento do gerenciamento de projetos. Diante da necessidade de consolidar o corpo de conhecimentos em gerenciamento de projetos, um grupo de fundadores do PMI editou um manual de implantação direcionado aos profissionais experientes de projeto, constituindo-se um documento básico de referência (CODAS, 1987).

Em 1983 o Project Management Institute publicou um relatório denominado ESA (Ethics, Standards and Accreditation - Ética, Padrões e credenciamento), o qual apresentou seis funções de gerenciamento de projetos: gerenciamento de escopo, custo, prazo, qualidade, recursos humanos e comunicações. Em 1987 o Project Management Institute publicou um padrão para o gerenciamento de projetos, na forma de artigo com o título Project Management Body of Knowledge. Neste documento foram adicionadas as áreas de conhecimento em gerenciamento de contrato/compras e em gerenciamento de riscos, totalizando nove áreas de conhecimento (WIDEMAN, 1987). Posteriormente, este padrão foi reestruturado e publicado em 1996, como a primeira versão do Guia de Conhecimento em Gerenciamento de Projetos (Guia PMBOK), tendo sido reconhecido em 1999 pelo American National Standards Institute (ANSI) como um padrão para o gerenciamento de projetos. Edições revisadas do guia foram publicadas em 2000, 2004, 2008 e 2013, mantendo a estrutura básica de 1996 (DINSMORE et al., 2014). O guia encontra-se hoje em sua quinta edição, mantendo o propósito de continuar divulgando o corpo de conhecimentos em gerenciamentos de projetos amplamente reconhecido como boas práticas (PMI, 2013, p.1).

A seguir, são apresentadas definições do corpo de gerenciamento de projetos em linha com o Guia PMBOK (PMI, 2013), com definições complementares oriundas de outras fontes de reconhecimento acadêmico e profissional. 


\subsection{3}

\section{O que é um projeto?}

Projeto é um esforço temporário empreendido para criar um produto, serviço ou resultado único. A sua natureza temporária indica um início e um término definidos. O término é alcançado quando os objetivos tiverem sido atingidos ou quando se concluir que esses objetivos não serão ou não poderão ser atingidos e o projeto for encerrado, ou quando o mesmo não for mais necessário (PMI, 2013, p. 417).

O termo temporário não significa necessariamente de curta duração, mas está relacionado com o engajamento do projeto e sua longevidade, com a natureza exclusiva dos projetos.

Um projeto trata-se de um empreendimento com objetivo identificável, o qual consome recursos e opera sob restrições de escopo, tempo, custo e qualidade. Além do mais, projetos são considerados atividades exclusivas de uma empresa. O desafio para a empresa que não quer ser apenas mais uma no mercado, consiste em realizar atividades nunca realizadas antes e que também não se repetirão no futuro (KERZNER, 2002, p.17).

Assim, um projeto tem o propósito de atingir um determinado objetivo por meio da criação de um novo produto, serviço, ou resultado único, em um período de tempo planejado e determinado, dentro de um orçamento definido e em conformidade com as especificações, seguindo-se uma organização baseada em tarefas de duração finita (GADDIS, 1959).

Projetos podem ser vistos como os meios pelos quais as organizações implementam as mudanças benéficas que estão implícitas em seus objetivos organizacionais estratégicos (GÖRÖG, 2006).

Considerando a relevância que os projetos desempenham nas organizações contemporâneas, o gerenciamento de projetos se faz cada vez mais importante. Deste modo, apresenta-se a seguir uma abordagem teórica concernente a este tópico. 


\subsection{4}

\section{O que é gerenciamento de projetos?}

Diversas instituições em todo o mundo se propõem a disseminar o conhecimento em gerenciamento de projetos, conforme demonstrado no quadro 1. No Brasil, nos Estados Unidos, e em muitos outros países, o Project Management Institute (PMI) é a organização que têm obtido maior destaque como associação com este propósito. No entanto, outras instituições, como o Office of Government Commerce (OGC), e o International Project Management Association (IPMA), possuem maior expressividade em determinados países.

Independente da instituição predominante, contudo, todas as instituições têm contribuições significativas para o estudo e o avanço do conhecimento na área de gerenciamento de projetos.

Quadro 1: Principais associações de gerenciamento de projetos.

\begin{tabular}{|l|l|c|l|}
\hline \multicolumn{1}{|c|}{ INSTITUTO } & CONJUNTO DE MÉTODOS & ORIGEM & FOCO DA METODOLOGIA \\
\hline $\begin{array}{l}\text { Project Management } \\
\text { Institute (PMI) }\end{array}$ & $\begin{array}{l}\text { Project Management Body of } \\
\text { Knowledge (PMBOK) }\end{array}$ & EUA & Gestão geral de projetos \\
\hline $\begin{array}{l}\text { International Project } \\
\text { Management Association } \\
\text { (IPMA) }\end{array}$ & $\begin{array}{l}\text { IPMA competence baseline } \\
\text { version 3.0 (ICB) }\end{array}$ & Sede Suiça & Gestão geral de projetos \\
\hline $\begin{array}{l}\text { Office of Government } \\
\text { Commerce (OGC) }\end{array}$ & $\begin{array}{l}\text { Projects In Controlled } \\
\text { Environments (PRINCE2) }\end{array}$ & Reino Unido & $\begin{array}{l}\text { Gestão de projetos de sistemas de } \\
\text { informação }\end{array}$ \\
\hline $\begin{array}{l}\text { Australian Institute of } \\
\text { Project Management } \\
\text { (AIPM) }\end{array}$ & $\begin{array}{l}\text { Professional Competency } \\
\text { Standards for Project } \\
\text { Management (AIPM) }\end{array}$ & Austrália & Gestão geral de projetos \\
\hline $\begin{array}{l}\text { Association for Project } \\
\text { Management (APM) }\end{array}$ & APM Body of Knowledge & Reino Unido & Gestão geral de projetos \\
\hline $\begin{array}{l}\text { Japan Project Management } \\
\text { Forum (JPMF) }\end{array}$ & $\begin{array}{l}\text { ENAA Model Form- } \\
\text { International Contract for } \\
\text { Process Plant Construction }\end{array}$ & $\begin{array}{l}\text { Gestão de projetos de } \\
\text { construções }\end{array}$ \\
\hline
\end{tabular}

Fonte: PATAH e CARVALHO (2012, p. 6).

Segundo o Guia PMBOK (PMI, 2013), o gerenciamento de projetos pode ser compreendido como a aplicação de um conjunto de conhecimentos, habilidades, ferramentas e técnicas às atividades do projeto para atender aos requisitos do projeto. O Guia PMBOK (PMI, 2013) descreve quarenta e sete processos de gerenciamento de projetos, agrupados em cinco grupos, e distribuídos em dez áreas de conhecimento. É através da aplicação e integração destes processos que o gerenciamento de projetos efetivamente é realizado. Os 
processos de gerenciamento de projetos são agrupados nos grupos de processos e áreas de conhecimentos descritos a seguir.

Grupos de Processos:

- Iniciação

- Planejamento

- Execução

- Monitoramento e controle

- Encerramento

Áreas de Conhecimento:

- Gerenciamento de Integração

- Gerenciamento do escopo

- Gerenciamento do tempo

- Gerenciamento dos custos

- Gerenciamento da qualidade

- Gerenciamento dos recursos humanos

- Gerenciamento das comunicações

- Gerenciamento dos riscos

- Gerenciamento das aquisições

- Gerenciamento das partes interessadas

A seguir, é demonstrado na figura 1 como os grupos de processos interagem durante o ciclo de vida de um projeto, ao passo que o quadro 2 demonstra o relacionamento entre os grupos de processos e as áreas de conhecimento. 


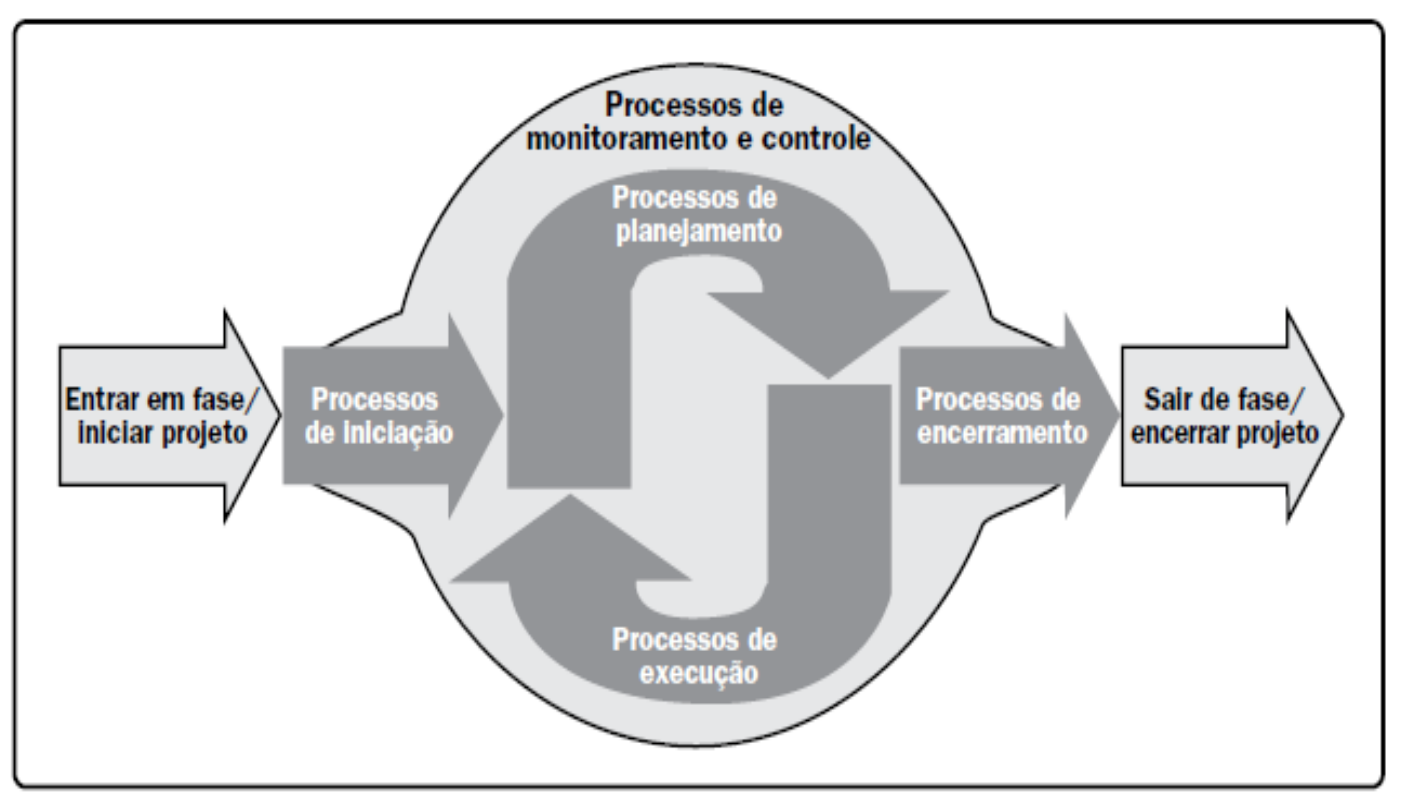

Figura 1: Grupos de processos de gerenciamento de projetos.

Fonte: Guia PMBOK (PMI, 2013, p. 50). 
Quadro 2: Grupo de processos de gerenciamento de projetos e mapeamento das áreas de conhecimento.

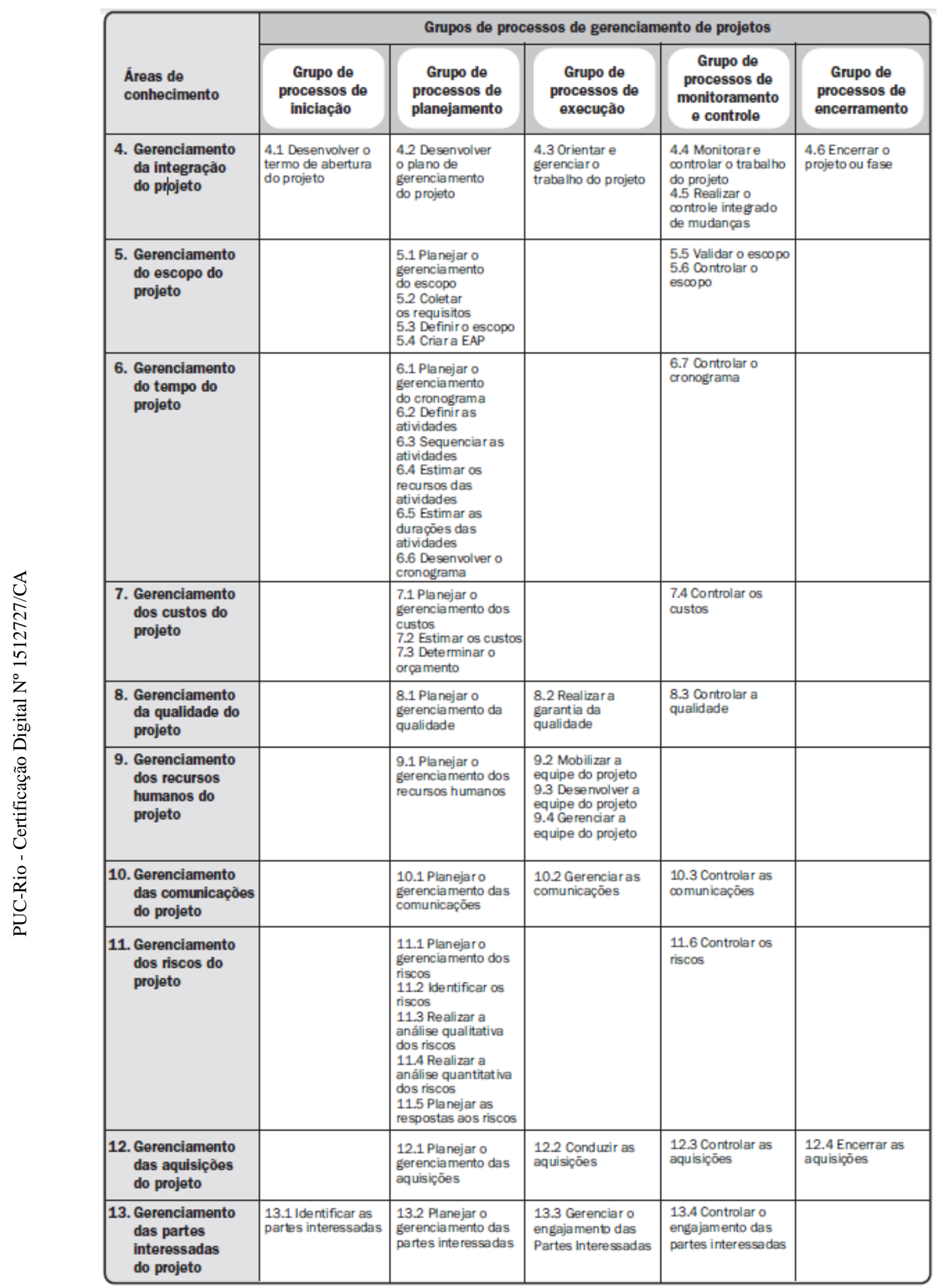

Fonte: Guia PMBOK (PMI, 2013, p. 423). 
Um projeto não necessariamente utiliza sempre os quarenta e sete processos identificados no modelo proposto pelo Guia PMBOK (PMI, 2013), cabe à equipe de gerenciamento de projetos selecionar os processos que são pertinentes e aplicáveis à cada momento do seu projeto. Também é comum que grandes projetos sejam divididos em fases. Nestes casos, os processos de um grupo de processos consistem de atividades que podem ser executadas e ocorrer novamente em cada fase de um projeto assim como para o projeto como um todo. Em projetos de implementação do ERP SAP, por exemplo, desde 1997 a SAP recomenda a utilização da metodologia ASAP, a qual é composta de 5 fases: Project Preparation, Blueprint, Realization, Final Preparation e Go Live e Support (GULLEDGE et al., 2005). Os processos de gerenciamento de projetos podem ser aplicados em todo o projeto de implementação do $E R P$, e podem ser aplicados também em cada uma das fases previstas na metodologia ASAP.

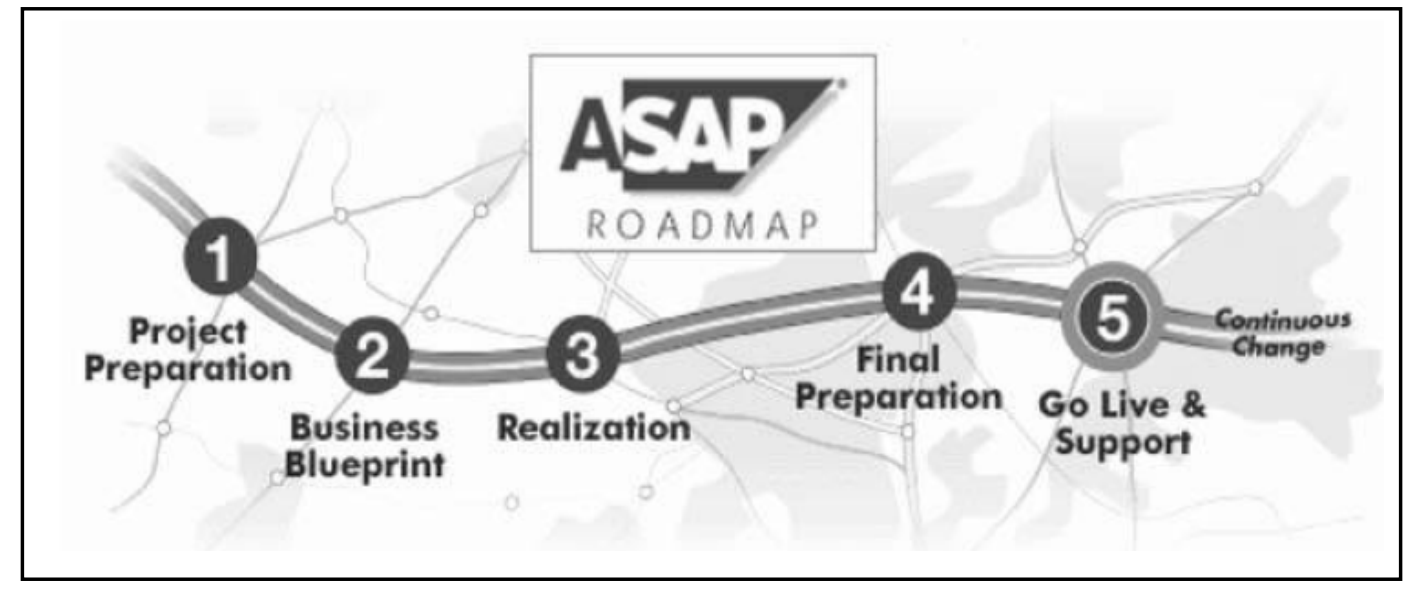

Figura 2: Metodologia ASAP SAP.

Fonte: GULLEDGE et al. (2005, p. 4).

\subsection{5}

\section{Processos de gerenciamento de projetos}

Um processo é um conjunto de ações e atividades inter-relacionadas que são executadas para criar um produto, serviço, ou resultado pré-especificado (PMI, 2013).

Os processos de gerenciamento de projetos garantem o fluxo eficaz do projeto ao longo de sua existência. O Guia PMBOK (PMI, 2013) descreve somente os processos de gerenciamento de projetos. 


\subsection{6}

\section{Áreas de conhecimento em gerenciamento de projetos}

Em uma economia onde a única certeza que se pode ter é a incerteza, somente o conhecimento constitui-se fonte segura de vantagem competitiva para as organizações (NONAKA, 2000).

Thomas e Mullaly (2006), destacaram a importância da capacidade organizacional em gerenciamento de projetos para a geração de valor. A maturidade em gerenciamento de projetos possibilita as organizações a concretizarem os benefícios esperados dos projetos (SHI, 2011). Partindo-se do pressuposto de que o conhecimento é um recurso de valor que pode ser criado e recriado, as organizações devem atentar para importância de que a gestão apropriada do conhecimento em gerenciamento de projetos é não somente relevante para o sucesso dos projetos organizacionais, mas ao passo que este conhecimento é internalizado, cristaliza-se em um ativo organizacional que permanece agregando valor à empresa.

Para se atingir este objetivo, entretanto, é importante haver a capacidade de se entender e aplicar o conhecimento em gerenciamento de projetos. Michael Polanyi (1966) afirmou que o conhecimento reside na nossa habilidade de usá-lo. O gerenciamento de projetos é um saber que precisa ser disseminado na organização, e internalizado pelos indivíduos, transformando conhecimento explícito em conhecimento tácito. Conforme Balbinot e Borim-De-Souza (2012) afirmaram, o conhecimento se refere a informações que podem ser contextualizadas por aqueles com a capacidade de compreender, validar e aplicála.

Dentro do escopo de estudos em gerenciamentos de projetos, uma área de conhecimento representa um conjunto de conceitos, termos e atividades que compõem o campo de estudo especializado em gerenciamento de projetos (PMI, 2013). As equipes de projetos devem utilizar esses conhecimentos com o propósito de aumentarem as chances de sucesso nos projetos em que atuam.

O Guia PMBOK (PMI, 2013) apresenta um corpo de conhecimentos em gerenciamentos de projetos agrupados em 10 áreas diferentes, as quais são apresentadas em mais detalhes a seguir. 


\section{- Gerenciamento de integração do projeto}

A área de conhecimento denominada gerenciamento de integração do projeto agrupa os processos e atividades que tem o objetivo de identificar, definir, combinar, unificar e coordenar os diversos processos existentes no gerenciamento de um projeto (PMI, 2013, p. 63). Esta área de conhecimento trata da coordenação de todos os aspectos do plano do projeto e envolve um elevado nível de interação (HELDMAN, 2009). O gerenciamento o projeto terá conseguido sincronizar os esforços do projeto quando integrar adequadamente os demais processos de gerenciamento (DINSMORE et al., 2014). E a comunicação contribui significativamente em cada um dos processos desenvolvidos nesta área de conhecimento.

\section{- Gerenciamento do escopo do projeto}

O gerenciamento do escopo do projeto inclui os processos necessários para garantir que o projeto contemple todo o trabalho necessário, e apenas o necessário, para se atingir os objetivos propostos pelo projeto (PMI, 2013, p.105). A definição e controle do escopo precisam ser continuamente examinados em todas as fases para minimizar os riscos do projeto (DINSMORE et al., 2014). Desde a primeira versão do Guia PMBOK (PMI, 2013), o escopo se apresenta como uma das restrições mais críticas a ser gerenciada para que o projeto alcance o sucesso. A comunicação desempenha um papel importantíssimo na gestão do escopo do projeto. Não somente a equipe de gestão, mas todo o time do projeto precisa compreender claramente o que está e o que não está contido no escopo do projeto. Toda mudança de escopo implica em impacto em outras restrições do projeto, tais como custo, qualidade, ou até mesmo na satisfação dos usuários do produto, serviço ou resultado exclusivo entregue pelo projeto.

\section{- Gerenciamento do tempo do projeto}

O gerenciamento do tempo do projeto inclui os processos necessários para gerenciar o término pontual do projeto (PMI, 2013, p. 141). Nesta área de conhecimento estão as atividades relacionadas com o cronograma do projeto. A 
equipe do projeto espera ser comunicada de forma clara sobre as atividades que precisam ser realizadas, e em quanto tempo devem ser concluídas, tendo visibilidade do caminho a ser seguido durante o projeto.

\section{- Gerenciamento dos custos do projeto}

Esta área de conhecimento inclui os processos envolvidos em planejamento, estimativas, orçamentos, financiamentos, gestão e controle dos custos, com o propósito de terminar o projeto dentro do orçamento previsto (PMI, 2013, p.193). O gerenciamento de custos do projeto é uma área com o potencial de gerar muita discórdia, contudo, quando bem executado pode ser base para um relacionamento harmonioso entre as partes interessadas (DINSMORE et al., 2014).

\section{- Gerenciamento da qualidade do projeto}

O gerenciamento da qualidade do projeto inclui os processos e as atividades da organização executora que determinam as políticas de qualidade, os objetivos e as responsabilidades, de modo que o projeto satisfaça as necessidades para as quais foi empreendido. Esta área de conhecimento se propõe a garantir que os requisitos do projeto, incluindo os requisitos do produto, sejam cumpridos e validados (PMI, 2013, p. 227).

\section{- Gerenciamento dos recursos humanos do projeto}

O gerenciamento dos recursos humanos do projeto inclui os processos que organizam, gerenciam e guiam a equipe do projeto. Esta área de conhecimento contempla os conhecimentos pertinentes à gestão dos indivíduos da equipe, incluindo atividades como a definição de papéis e responsabilidades, relações hierárquicas, mobilização das pessoas, interação da equipe, acompanhamento do desempenho dos indivíduos, feedback, resolução de problemas e a gestão de mudanças (PMI, 2013, p. 255). A sinergia e o engajamento da equipe são peças fundamentais para que o projeto alcance os objetivos pretendidos. 


\section{- Gerenciamento dos riscos do projeto}

O gerenciamento dos riscos do projeto inclui os processos de planejamento, identificação, análise, planejamento de respostas e controle de riscos de um projeto. Os objetivos de gerenciamento dos riscos do projeto são aumentar a probabilidade e o impacto dos eventos positivos e reduzir a probabilidade e o impacto dos eventos negativos do projeto (PMI, 2013, p. 309).

\section{- Gerenciamento das aquisições do projeto}

O gerenciamento das aquisições do projeto abrange os processos necessários para comprar ou adquirir produtos, serviços, ou resultados externos à equipe do projeto. Esta área fornece conhecimentos que tem por objetivo auxiliar nas atividades relacionadas com a gestão dos contratos, com o processo e as decisões de compras, com a seleção de fornecedores, e todas as demais atividades associadas às aquisições necessárias para o projeto (PMI, 2013, p. 355).

\section{- Gerenciamento das partes interessadas do projeto}

O gerenciamento das partes interessadas do projeto inclui os processos exigidos para identificar todas as pessoas, grupos ou organizações que podem impactar ou serem impactados pelo projeto, analisar as expectativas das partes interessadas e seu impacto no projeto, e desenvolver estratégias de gerenciamento apropriadas para o engajamento eficaz das partes interessadas nas decisões e execução do projeto (PMI, 2013, p. 391).

\section{- Gerenciamento das comunicações do projeto}

Segundo o Guia PMBOK (PMI, 2013, p. 287), o gerenciamento das comunicações do projeto inclui os processos necessários para assegurar que as informações do projeto sejam planejadas, coletadas, criadas, distribuídas, armazenadas, recuperadas, gerenciadas, controladas, monitoradas e finalmente dispostas de maneira oportuna e apropriada. Os gerentes de projetos passam a maior parte do tempo se comunicando com os membros da equipe e outras partes 
interessadas do projeto, quer sejam internas (em todos os níveis da organização) ou externas a organização. A comunicação eficaz cria uma ponte entre as diversas partes interessadas do projeto, que podem ter diferenças culturais e organizacionais, diferentes níveis de conhecimento, e diversas perspectivas e interesses que podem impactar ou influenciar a execução ou resultado do projeto.

No gerenciamento de projetos, poucas questões têm tanto impacto sobre os resultados do projeto quanto o desempenho da equipe funcional. As equipes de alto desempenho normalmente geram resultados superiores, portanto, compreender como facilitar comportamentos de uma equipe eficaz é fundamental para o sucesso do projeto. Embora não seja tarefa fácil identificar e replicar os comportamentos que diferenciam as equipes de alto e baixo desempenho, há diversas pesquisas que apontam para a existência do relacionamento entre a comunicação e o desempenho do time do projeto (KENNEDY et al., 2011).

Para Dinsmore et al. (2014), entregar um sólido plano de gerenciamento de comunicação para todos os membros da equipe, patrocinadores e participantes (incluindo o cliente) é a chave para o sucesso de um projeto. A distribuição da informação do projeto é fundamental para garantir que toda a informação seja dada no devido tempo ao longo de todas as fases do projeto. O gerente do projeto deve ter a adesão da equipe antes de prosseguir com o plano e todos devem cumpri-lo rigorosamente para assegurar o sucesso do projeto.

O Guia PMBOK (PMI, 2013) apresenta os processos de cada área de conhecimento em um modelo esquemático de entradas, ferramentas e técnicas de transformação, e saídas. Para o gerenciamento de comunicações do projeto o Guia PMBOK (PMI, 2013) compreende três processos específicos:

- Planejar o gerenciamento das comunicações

- Gerenciar as comunicações

- Controlar as comunicações

Uma visão geral desses três processos é apresentada na figura 3: 


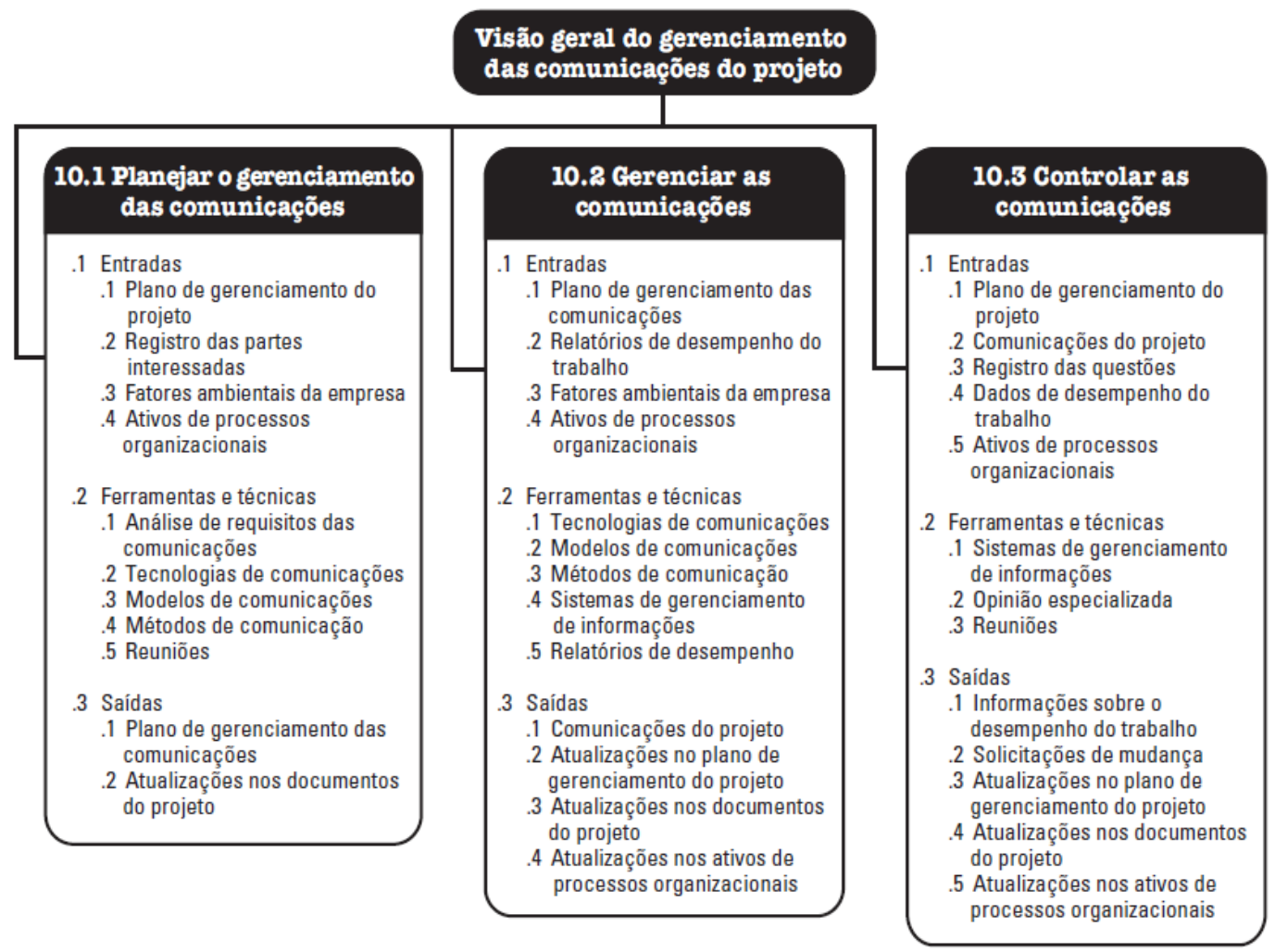

Figura 3: Visão geral do gerenciamento das comunicações do projeto.

Fonte: Guia PMBOK (PMI, 2013, p. 287).

O Guia PMBOK (PMI, 2013) realiza um detalhamento destes três processos, com uma visão positivista, conforme apresenta-se a seguir:

I. Planejar o gerenciamento das comunicações

O plano de gerenciamento do projeto é mencionado como um importante documento a ser levando em consideração, por fornecer informações relevantes para o planejamento da comunicação, pois, ele contém não somente as diretrizes bases do projeto, mas ele relaciona a comunicação com outros processos do gerenciamento do projeto que contém as informações que serão de interesse das partes interessadas, tais como os organogramas, organização do projeto, relações de responsabilidade das partes interessadas, logísticas dos participantes do projeto, só para citar alguns exemplos.

O registro das partes interessadas é igualmente apontado como um importante documento no planejamento das comunicações, pois, ele contém informações das pessoas que de alguma forma são impactadas pelo projeto, incluindo tanto informações de identificação, como nome e posição na 
organização, quanto informações de avaliação e classificação das pessoas interessadas em relação à mudança provocada pelo projeto, tal como suas expectativas, potenciais influências no projeto, fase de maior interesse no ciclo de vida, se tendem a serem resistentes, neutras ou apoiadoras do projeto. Tais preocupações são consideradas essenciais para o planejamento adequado da comunicação do projeto. Na análise destas informações, o Guia PMBOK (PMI, 2013) sugere a possibilidade de se utilizar como indicador de complexidade das comunicações no projeto, o número de canais ou caminhos de comunicação em potencial, através da fórmula $n(n-1) / 2$, onde “ $n$ ” representa o número de partes interessadas. Por exemplo, um projeto com 10 partes interessadas tem 10 (10 - 1) / 2 = 45 canais de comunicação em potencial.

De acordo com o Guia PMBOK (PMI, 2013, p.291), também devem ser considerados os fatores ambientais, uma vez que as comunicações precisam ser adaptadas ao ambiente do projeto e da organização. Estes fatores ambientais podem incluir:

- Cultura, estrutura e governança organizacional;

- Distribuição geográfica das instalações e dos recursos;

- Normas, tais como, códigos de conduta e padrões de qualidade;

- Infraestrutura, como os equipamentos e instalações existentes;

- Recursos humanos existentes, incluindo suas habilidades e conhecimentos;

- Administração de pessoal, incluindo análises de desempenho;

- Condições do mercado;

- Tolerância a riscos das partes interessadas;

- Canais de comunicação estabelecidos na organização; e

- Sistemas de informações do gerenciamento de projetos.

Ativos de processos organizacionais também devem ser levados em consideração no planejamento das comunicações. Estes ativos se constituem dos planos, processos, políticas, procedimentos e as bases de conhecimento corporativa específicas da organização e por ela utilizados. Eles incluem qualquer artefato, prática ou conhecimento de qualquer uma das organizações envolvidas 
no projeto que possam ser usados para execução ou administração do projeto (PMI, 2013, p. 28). Dentre estes, as lições aprendidas e as informações históricas, as quais resgatam os resultados de decisões em projetos anteriores semelhantes, são particularmente importantes porque podem ampliar a visão para as decisões relacionadas com a comunicação no projeto atual (PMI, 2013, p. 291).

Um modelo básico de comunicação é apresentado pelo guia, conforme demonstrado na figura 4, enfatizando-se que há muitos desafios para estabelecer uma comunicação eficaz com as partes interessadas do projeto. Por exemplo, um membro da equipe altamente técnico pode ter dificuldades em comunicar com êxito um conceito técnico para outro membro da equipe, em um ambiente dificultado pela distância, pode fazer com que o significado da mensagem seja mal interpretado ou mal-entendido (PMI, 2013, p. 294).

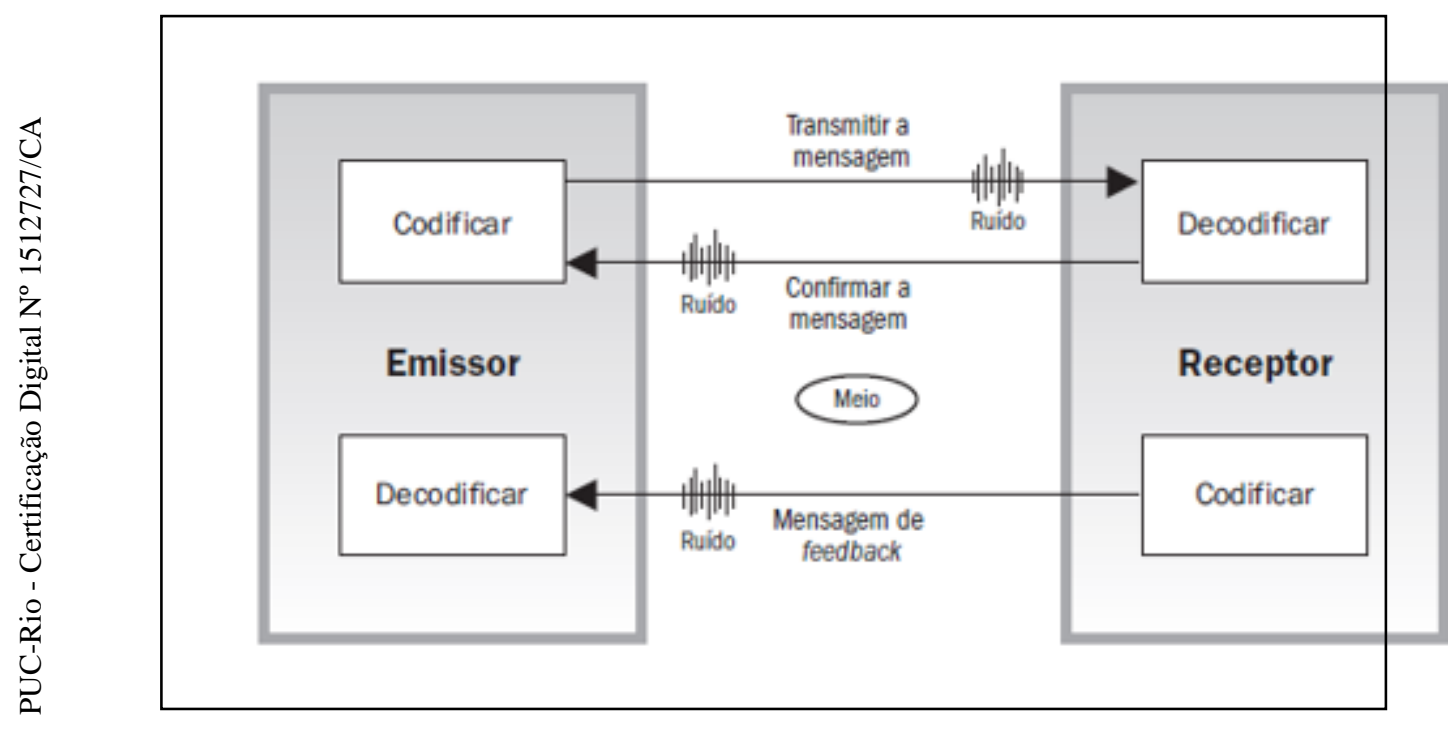

Figura 4: Modelo Básico de Comunicação. Fonte: Guia PMBOK (PMI, 2013, p. 294).

Os resultados do processo planejar o gerenciamento de comunicações são o plano de gerenciamento das comunicações e a atualização dos documentos do projeto, contendo informações tais como o cronograma e o registro das partes interessadas. 


\section{Gerenciar as comunicações}

Utilizando os ativos de processos organizacionais, os fatores ambientais mapeados, o plano de gerenciamento das comunicações resultante do planejamento das comunicações do projeto, e os relatórios de desempenho do trabalho, o processo de gerenciar as comunicações se propõe a facilitar um fluxo de comunicação eficiente e eficaz entre as partes interessadas durante a execução do projeto.

Os relatórios de desempenho são considerados importantes para a comunicação do projeto no sentido de darem visibilidade quanto ao status do projeto aos diferentes públicos identificados. Relatar o desempenho é compreendido como a ação de coletar e distribuir informações relativas ao desempenho, incluindo relatórios de andamento, medições do progresso e previsões. Relatar o desempenho envolve a coleta e a análise periódica da linha de base em relação aos dados reais para entender e comunicar o andamento e o desempenho do projeto, assim como para prever os resultados do projeto. Os relatórios de desempenho precisam fornecer informações no nível adequado para cada público (PMI, 2013, p. 301).

Além de contribuir para uma comunicação adequada, o processo de gerenciar as comunicações se propõe ainda a entregar atualizações no plano de gerenciamento do projeto, nos documentos do projeto e nos ativos de processos organizacionais.

A atualização no plano de gerenciamento do projeto envolve atualizar as linhas de base do projeto com base no desempenho atual. A linha de base de medição compara a execução do projeto com o planejamento e apresenta a medição dos desvios para controle gerencial, integrando informações pertinentes ao escopo, cronograma, custos do projeto, além de parâmetros técnicos e de qualidade (PMI, 2013, p. 302).

Os documentos do projeto atualizados incluem os cronogramas, registro de questões, além dos requisitos de recursos financeiros do projeto.

Os ativos de processos organizacionais atualizados incluem: notificações das partes interessadas sobre questões solucionadas, mudanças aprovadas e a situação geral do projeto; relatórios do projeto; apresentações do projeto; registros 
do projeto como as atas de reunião; feedback das partes interessadas em relação às operações do projeto; além da documentação das lições aprendidas.

\section{Controlar as comunicações}

Controlar as comunicações é definido pelo Guia PMBOK (PMI, 2013, p. 303) como o processo de monitorar e controlar as comunicações no decorrer de todo o ciclo de vida do projeto para assegurar que as necessidades de informação das partes interessadas do projeto sejam atendidas. O principal benefício deste processo é a garantia de um fluxo ótimo de informações entre todos os participantes das comunicações, em qualquer momento. $\mathrm{O}$ impacto e as repercussões das comunicações do projeto devem ser cuidadosamente avaliados e controlados para assegurar que a mensagem correta seja entregue à audiência correta, no tempo certo.

Este processo destaca a importância do registro de questões do projeto. O registro de questões é usado para documentar e monitorar a solução para as questões do projeto. Ele pode ser usado para facilitar a comunicação e garantir um entendimento comum das questões. Um registro por escrito documenta e ajuda a monitorar quem é responsável para resolução de questões específicas até um prazo definido. A resolução de questões aborda obstáculos que podem bloquear a equipe e impedir que ela alcance suas metas. Essas informações são importantes porque fornecem um repositório para o que já aconteceu no projeto e uma plataforma para as comunicações subsequentes a serem entregues (PMI, 2013, p. 305).

Destaca-se também a importância da utilização de um sistema de gerenciamento das informações que auxilie o gerente de projetos na coleta e distribuição das informações para as partes interessadas sobre os custos, o andamento do cronograma e o desempenho do projeto.

A opinião especializada também é relevante para avaliar o impacto das comunicações do projeto, a necessidade de ação ou intervenção, as ações que devem ser tomadas, a responsabilidade pela tomada de tais ações e o período de tempo para a tomada das ações.

Também as reuniões são facilitadoras no processo de controlar as comunicações, pois, este processo requer a discussão e o diálogo com a equipe do 
projeto para determinar a maneira mais apropriada de atualizar e comunicar o desempenho e responder às solicitações de informações das partes interessadas.

Este processo frequentemente resulta na necessidade de ajuste, ação e intervenção. Em consequência, solicitações de mudança serão geradas como um resultado (PMI, 2013, p. 307).

Assim, considerando-se a relevância da comunicação nos projetos, conforme explicitado pelas fontes e autores referenciados neste capítulo, o tópico a seguir prossegue com abordagens da comunicação organizacional em um contexto mais amplo, das quais, na opinião do autor do presente trabalho, emanam contribuições para o gerenciamento de projetos.

\section{2}

\section{Comunicação Organizacional}

O interesse na comunicação está profusamente presente tanto no estudo acadêmico das organizações, quanto nas práticas organizacionais. Tamanha é sua disseminação, que o próprio termo comunicação tem sido abordado com diferentes significados ao longo do tempo.

Segundo Putnam et al. (2004, p. 77):

“Os teóricos organizacionais clássicos equipararam a comunicação aos documentos escritos e à autoridade de comando, ao fluxo ascendente das mensagens e ao ato de persuadir os trabalhadores, ao fluxo horizontal de informação, à comunicação informal e ao ouvir, ao feedback e ao comportamento circular, às premissas de decisão e aos canais formais de comunicação. Os teóricos organizacionais contemporâneos tratam comunicação como sinônimo de constructos, tais como processamento de informação, redes sociais, coordenação e participação. Assim, comunicação tornou-se uma espécie de curinga, um termo que impregna a maioria dos tópicos nos estudos organizacionais”.

Considerando o interesse do presente estudo em analisar as práticas organizacionais acerca da comunicação em ambientes de projetos, com vistas a buscar as contribuições existentes no arcabouço teórico concernente a este tema para estas práticas organizacionais, descreve-se a seguir um breve histórico do desenvolvimento da comunicação organizacional, e subsequentemente se discorre sobre a comunicação sob diferentes perspectivas. 


\subsection{1}

\section{História e desenvolvimento da comunicação organizacional}

Para Kunsch (2008), a forma como nós compreendemos comunicação organizacional nos dias de hoje tem suas raízes no período da Revolução Industrial. São incomensuráveis as mudanças provocadas pelo crescimento organizacional após a Revolução Industrial. A partir deste período a comunicação começa a ser percebida com maior relevância dentro das organizações. Inicia-se um período de profissionalização do gerenciamento da comunicação organizacional e essa passa a ser considerada uma área estratégica em muitas organizações.

Os trabalhos em comunicação organizacional mais recentes foram influenciados pela comunicação empresarial e industrial das décadas de 20 a 50 e pela escola de recursos humanos das décadas de 50 a 70. Os textos do período focavam as estratégias de persuasão utilizadas pelo alto nível executivo. Nas décadas de 60 a 70 o foco migrou para a pesquisa das transmissões das mensagens dentro das organizações. Neste período, as pesquisas estavam interessadas em analisar a influência da comunicação na performance dos indivíduos e das organizações. Os interesses predominantes focalizavam em aumentar a eficiência na comunicação dos indivíduos em seu trabalho e a comunicação em todo o sistema. Estudos sociológicos sobre a relação superior e subordinado, sobre as redes de comunicação e sobre novas tecnologias de comunicação, também estavam presentes nas pesquisas deste período de orientação modernista (PUTNAM et al., 2004).

Neste período, organização e comunicação eram compreendidas como realidades concretas, objetivas e manipuláveis, vistas pela ótica de um modelo mental racionalista e instrumental. Deste modelo emanaram os entendimentos que dividiam os diferentes níveis hierárquicos, distribuídos de forma objetiva em unidades organizacionais de uma estrutura empresarial (KUNSCH, 2008).

No início da década de 80, contudo, houve uma revolução nos estudos acadêmicos de comunicação organizacional, em consonância com a mudança que estava ocorrendo no campo geral do estudo das organizações. A comunicação passou a ser compreendida não somente como o estudo das mensagens, mas da significação e da interação simbólica que constitui as organizações. Novos estudos 
surgiram nas pesquisas de comunicação organizacional, com foco no sentido dos eventos organizacionais, na ambiguidade estratégica, nas linguagens, símbolos e cultura organizacional, na identificação organizacional e no controle não obstrutivo, nas regras e nos scripts da comunicação, no discurso público corporativo, no exercício do poder e controle por meio da comunicação distorcida (PUTNAM et al., 2004).

Este panorama nos fornece um breve quadro da evolução organizacional. Confluente com este breve apanhado histórico, o próximo tópico discorre sobre as principais correntes de pensamento em comunicação, partindo-se da tipologia de paradigmas em ciências sociais concebida por Burrell e Morgan (1979).

\subsection{2}

\section{Visões paradigmáticas da comunicação organizacional}

Neste tópico, primeiramente será apresentado o modelo de análise das teorias sociais proposto por Burrell e Morgan (1979). Em seguida, descreve-se sobre a comunicação organizacional influenciada por este modelo, concluindo-se com uma perspectiva da comunicação organizacional como constitutiva das organizações.

O modelo de Burrell e Morgan (1979) possui duas dimensões relativas às teorias em ciências sociais. A primeira dimensão engloba os paradigmas funcionalista e interpretativista, e a segunda dimensão contempla os paradigmas humanismo-radical e estruturalismo radical, conforme ilustrado pela figura 5 - Os quatro paradigmas em ciências sociais. 


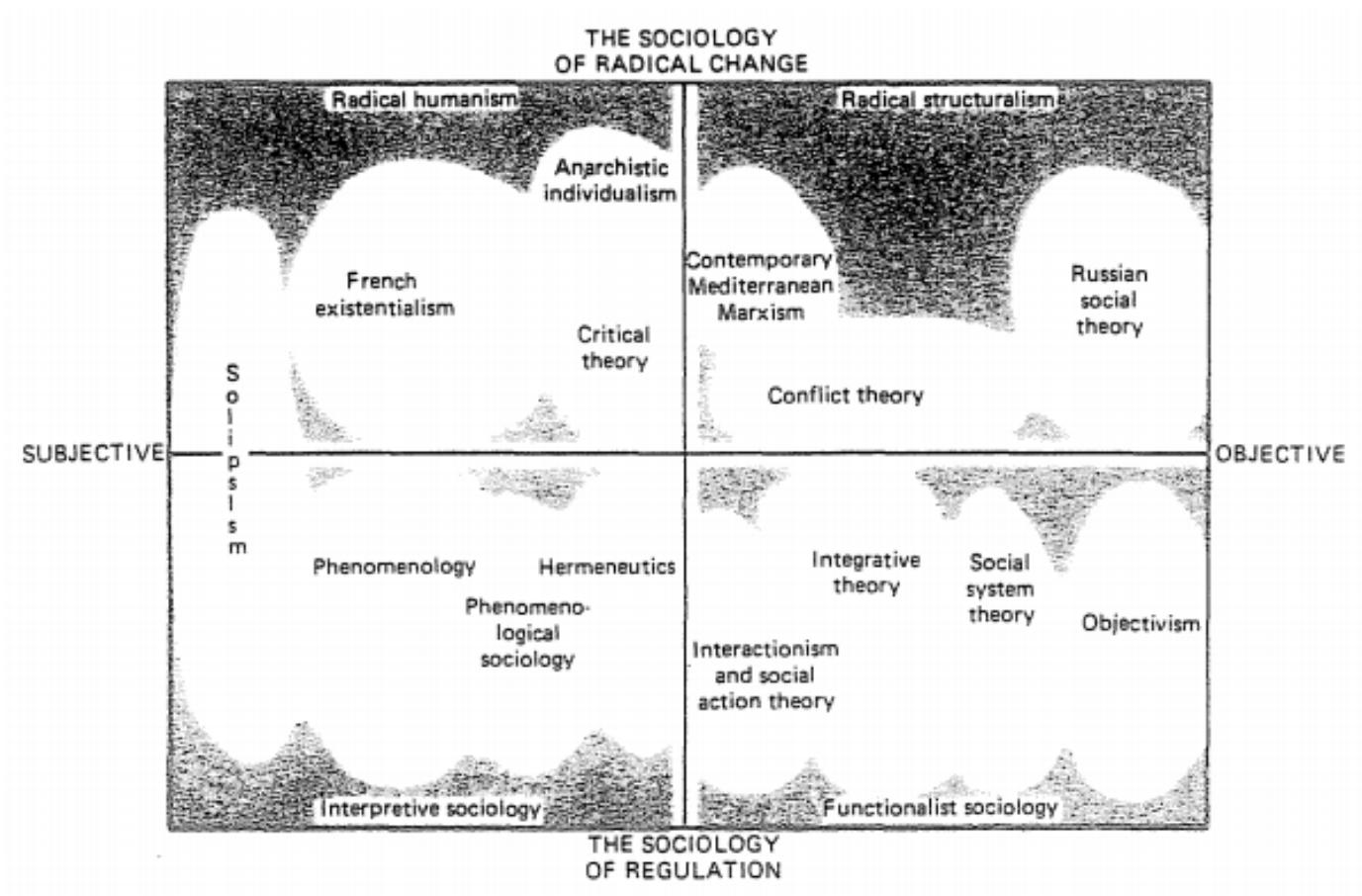

Figura 5: Os quatro paradigmas das ciências sociais.

Fonte: Burrell e Morgan (1979, p.29).

Para Burrell e Morgan (1979), há uma dimensão reguladora, dentro dos quais se posicionam o paradigma funcionalista e o paradigma interpretativista, ou seja, ambos partilham de uma visão da sociedade orientada para ordem. Contudo, estes dois paradigmas se opõem quanto às suas visões da realidade. O paradigma funcionalista tende a compreender a realidade sob uma ótica objetiva, enquanto no paradigma interpretativista a realidade é vista sob uma ótica subjetiva. Para os funcionalistas a realidade consiste em fatos concretos, os quais são externos ao indivíduo. Portanto, é na estrutura que o pesquisador deve concentrar-se buscando apreender seus elementos constituintes. Por outro lado, para os interpretativistas, a realidade social é como um processo simbólico criado por ações contínuas. Desta forma, organizações são entidades plurais criadas por seus membros, as quais para serem compreendidas devem ser investigadas por dentro (CASALI, 2004).

Contrastando estes paradigmas, o paradigma funcionalista caracteriza-se por uma visão objetiva da realidade social, uma epistemologia positivista, uma visão determinista da natureza humana e uma compreensão reguladora da sociedade. Abordagens funcionalistas partilham uma preocupação explicativa, pois, procuram produzir conhecimento 'útil'. Por 'útil' compreende-se a produção assertiva e generalizável constituída na forma de 'leis' que possibilitam a realização de previsões, da manutenção de controles e do gerenciamento de 
situações. Por outro lado, o paradigma interpretativo partilha a visão reguladora funcionalista da sociedade, mas diferencia-se deste na compreensão da natureza humana. A pesquisa interpretativa centra-se na documentação de processos e experiências através das quais as pessoas constroem a realidade organizacional. Para interpretativistas, conhecimento 'útil' é o que procura compreender o que está acontecendo em determinada situação, enquanto reconhece que qualquer depoimento do que está acontecendo depende do ponto de vista da pessoa pois nenhuma situação pode ser completamente compreendida a partir de um único ponto de vista (CASALI, 2004).

O funcionalismo e suas correntes afiliadas favorecem objetividade, pressupõem uma realidade concreta, buscam o que é observável, tentam descrever e explicar o mundo para prevê-lo e controlá-lo por meio de generalizações. Esta perspectiva é restrita pela sua insensibilidade ao papel da linguagem, pela sua falha em considerar a ambiguidade, que é parte da dinâmica situacional, e pelo fato de não apreciar como o fenômeno em estudo é modificado pelos próprios participantes ao longo da investigação. A pesquisa interpretativa supera as falácias funcionalistas centrando-se em significados, sendo sensível a ambiguidade inerente a linguagem, reconhecendo multiplicidade e dinamismo, bem como o contexto em que se situam pesquisadores e participantes da pesquisa. Entretanto, os esforços interpretativos são restritos pois não consideram relações de poder (CHENEY, 2000, apud CASALI, 2004), os quais serão foco dos paradigmas críticos.

Enquanto o funcionalismo e o interpretativismo são normalmente apresentados como opostos, as perspectivas radical-humanista e radicalestruturalista são geralmente reunidas sob o título de teoria crítica. Ambos paradigmas partilham a concepção de que a sociedade está em constante mudança embora partam de pontos de vista diferentes. O humanismo radical é subjetivo, preocupado com a emancipação individual; enquanto o estruturalismo radical é objetivo explorando forças sociais, políticas e econômicas que subjugam a ação individual. A visão das organizações como prisões psíquicas é um exemplo de abordagem humanista-radical, por outro lado a visão das organizações como instrumentos de dominação (MORGAN, 2013) ilustra o paradigma estruturalistaradical. 
Apesar de sua habilidade de oferecer perspectivas variantes das correntes de pensamento dominantes, abordagens críticas são condenadas pelo fato de pressuporem estabilidade, adoção de uma distância entre o sujeito e a pesquisa e supressão de significados (CHENEY, 2000, apud CASALI, 2004).

Qualquer tema pode ser estudado através dos paradigmas propostos por Burrell e Morgan (1979). Cada paradigma irá oferecer uma perspectiva diferente do fenômeno sob investigação gerando uma variedade de possibilidades de pesquisa. Diferentes concepções da comunicação organizacional demonstram como cada paradigma aborda este tema. Comunicação, por sua natureza polissêmica, é um campo bastante fértil para a multiplicidade de abordagens e interpretações. Cheney (2000, apud CASALI, 2004) salienta que cada perspectiva de pesquisa, com suas variantes e formas híbridas, tem seus próprios pontos obscuros, bem como capacidades de iluminação.

Putnam et al. (2004) cita Smith para apresentar três possíveis relacionamentos entre organização e comunicação: container, produção e equivalência. O relacionamento de contenção compreende a comunicação como algo localizado dentro de uma estrutura organizacional material, concretizada, reificada. Já o segundo tipo de relacionamento, o de produção, faz o escrutínio de como as organizações produzem a comunicação, ou como a comunicação produz a organização, ou ainda como ambas se produzem reciprocamente. Por último, o relacionamento de equivalência aborda a comunicação e organização como um mesmo fenômeno.

De acordo com Casali (2004) as noções de "comunicação nas organizações” (container) são predominantemente funcionalistas e “comunicação como organização” (produção e equivalência) como principalmente interpretativista. As perspectivas críticas englobam tanto as noções de comunicação “nas” e “como” organizações.

\subsection{3}

\section{Comunicação nas organização}

A conceitualização de comunicação nas organizações toma a comunicação como uma variável, um elemento das organizações, como alguma coisa que ocorre dentro da estrutura organizacional. Nesta perspectiva, a organização é uma 
entidade e tal compreensão percebe a organização a partir de uma atitude essencialista. A atitude essencialista toma a existência da organização como um fato dado e então coloca em questão como investigá-la cientificamente. O objetivo é chegar a uma teoria ou modelo de organização e sua meta final é a eficiência e eficácia administrativa (TAYLOR e VAN EVERY, 2000, apud CASALI, 2004).

Kunsch (2009) descreve que a comunicação se vista como um fenômeno distinto, a compreensão de 'organização’ é geralmente restrita a um 'local', ao passo que a concepção da 'comunicação' geralmente se restringe à interação social conceitualmente resumida em ações de transferência de informação.

Pesquisas abordando “comunicação nas organizações” enquadram-se melhor no paradigma funcionalista porque pressupõem uma visão objetiva das organizações. Dentro desta concepção, a organização é percebida como uma estrutura de base com prioridade sobre a ação social e a comunicação é uma de suas características. Deste ponto de vista, comunicação é um elemento do container organizacional, estudado de fora. O relacionamento container trata a comunicação como localizada dentro de uma estrutura organizacional reificada e ou materialista). Logo, os elementos estruturais-funcionais da comunicação são críticos para a manutenção da ordem organizacional (PUTNAM et al. 2004). Supõe-se que a comunicação sistematicamente reproduza as estruturas organizacionais e será ditada pelas necessidades organizacionais de ordem prática. A visão de que as organizações incluem comunicação é congruente com o caráter funcionalista regulador no qual a comunicação é uma função que sustenta o equilíbrio e a ordem dentro da organização (KUNSCH, 2009).

De acordo com Putnam (1982) o paradigma funcionalista é dominante tanto em teoria das organizações como em estudos de comunicação organizacional. Até a revolução crítico-interpretativista da década de 1980, tradições positivistas eram o modo de pesquisa dominante em comunicação organizacional. Na perspectiva funcionalista a organização é tipificada como uma máquina, um organismo ou um sistema cibernético. A comunicação nesta perspectiva é primariamente mecanicista, enfatizando a transmissão, os efeitos, a seleção de canais e o processamento de informação. Hospedada em um container físico, a comunicação segue padrões de transmissão característicos da hierarquia vertical e a da distância espacial entre os membros. Análises de redes permitem a emergência de estruturas de comunicação a partir da interação entre os membros 
organizacionais, mas a pesquisa é dominada mais pela forma do que pelo conteúdo ou significado da mensagem. Dentre suas diversas correntes de pensamento, estas pesquisas reificam tanto as organizações como a comunicação em imagens físicas, em uma realidade objetiva e na prática da pesquisa reguladora (CASALI, 2009).

Focada em características da comunicação tais como transmissão e representação, a visão de “comunicação nas organizações” é criticada não apenas por sua compreensão restrita da comunicação como uma variável organizacional, mas também em grande parte por seu viés gerencial (PUTNAM, 1982).

\subsection{4}

\section{Comunicação como organização}

Kunsch (2009, p. 69), salienta a importação de se ver a comunicação como organização e organização como comunicação. Este conceito engloba a compreensão da comunicação organizacional que foca no processo organizante realizado por meio de interações simbólicas. Este enfoque tem o interesse de produzir uma teoria da comunicação para explicar o fenômeno organizacional. Esta perspectiva inspira-se na noção de construção social da realidade e é uma resposta a falácia de reificação, onde as organizações são entidades em que a comunicação está situada. Ao contrário, nesta concepção as organizações são vistas como sistemas de indivíduos em interação os quais, por meio da comunicação, são ativamente envolvidos em processos de criação e recriação da sua particular ordem social.

A noção de “comunicação como organização" engloba duas formas de relacionamento entre comunicação e organizações: produção e equivalência. A relação de produção examina a forma como as organizações produzem comunicação, ou como a comunicação produz as organizações, ou ainda a coprodução de ambos. Fica então o dilema de quando um tem existência anterior ao outro, ou se comunicação e organização se desenvolvem concomitantemente. A relação de equivalência postula uma mudança ainda mais radical no padrão de relacionamento. Esta abordagem trata comunicação e organização como unidades monásticas ou como o mesmo fenômeno expresso de maneira diferente, isto é, 
comunicação é organização e organização é comunicação, os dois processos são isomórficos (PUTNAM et al., 2004).

Seguindo esta perspectiva, a comunicação é a substância de um processo organizante, onde, por meio de práticas discursivas, os membros das organizações se engajam na complexa construção de diversos sistemas de significados (MUMBY, 2000, apud CASALI, 2004). Desta forma, a noção de "comunicação como organização” segue a tradição interpretativista. Esta perspectiva se concentra no estudo de significados emergentes, os quais são revelados por meio de interações da vida cotidiana através da comunicação. No paradigma interpretativo, a realidade organizacional é socialmente construída por meio das ações desempenhadas e das palavras e símbolos utilizados pelos membros da organização. A realidade assim constituída é então ativamente mantida por meio de experiências comunicacionais e os significados emergentes são promulgados por meio destes comportamentos (PUTNAM, 1982).

O mundo social é percebido como interativo, dinâmico e emergente; assim como as organizações, esta é a proposição de base da noção de "comunicação como organização”. Esta noção concebe a organização como uma realidade social que emerge através da comunicação, ou como propõem Taylor e Cooren (1997, apud CASALI, 2004), as organizações emergem por meio da linguagem, por meio de enunciados e atos de linguagem. De acordo com Cheney (2000, apud CASALI, 2004), posicionamentos interpretativistas revertem a frase preposicional “comunicação nas organizações” para considerar as características organizacionais da comunicação, especialmente em termos da construção de uma 'voz' e autoridade por meio de linguagem. Desta forma é o uso da linguagem e o significado promulgado por mensagens verbais e não verbais que criam e sustentam a realidade social (PUTNAM, 1982).

Apesar de propor uma premissa inspiradora, a noção de “comunicação como organização” é carente de conexão com a realidade, ela falha em perceber a materialidade enfatizada pela noção de “comunicação nas organizações”. Afinal, o processo de comunicação não se restringe ao domínio subjetivo da linguagem, ele também possui manifestações objetivas. De fato, a existência de toda organização social humana caracteriza-se tanto por ser condicionada a comunicação, como por ser uma estrutura na qual a comunicação ocorre. As organizações não apenas 
constituem-se através da comunicação, mas também se expressam em comunicação (TAYLOR e COOREN, 1997, apud CASALI, 2004).

Para Kunsch (2008), o fato de as organizações serem compostas por pessoas que possuem os mais diferentes universos cognitivos e as mais diversas culturas e visões de mundo implica por si só a complexidade que é pensar a comunicação nas organizações ou as organizações como comunicação.

Sendo assim, Casali (2004) sugere a necessidade de um modelo de compreensão da comunicação organizacional mais abrangente, de forma a obter um melhor entendimento da dinâmica do mundo material e social.

Weick (2005) argumenta que as pessoas se organizam para dar sentido às ambiguidades e endereçam esse sentido de volta ao mundo para tornar esse mundo mais ordenado.

Influenciados pelos trabalhos de Karl Weick, muitos estudiosos têm postulado que a comunicação é a essência da organização, tratando a comunicação não como um substantivo, mas como um verbo, tal como o conceito de organizing, cunhado por Weick, compreendendo-se a comunicação como o meio pelo qual os indivíduos coordenam ações, desenvolvem relacionamentos e mantém as organizações (PUTNAM e NICOTERA; 2009).

É nessa concepção que se destacam os trabalhos da "Escola de Montreal”. Convergente com o conceito de criação e recriação de sentido em um processo organizante realizado pelos membros da organização, este trabalho apresenta a abordagem da "Escola de Montreal' como um desdobramento da corrente de pensamento concebida por Weick, conforme se discorre a seguir.

\subsection{5}

\section{Organização como comunicação}

A “Escola de Montreal” desenvolveu-se inicialmente a partir dos trabalhos pioneiros de James Taylor, no departamento de comunicação da Universidade de Montreal, contudo, esta corrente de pensamento está atualmente amplamente difundida em diversos países e continentes. A partir do desafio de explorar a equivalência entre comunicação e organização, a “Escola de Montreal’ oferece uma perspectiva única da comunicação organizacional, porque propõe uma teoria comunicacional da constituição das organizações, sua abordagem diferencia-se 
pela construção de uma teoria das organizações baseada na comunicação. Suas investigações se voltam para a emergência das organizações pela comunicação. O pensamento da "Escola de Montreal" incorpora a análise interpretativa dos fenômenos sociais como processos simbólicos. Nessa ótica, as organizações são construções plurais instituídas nas práticas cotidianas de seus membros, compreendendo-se as organizações como sistemas de indivíduos em interação ativamente envolvidos em processos de criação e recriação de uma organização social através da geração de sentido (CASALI, 2009; WEICK, 2005).

Segundo Taylor e Casali (2010), a "Escola de Montreal” compreende as organizações através da comunicação, postulando que a organização emerge da comunicação por meio da dinâmica texto-conversação, isto é, os textos e as conversações ajudam a compreender melhor o fenômeno organizacional. A “Escola de Montreal” entende a comunicação como um meio para realizar ações. Os acadêmicos desta corrente de pensamento argumentam que a forma mais apropriada para expressar o significado do termo “comunicação organizacional” é organização na comunicação, e não o inverso, comunicação na organização, perspectiva que resulta na reificação da organização. Nesta nova perspectiva, compreende-se que uma organização é uma configuração de pessoas, tecnologias e práticas, integradas e mantidas pela comunicação entre os indivíduos.

Assim, a organização é construída nas conversas cotidianas dos indivíduos à medida que estes realizam suas atividades diárias e o agente responsável por efetivar as conexões desta formação é o texto e, portanto, a ação de textualizar. Normalmente, não percebemos as nossas conversas cotidianas serem mediadas pelos textos, contudo, os textos podem ser traduzidos para "realizar uma tarefa", não apenas em um contexto, mas em múltiplos contextos cuja única ligação uns com os outros é a de se referir e de recorrer aos mesmos textos. O texto é a ponte que passa por cima do abismo das conversações, isto é, entre as situações localizadas de interação. Um texto é gerado na comunicação e então, subsequentemente, instrui as conversações das diversas comunidades da organização (TAYLOR e CASALI, 2010, p.75).

A dinâmica texto-conversação representa um processo contínuo e circular em que conversações se transformam em texto e textos são traduzidos em conversações (TAYLOR et al., 1996). As organizações emergem de tal dinâmica e são resultado dessas traduções. Nesse processo, a comunicação é 
simultaneamente o contexto de emergência e o local de manifestação das organizações. A comunicação organizacional se constitui de um contínuo de textos e conversações, conforme representado pela figura 6 abaixo. Nesse fluxo, se produzem artefatos materiais e se reproduzem as estruturas sociais que constroem o ambiente. Assim, as organizações integram universos objetivos e subjetivos (CASALI, 2009).

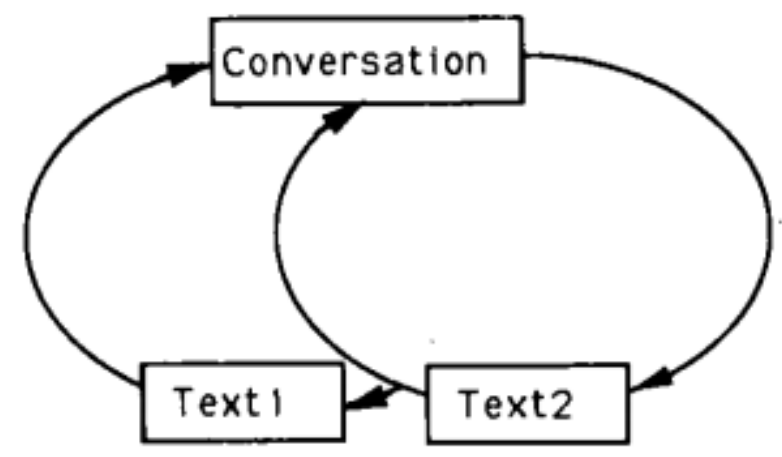

Figura 6: A Dinâmica Texto-Conversação. Fonte: TAYLOR (1996, p. 21).

Segundo Taylor (2014), nesta dinâmica, o texto representa uma manifestação do sensemaking humano (WEICK, 1995). A elaboração do texto é como os membros da organização reflexivamente (GIDDENS, 2003) e retrospectivamente (WEICK, 1995) monitoram, racionalizam e engendram a ação da organização. Por um lado, a conversação é um instrumento de ação organizacional, por outro, o texto é um recurso que entra em sua construção. Vinculada com os propósitos da organização, a conversação está ligada à atividade orientada ao objeto materialmente constituído. Em contraste, a comunicação por meio do texto constrói a organização como um objeto de reflexão e interpretação (TAYLOR et. al., 1996).

Segundo Taylor et al. (2004), a conversação é onde ocorre a organização. Sua finalidade é a coorientação dos membros da organização em relação uns aos outros através de algum objeto comum de preocupação. O efeito prático da conversação é estabelecer uma base de ação e manter a coordenação dos membros da organização em resposta a um ambiente material e social misto. Com efeito, as palavras são traduzidas em ação. Sensemaking, em contraste, invoca a linguagem 
sobre como os membros evocam o conhecimento de eventos anteriores através de lembranças e entendimentos de uma resposta adequada, dada a situação (WEICK, 1995). Eles usam a linguagem para nomear eventos e influenciar uns aos outros quanto a como eles agem; mas eles também a usam para se distanciarem do evento para compreendê-lo. Em outras palavras, eles constroem textos, e esses textos, por sua vez, tornam-se um ambiente para futuras conversações.

Este processo de organizing é contínuo, recorrendo-se regularmente à linguagem para conciliar os ambientes objetivos e subjetivos. Nesta perspectiva, o texto e a agência estão entrelaçados no papel da comunicação na ação humana. Assim, o processo de organização - a "conversação" organizacional - é uma combinação de influências, na medida em que a agência se baseia nos recursos da linguagem para realizar coorientação, enquanto os textos produzidos refletem seu envolvimento em um ambiente misto, ou "híbrido", material e social (LATOUR, 1994).

A “Escola de Montreal” propõe uma abordagem unificada na qual os objetos e ferramentas materiais, bem como as pessoas, desempenham um papel construtivo na constituição da agência. Nessa proposta a comunicação desempenha um papel fundamental tanto na gênese como na realização de uma atividade, assim como em dar sentido a ela. A organização, nesta proposição, é realizada através da coorientação à medida que os membros da organização se orientam simultaneamente para um objeto compartilhado de interesse e uns para com os outros. Para formar uma unidade de "organização", as pessoas precisam alinhar suas formas de lidar com o mundo objetivo, ao mesmo tempo que se situam dentro de um mundo social (TAYLOR et al., 2004).

Assim, a coorientação na proposta da "Escola de Montreal é a unidade mínima de comunicação e organização, representada pela relação A-B-X, conforme ilustrado pela figura 7. Esta relação é a unidade básica de análise da comunicação organizacional. A coorientação representa uma relação de troca em que no mínimo dois agentes (A e B), os quais podem ser tanto indivíduos, quanto organizações que utilizam a linguagem para interação, têm sua atenção focada em um mesmo objeto (X), o qual representa elementos do ambiente material e social passíveis de interpretação e que incorporam significados (CASALI, 2009). 

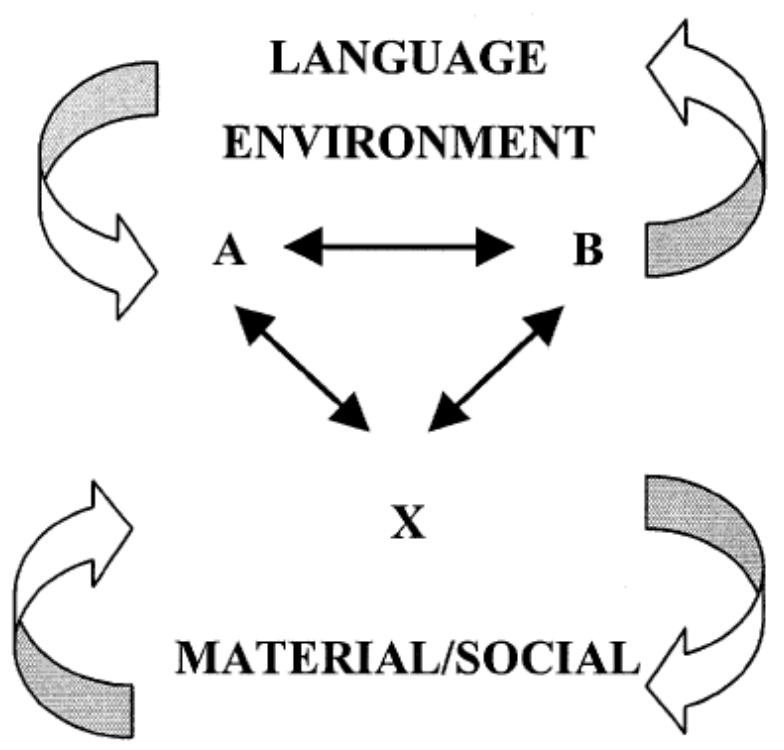

ENVIRONMENT

Figura 7: Coorientação através da Conversação como a Unidade Relacional Essencial de Organização.

Fonte: TAYLOR et al. (2004).

Assim, alinhando as respectivas orientações sujeito-objeto (as ligações AX, B-X da Figura 7) é onde a organização começa. Estabelecer coorientação e responder a um mundo misto material e social é a essência da prática organizacional. Objetos surgem dentro dessa prática (TAYLOR et al., 2004).

O status ontológico de uma organização é controverso. O que sabemos de uma organização chega até nós através da conversa organizacional e textos que captam nossa atenção. As conversas são as mais imediatas e convincentes das muitas mídias discursivas disponíveis para desenvolver o conhecimento da organização. É aí que nossa experiência de organização é simultaneamente vivida, interpretada e reinterpretada. É nas conversas dos membros da organização que as energias das pessoas são mobilizadas para lidar com o mundo e interpretar o que está ocorrendo enquanto falam (BODEN, 1994, apud TAYLOR et al., 2004).

Deste modo, a "Escola de Montreal” afirma que o diálogo, enquadrado dentro de um ambiente material / social e de linguagem, é o local onde ocorre a organização. Os diálogos geram tanto a agência, quanto o texto. A agência reflete os meios e os fins dos atores sociais e as tecnologias materiais que eles empregam. Os textos refletem as práticas de sensemaking e os hábitos de interpretação de uma comunidade em relação à prática que foi formada para lidar com algum ambiente material / social. O processo de organização é recursivo, na medida em 
que as ações e interpretações da comunidade geram as circunstâncias que os membros da comunidade precisam abordar. A linguagem reside na comunicação como uma habilitação e uma restrição, bem como fora dela como um de seus ambientes. Nós moldamos nossos ambientes como eles nos moldam. Como os moldamos e somos moldados por eles é uma questão de prática. Vemos assim a organização e a comunicação como co-constitutivas, em outras palavras, a organização emerge através da comunicação (TAYLOR et al. 2004).

Assim, a "teoria da coorientação” congrega a dimensão pela qual a comunicação deixa de ser instrumental para se tornar elemento constitutivo das organizações na construção e no compartilhamento de significados. Por meio da imbricação de diversas unidades relacionais A-B-X observa-se a emergência das organizações pela comunicação (CASALI, 2009, p. 119).

Aplicando esta teoria justamente à projetos de implementação de $E R P$, Taylor (2008, p. 82) conclui que:

"Muitas das dificuldades que os membros de equipe deste tipo de projeto enfrentam, está no fato de que muitos dos participantes do projeto ainda tendem a ignorar o simples fato de que uma organização, em sua própria essência, não é apenas um conjunto de práticas, para ser estruturalmente redesenhada. Ela é um texto - e é um texto que possui autoridade para aqueles que nela trabalham. Muitos ainda pensam em comunicação apenas como o que se passa em uma organização. O que não conseguem entender é que a organização é em si uma construção comunicativa. Quando um projeto de implementação de um sistema ERP é realizado, não são apenas as práticas que devem mudar, o texto também deve ser reescrito. Mas o texto não é meramente um relato de práticas. É também um tecido de identidades: vivido, não meramente transcrito ao texto. Transformar as identidades das pessoas é uma questão muito mais delicada do que simplesmente alterar algumas práticas. O sistema de autoridade que é legitimado pelo seu texto é a espinha dorsal da organização”. 


\section{3}

\section{Metodologia}

A curiosidade em relação ao desconhecido é o motor da prática científica que envolve um conjunto de tarefas a serem realizadas simultaneamente ou em diferentes etapas. Entre elas estão a demarcação de um quadro teóricometodológico. Assim sendo, a escolha das estratégias de pesquisa não é uma decisão arbitrária, pois se fundamenta na aceitação de certos pressupostos epistêmico-metodológicos - uma construção conceitual que delimita o recorte a ser efetuado na realidade com objetivos analíticos (COLBARI, 2014).

Neste trabalho realizou-se uma pesquisa dentro da qual optou-se por uma investigação de cunho qualitativo. Este tipo de abordagem, segundo Silva e Fossá (2013) tem se destacado por sua utilização em temas emergentes no campo da Administração, os quais são realizados por meio de estudos exploratórios.

Dentro da abordagem qualitativa, a técnica selecionada para a realização da análise dos dados qualitativos foi a análise de conteúdo, técnica que tem sido amplamente utilizada na análise dos dados qualitativos. A análise de conteúdo consiste em uma técnica de análise das comunicações, por meio da qual propõemse analisar o que foi dito nas entrevistas ou observado pelo pesquisador (SILVA e FOSSÁ, 2013).

A análise de conteúdo é uma técnica de pesquisa para fazer inferências replicáveis e válidas de textos para os contextos de seu uso. Como técnica de pesquisa, a análise de conteúdo fornece novos insights, aumenta a compreensão de um pesquisador sobre fenômenos particulares ou informa ações práticas. A análise de conteúdo é uma ferramenta científica (KRIPPENDORFF, 2004).

A análise de conteúdo trabalha tradicionalmente com materiais textuais escritos, textos que são construídos no processo de pesquisa, tal como as transcrições de entrevistas. As entrevistas, doravante, tem sido o principal método no qual tem se baseado a grande maioria das pesquisas sociais. A entrevista, seja ela estruturada ou não, é um método conveniente e estabelecido de pesquisa social (BAUER, 2008). 
O mundo social não constitui uma realidade sui generis divorciada dos seres humanos, mas é produto da própria existência humana. Isso não implica negar os fatos, ou a existência da realidade objetiva, mas sim admiti-la como dependente dos sujeitos humanos e da estrutura de significados e resultante da forma como o mundo é vivenciado e explicado pelos sujeitos. As diversas formas de emprego da linguagem, como conversas, falas, narrativas e textos, são práticas interativas de construção do mundo social. Por meio delas, as pessoas constroem sentidos e significados em suas ações e relações na vida cotidiana e participam da construção social do mundo (COLBARI, 2014).

As pessoas usam a linguagem para representar o mundo como conhecimento e autoconhecimento. Para reconstruir esse conhecimento, a análise de conteúdo pode orientar-se na direção de construção de redes de unidades de análise para representar o conhecimento por meio das relações entre texto e contexto (BAUER, 2008).

Deste modo a análise de conteúdo nos possibilita a realização da análise sem necessariamente optar-se pela separação do estudo em objetivo ou subjetivo, antes, possibilita uma aproximação dos dois, uma vez que o método admite que o discurso informe sobre ambas as realidades e provoca o questionamento sobre suas relações (DELLAGNELO e SILVA, 2005).

Deste modo, neste trabalho, optou-se por uma pesquisa com estudo de caso, realizada através de entrevistas, pois, este estudo tem como proposta a análise em profundidade da percepção dos indivíduos participantes de um projeto organizacional, buscando-se uma melhor compreensão do papel da comunicação no gerenciamento de projetos.

O caso selecionado para este estudo é detalhado no próximo capítulo, no entanto, em síntese, o caso trata-se de um projeto organizacional de implementação dos módulos de Recursos Humanos de um ERP SAP, realizado na empresa ABC. Para as entrevistas foram escolhidos os membros com participação integral no projeto, conforme é detalhado no tópico seguinte. 


\section{1}

\section{Seleção dos sujeitos}

A seleção teve foco nos indivíduos com participação integral no projeto selecionado para o estudo de caso. Por integral entende-se que houve dedicação exclusiva destes indivíduos em determinado período do projeto ou ao longo de todo o projeto.

A seleção de entrevistados escolhidos para este estudo compreendeu os seguintes critérios:

- Ser um colaborador da empresa ABC: Funcionários permanentes pertencentes ao quadro de pessoal da empresa ABC. Este é um critério relevante para este trabalho, dado que neste estudo aborda-se a comunicação como constitutiva das organizações;

- Participação no projeto Novos Horizontes: Funcionários que participaram exclusivamente do projeto selecionado para o estudo de caso;

- Recurso exclusivo do projeto: Como é comum em projetos desta magnitude, este projeto contou com a colaboração de colaboradores com participação integral ou parcial. Para este trabalho, optou-se pela escolha apenas de pessoas que com participação integral no projeto selecionado;

- Ser membro de um grupo representativo do projeto: O projeto contou com a colaboração de diferentes áreas da organização. Contudo, por tratar-se de uma implementação de uma solução para Recursos Humanos, foram escolhidas pessoas que representassem um dos grupos mapeados como tendo maior expressividade dentro do projeto selecionado, conforme destacados na figura 8: 


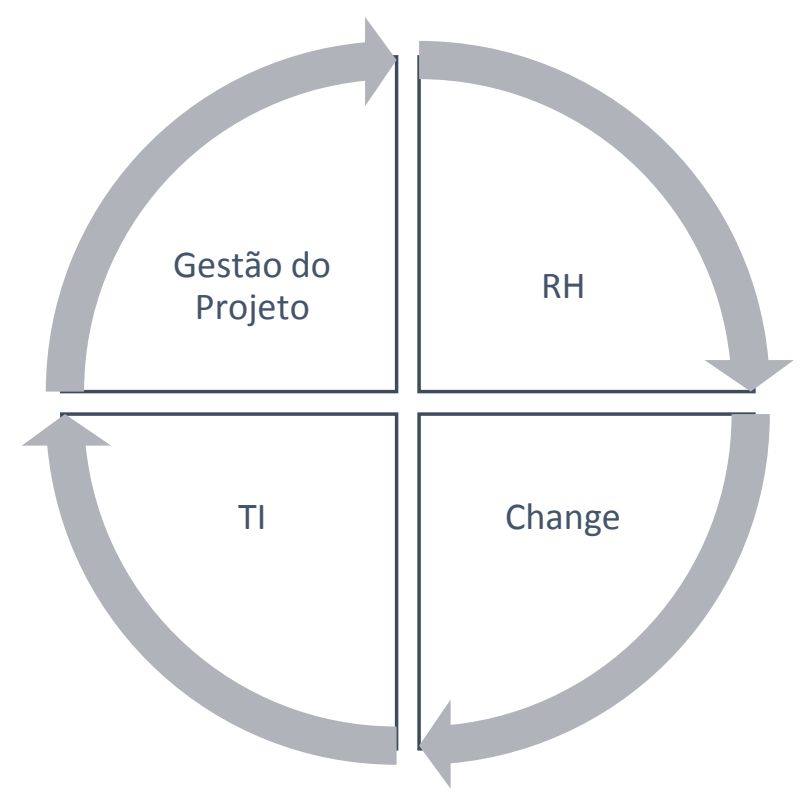

Figura 8: Áreas representativas do projeto.

Fonte: Elaborado pelo próprio autor.

A seleção é composta por 8 (oito) entrevistados, definida pelo critério de intencionalidade, além dos apresentados anteriormente. Os dados demográficos dos entrevistados e da distribuição do grupo de representatividade são demonstrados a seguir:

Tabela 1: Dados demográficos pessoais.

Tabela 1 - Dados demográficos pessoais

Tempo de Empresa

Feminino

Masculino

\section{Etnia}

Branco

Pardo

\section{Educação}

Ensino Superior

\section{Geração}

Baby Boomers

Geração X

(50 - 99 Anos)

Geração Y

\section{Percentual Quantidade}

$62,5 \%$

$37,5 \%$

5

3

$62,5 \%$

$37,5 \%$

5

3

$100,0 \%$

8

$25,0 \%$

5

$62,5 \%$

$12,5 \%$ 
Tabela 2: Dados demográficos organizacionais.

\section{Tabela 2 - Dados demográficos organizacionais}

\author{
Tempo de Empresa \\ 01 - 03 Anos \\ 04 - 06 Anos \\ 07 - 09 Anos
}

\section{Área da Empresa}

Desenvolvimento Humano e Organizacional

Tecnologia da Informação

\section{Grupo Representativo do Projeto}

$\mathrm{RH}$

$\mathrm{TI}$

Change

Gestão do Projeto

$\begin{array}{cc}\text { Percentual } & \text { Quantidade } \\ 12,5 \% & 1 \\ 62,5 \% & 5 \\ 25,0 \% & 2\end{array}$

$62,5 \%$

5

$37,5 \%$

3

$\begin{array}{ll}50,0 \% & 4 \\ 25,0 \% & 2 \\ 12,5 \% & 1 \\ 12,5 \% & 1\end{array}$

Tabela 3: Cargo versus função no Projeto.

\section{Tabela 3 - Cargo x Função no Projeto}

\begin{tabular}{lll}
\hline \multicolumn{1}{c}{ Cargo } & Área & \multicolumn{1}{c}{ Função no Projeto } \\
\hline Analista DHO Júnior & DHO & Key-user \\
\hline Analista DHO Pleno & DHO & Key-user \\
\hline Analista DHO Sênior & DHO & Key-user \\
\hline Analista DHO Sênior & DHO & Change \\
\hline Gerente de Operações DHO & DHO & Patrocinadora do Projeto \\
\hline Analista de Sistema SAP Sênior & $\mathrm{TI}$ & Analista de Sistema SAP \\
\hline Analista de Sistemas Sênior & $\mathrm{TI}$ & Analista de Integrações \\
\hline Gerente de TI & $\mathrm{TI}$ & Gerente do Projeto \\
\hline
\end{tabular}

A tabela 1 representa os dados demográficos dos participantes. Observa-se que o participante típico é, em sua maioria, do sexo feminino, de cor branca, da geração “ $X$ ”, com ensino superior completo.

A tabela 2 é uma representação da demografia organizacional dos mesmos participantes. Os dados, neste caso, apresentam um representante típico como uma pessoa com aproximadamente 5 anos de empresa, da área de Recursos Humanos 62,5\%, ou Tecnologia da Informação - 37,5\% e pertencente à um dos grupos representativos do projeto. 
A tabela 3 apresenta uma relação entre cargo e função desempenhada no projeto, além da área de alocação do participante na organização.

\section{2}

\section{Procedimentos e Instrumentos de Coleta de Dados}

A pesquisa bibliográfica foi feita em textos específicos sobre os temas de estudo, buscando-se uma revisão da literatura e aprofundamento sobre os temas gerenciamento de projetos e comunicação organizacional.

Para a coleta das narrativas foram realizadas entrevistas semiestruturadas com os participantes do projeto selecionado.

Para obter a riqueza necessária, a entrevista conteve uma estrutura de duas categorias de questões: questões principais e perguntas de apoio.

As entrevistas foram realizadas nas dependências da empresa ABC, durante o período de execução do projeto, em sua maioria após o expediente de trabalho, dado que devido à intensidade do projeto em andamento, apresentaramse dificuldades de se conciliar a disponibilidade de agenda dos entrevistados com a disponibilidade de salas de reunião para a realização das entrevistas.

As entrevistas com os membros do projeto foram direcionadas pelas sete questões principais, todas no formato de questões em aberto, além de 5 perguntas de apoio, conforme descrito a seguir:

Questões Principais:

1. Você poderia contar um pouco sobre sua formação, um breve histórico sobre seu tempo de atuação na empresa, e como você se inseriu no contexto do projeto Novos Horizontes?

2. O que você pensa sobre a implementação do projeto Novos Horizontes na organização?

3. Quais os pontos você elencaria como fatores positivos nesta implementação?

4. Quais os pontos você elencaria como fatores negativos nesta implementação?

5. Como você vê o papel da empresa nesta implementação?

6. Como você vê o seu papel no projeto?

7. Como você vê a comunicação na implementação do projeto? 
Perguntas de Apoio:

1. Quem estava envolvido nesta situação?

2. Quais os fatores envolvidos?

3. Pode exemplificar com alguma situação?

4. Você enxerga isso como uma barreira à comunicação?

5. Você enxerga isso como favorável à comunicação?

As entrevistas duraram, em média, 40 minutos, permitindo que o pesquisador obtivesse uma perspectiva profunda sobre os pensamentos, raciocínio, motivações e sentimentos do participante, em relação a:

1. Visão do papel da comunicação no projeto;

2. Motivações e forma de pensar em relação ao projeto;

3. Sentimentos em relação aos outros membros do projeto;

4. Forma de pensar em relação ao gerenciamento de projetos na organização.

As entrevistas foram realizadas no período de outubro de 2016 a janeiro de 2017. Todos os entrevistados demonstraram forte abertura para expressarem suas opiniões, com boa receptividade e interesse em participar da pesquisa, que tem como estudo de caso o projeto por eles vivenciado.

\section{3}

\section{Tratamento dos dados}

Cada entrevista realizada foi gravada utilizando-se o recurso de gravação de um aparelho celular pessoal. Os áudios foram transferidos para computador, ouvidos pelo próprio entrevistador e transcritos digitalmente em documentos para leitura. O escrutínio dos dados foi realizado utilizando-se a técnica de análise de conteúdo, neste capítulo apresentada, analisando-se o que foi dito nas entrevistas ou percebido pelo pesquisador durante as entrevistas.

A análise foi suportada pelo referencial teórico apresentado no segundo capítulo deste trabalho, resultado da pesquisa bibliográfica realizada, buscando-se identificar como a comunicação é percebida pelos indivíduos entrevistados e 
como isto afetou a criação de sentido no processo de mudança provocado pelo projeto.

\section{4}

\section{Limitações do método}

Devido ao fato de não ser possível realizar a entrevista com todos as pessoas envolvidas no projeto, além das demais partes interessadas, existe a possibilidade de o grupo selecionado enviesar a pesquisa.

Além disso, as opiniões expressadas pelos indivíduos entrevistados podem não representar integralmente suas visões de realidade do contexto organizacional, o qual buscou-se capturar por meio das entrevistas realizadas.

Devido ainda ao período de realização das entrevistas, fase do projeto de alta intensidade emocional, a realidade capturada contém as restrições das influências características deste momento. 


\section{Caso}

\section{1}

\section{O Grupo ABC}

O projeto adotado como estudo de caso para este trabalho realizou-se em uma renomada Companhia prestadora de serviços aos setores de comércio marítimo nacional e internacional no Brasil. Para efeitos de confidencialidade, a Companhia será identificada neste trabalho como Grupo ABC. Como fonte foram utilizadas as obras disponibilizadas pelo próprio Centro de Memória da Companhia, localizado na matriz do Grupo, no Rio de Janeiro. O Centro de Memória do Grupo ABC foi inaugurado em 2005, destinado não só ao resgate do seu passado, como também da sua relação com a história do Brasil. O Centro de Memória dispõe de uma rica documentação, que se estende do século XIX até os dias atuais.

As atividades do Grupo ABC tiveram início no Brasil em 1837, em Salvador, Bahia, como uma empresa dedicada às atividades de navegação e ao comércio de carvão. Até a última década do século XIX, a ABC passou por diversas etapas de evolução.

$\mathrm{Na}$ área de exportação, foi responsável por 28\% do fumo e derivados enviados para Europa e América do Norte e por 40\% do açúcar branco e mascavo, além de comercializar coquilhos, ouro em pó, barras de prata e madeira, tornandose uma importante prestadora de serviços de navegação, estiva e Rebocagem.

Em 1870, quando estreou oficialmente no Rio de Janeiro, a empresa passou a responder por $30 \%$ do volume global das mercadorias que entraram no Brasil pela Bahia. Além dos negócios com carvão, a ABC atuou nos negócios mais rentáveis da época, como a importação de manufaturas de algodão, lã, linho e seda.

Em 1889, com a instituição da República no Brasil, iniciou-se uma fase de ajustes nos negócios, impulsionada pela mudança do cenário econômico no país. A empresa $\mathrm{ABC}$, que neste período já havia se tornado a maior empresa de 
navegação brasileira, teve seu controle comprado por uma companhia estrangeira, do país de Gales.

Até os anos 1950 a ABC se expandiu e se consolidou também como a maior trade company do Brasil, com uma extensa lista de representações, além de ampliar suas atividades para segmentos diferenciados, como a produção de sal.

No decorrer do tempo, o carvão perdeu gradativamente sua importância como matriz energética em todo o mundo, sendo substituído pelo petróleo, o que forçou a companhia a não somente diversificar, mas a reinventar-se.

Em 1954, um banqueiro inglês, percebendo o potencial da empresa, convenceu um grupo de investidores a adquiri-la. Após fechar negócio, ele veio pessoalmente ao Brasil para gerir e redefinir os negócios, concentrando-se em navegação e rebocadores.

Durante toda a década seguinte, promoveram-se mudanças profundas. Entre os anos de 1960 e 1970, no auge do milagre econômico brasileiro, a ABC voltou a expandir-se, adquirindo ativos junto aos principais portos brasileiros. Também se tornou mais presente no agenciamento e na indústria naval.

Esse crescimento foi sustentado pela decisão estratégica de renacionalizar a empresa, transferindo sua sede de Londres para o Rio de Janeiro. Em 1987, o Grupo ABC já compreendia sete companhias operacionais ligadas às áreas de navegação, tecnologia e veículos, além de vários outros pequenos negócios.

Em 1988, o Grupo inicia um processo de mudanças culturais, inicialmente com foco na área de navegação, o que transformou a ABC na primeira empresa especializada em rebocadores da América Latina.

Nos anos 1990, ao se reposicionar estrategicamente, o Grupo ABC partiu para o desenvolvimento de novos negócios e definiu sua participação em atividades com grande potencial de crescimento. Na velocidade típica dessa nova era, os investimentos foram direcionados a oportunidades relacionadas aos negócios tradicionais, fazendo surgir os segmentos de logística, de terminais e de offshore. Negócios integrados, porém, cada um com dinâmica própria de desenvolvimento.

Em 2004 ocorreu a unificação dos negócios: Logística, Terminais, Agência Marítima, Estaleiros e Rebocadores. Coroando esse ciclo de mudanças, em 2007 o Grupo ABC abriu seu capital, buscando sua perpetuidade perante o cenário globalizado. 
Em 2016 o grupo ABC completa 180 anos de existência. Sua filosofia visionária de somar a uma enorme tradição histórica um compromisso de evolução constante está presente na estratégia de crescimento e forma de atuação de cada empresa do Grupo, proporcionando um diferencial de abrangência e qualidade de serviços diferenciados no mercado nacional. Investindo continuamente em sua estrutura de informação, operação e equipamentos, o Grupo ABC incorpora a cada dia mais agilidade, mais segurança e tecnologia de ponta para estar à frente do seu tempo, revolucionando no Brasil o conceito de eficiência em Terminais Portuários, Rebocagem, Logística, Agenciamento Marítimo, Offshore e Estaleiros.

O grupo está presente em mais de quinze estados brasileiros, atuando no mercado interno e no comércio internacional, com representações na Europa, nos Estados Unidos, além de contar com escritório próprio na China. Com faturamento anual superior à meio bilhão de dólares americanos, segundo relatório anual de 2015, o Grupo ABC conta com mais de cinco mil funcionários em seu quadro funcional, além de um ativo total de aproximadamente um bilhão de dólares americanos.

\section{2}

\section{A área de Desenvolvimento Organizacional}

A área de Recursos Humanos da companhia é representada pela diretoria de Desenvolvimento Organizacional (DO), a qual possui três frentes voltadas ao atendimento das unidades de negócio. São elas:

- Desenvolvimento Humano e Organizacional (DHO);

- Comunicação e Sustentabilidade;

- Segurança, Meio Ambiente e Saúde.

O Desenvolvimento Humano e Organizacional está dividido em três gerências:

- Operações DHO;

- DHO Desenvolvimento;

- Recompensa e Planejamento DHO. 
Na imagem a seguir é possível perceber um breve resumo das atribuições da área de DHO:

\section{OPERAÇÕES DHO}

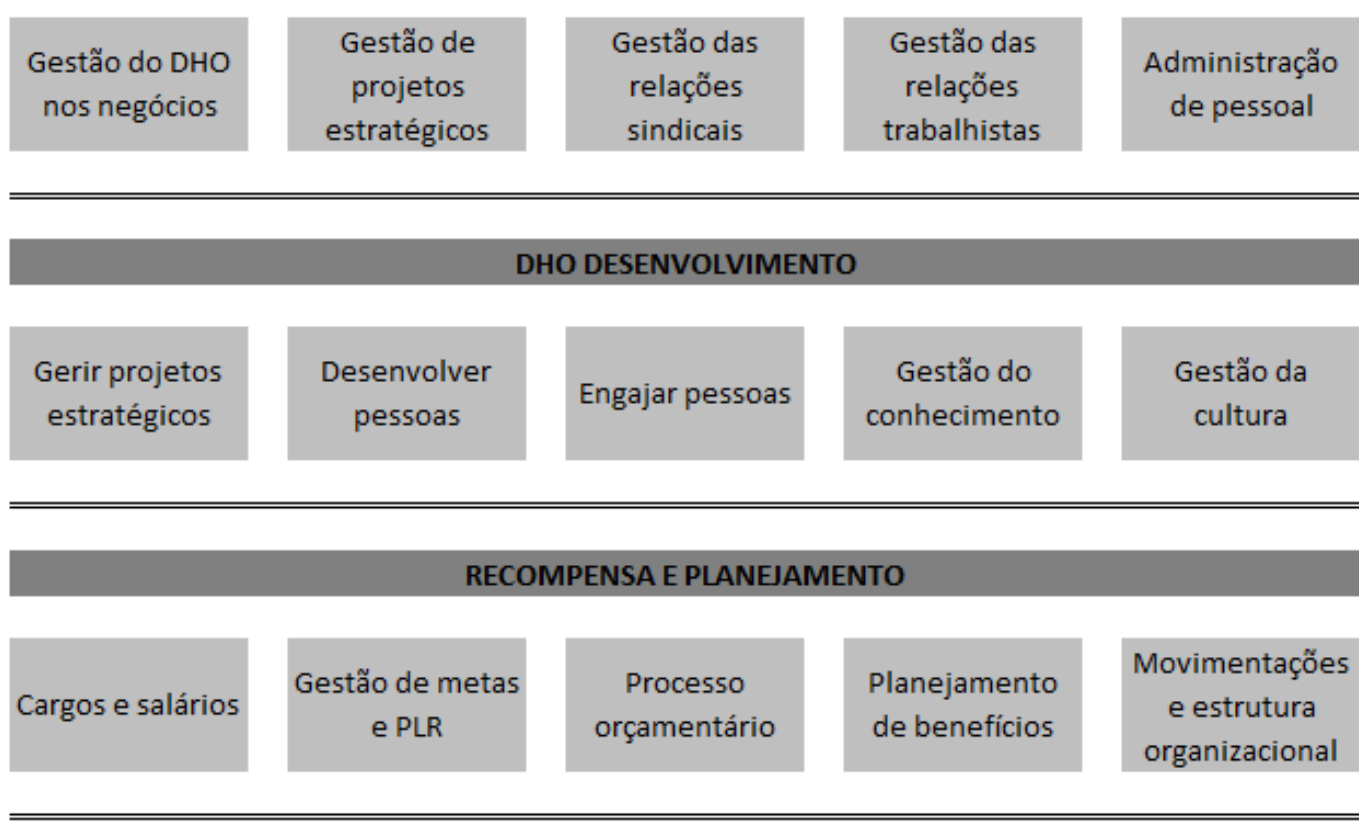

Figura 9: Frentes de atuação da área de $D H O$ na empresa $A B C$. Fonte: Centro de Memória da Empresa ABC.

Frente ao alinhamento estratégico do Grupo ABC, identificou-se a necessidade de a empresa possuir sistemas DO mais integrados e alinhados às metas da empresa. Assim, a área de DO, em conjunto com a área de TI, elaborou um programa de renovação tecnológica, cujo roadmap se estende de 2016 a 2019 e que se propõe a:

- Buscar eficiência, eficácia e inovação nos processos que geram diferenciação e ganhos reais;

- Ter os processos de suporte alinhados às melhores práticas, às necessidades dos negócios e compatíveis com os resultados do Grupo;

- Assegurar tecnologia e infraestrutura compatíveis com as necessidades dos negócios;

- Aumentar o engajamento dos colaboradores. 
A estruturação deste Roadmap transformou-se no Projeto Novos Horizontes, cuja primeira fase compreendeu um projeto de implementação do ERP SAP HCM.

\section{3 \\ Projeto Novos Horizontes}

No ano de 2012, a empresa ABC colocou no ar o sistema ERP SAP. Na ocasião implantou-se toda a parte de BackOffice, para todas as razões sociais do Grupo, além de uma solução de logística para o estaleiro localizado no Guarujá, litoral de São Paulo, onde toda a cadeia produtiva passou a ser atendida pelo ERP SAP. A implantação levou 15 meses e englobou 15 módulos da solução para as áreas de finanças, controladoria, controle e planejamento de produção, vendas, gestão de qualidade, manutenção de planta, administração de compras e inventário, gestão de projetos, entre outros. No entanto, na ocasião, tomou-se a decisão estratégica de não incluir a implementação de soluções para Recursos Humanos, levando-se em consideração que a complexidade e as peculiaridades de uma implementação de sistemas deste porte para a área de Desenvolvimento Organizacional da companhia exigiriam um projeto próprio. Este projeto próprio iniciouse em 2016, batizado com o nome Projeto Novos Horizontes, dividindo-se em diferentes fases, estendendo-se até o ano 2019. Nesta dissertação, tomamos para o estudo de caso para a pesquisa pretendida o Projeto Novos Horizontes - Fase I, cujo escopo abrangeu a implementação de soluções para a área de DHO.

O projeto compreendeu a implementação de uma solução híbrida da SAP. A SAP é uma empresa de origem alemã, fundada em 1972, atualmente líder global em aplicações empresariais em termos de receita de software e serviços relacionados com software. Seu principal produto é o ERP SAP, no entanto, sendo uma gigante tecnológica, tem fortalecido seu portfólio de produtos com diferentes tendências em tecnologia, como a computação em nuvem, ou cloud computing.

A solução híbrida implementada no Projeto Novos Horizontes - Fase I incluiu o ERP SAP HCM, em conjunto com o sistema cloud SuccessFactors Employee Central, além da adequação de diversos sistemas periféricos à nova solução.

$E R P$, conforme já mencionado anteriormente no primeiro capítulo deste trabalho, corresponde à sigla para Enterprise Resource Planning. Em português, é 
comumente traduzido para Sistemas de Gestão Empresarial e representado pela sigla SIG.

HCM corresponde à sigla para Human Capital Management. O HCM corresponde ao módulo de Recursos Humanos do ERP SAP. O ERP SAP HCM divide-se em diferentes aplicações, tendo-se implementado cinco delas neste projeto, a saber:

- Personnel Administration (PA) - Administração de Pessoal

- Benefits (BN) - Benefícios

- Payroll (PY) - Folha de Pagamento

- Compensation Management (CM) - Cargos e Salários

- Organizational Management (OM) - Estrutura Organizacional

O SuccessFactors Employee Central, implementado em conjunto com o ERP SAP HCM, é um sistema de Recursos Humanos baseado em computação na nuvem, acessado através da web, o qual combina recursos de Administração de Pessoal e Estrutura Organizacional com recursos de colaboração social. Na mesma plataforma disponibiliza-se um portal para os colaboradores no qual se fornecem informações concernentes à sua vida laboral, enquanto a equipe de Recursos Humanos realiza na nuvem o processo de gestão dos colaboradores.

O SuccessFactors Employee Central é integrado ao ERP SAP HCM, compondo-se uma solução híbrida, unificando a estabilidade e tradição de um sistema de recursos humanos há anos consolidado no mercado - o ERP SAP HCM, com a inovação da computação em nuvem - o SuccessFactors Employee Central.

O projeto teve duração de treze meses, compreendendo cinco fases, conforme previsto pela metodologia ASAP: Project Preparation, Blueprint, Realization, Final Preparation e Go Live e Support (GULLEDGE et al., 2005). A figura 10 apresenta a visão macro do cronograma do projeto. 


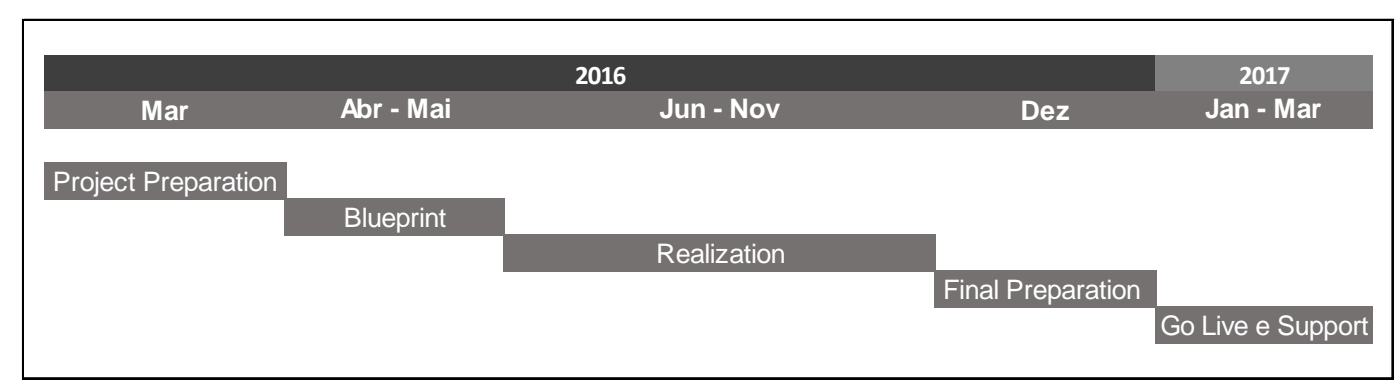

Figura 10: Visão macro do Cronograma do Projeto Novos Horizontes - Fase I. Fonte: Documentação do Projeto Novos Horizontes - Fase I.

O custo total do projeto foi orçado em aproximadamente quatro milhões de reais e contou com o esforço de diferentes áreas, vinte e quatro pessoas com alocação integral e mais de trinta pessoas com alocação parcial, distribuídas no organograma demonstrado na figura 11 - Organograma do Projeto.

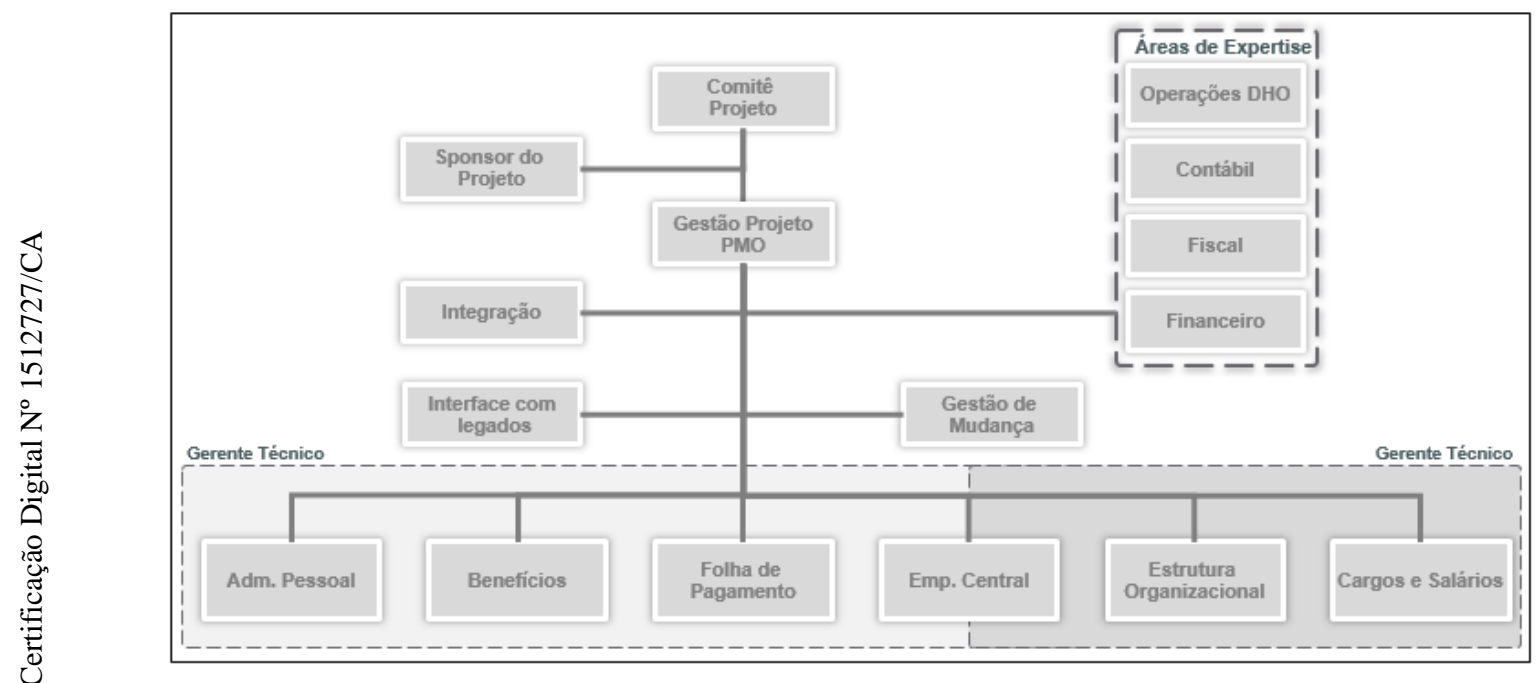

Figura 11: Organograma do Projeto.

Fonte: Documentação do Projeto Novos Horizontes - Fase I.

O projeto foi realizado fisicamente na matriz do Grupo ABC, em um prédio localizado no Rio de Janeiro. Os membros do projeto com dedicação integral foram alocados fisicamente no local do projeto. Outros membros do projeto com dedicação parcial atuaram tanto presencialmente, quanto remotamente. Inicialmente não houve um espaço comum para todos os participantes do projeto, de tal forma que os membros se reuniram em grupos distribuídos nas salas de reunião da empresa. Posteriormente, durante a fase de Realization do projeto, a equipe do projeto conseguiu a disponibilidade de uma sala que comportasse todos os membros com dedicação integral. Seu uso estendeu-se até o Go Live do projeto. Após o Go Live, durante a fase de Support, 
os membros do projeto voltaram gradualmente a serem acomodados em suas respectivas áreas.

A comunicação do projeto foi planejada por um esforço colaborativo da gestão do projeto, da equipe de gestão da mudança do projeto a qual contou com a participação de membros internos da empresa e de consultoria especializada em gestão da mudança, e da área de comunicação organizacional do Grupo ABC.

Utilizaram-se diferentes ferramentas tanto para a comunicação, quanto para o gerenciamento do projeto, incluindo o Microsoft Project, Microsoft Word, Microsoft Excel, Microsoft Power Point, Smartsheet, Google Documentos, Google Planilhas, Google Apresentações, Google Gmail e Adobe PDF. Todos os documentos foram hospedados na nuvem utilizando o Google Drive. O Grupo ABC adotou oficialmente as ferramentas Google e encontra-se atualmente em período de transição, descontinuando o uso das ferramentas da Microsoft. Por isso, ferramentas de ambos os fornecedores se encontram presentes na lista de ferramentas utilizadas no projeto.

O planejamento das comunicações do projeto planejou reuniões periódicas para todo o período de existência do projeto, conforme demonstra-se na figura 12 - Governança do Projeto. No entanto, diversas reuniões extraordinárias foram realizadas para as mais diferentes finalidades, tais como discussões de processos, alinhamentos de expectativas e entendimentos, discussão de problemas críticos e emergenciais, só para citar alguns exemplos. 


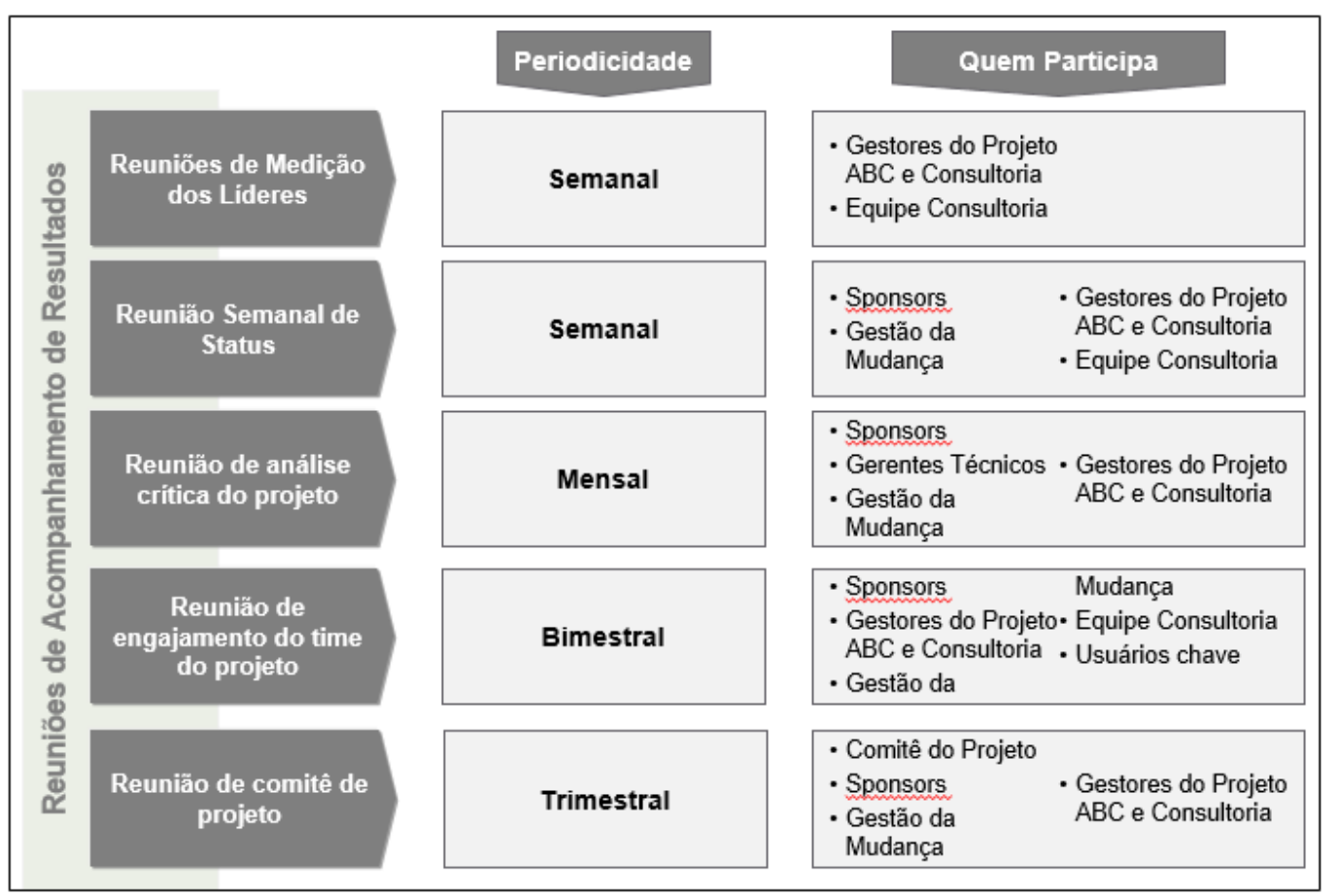

Figura 12: Governança do Projeto.

Fonte: Documentação do Projeto Novos Horizontes - Fase I.

Concluindo, o Go Live do projeto ocorreu dentro do período previsto, sendo considerado um projeto de sucesso em diferentes perspectivas. No entanto, muitos foram os percalços em sua realização, em especial no que tange à comunicação, havendo muitas oportunidades de melhorias e aprendizados. Deste modo, o capítulo seguinte apresenta a análise das entrevistas as quais foram realizadas com o objetivo de se capturar a compreensão da comunicação do projeto na perspectiva dos participantes do projeto, além de se buscar oportunidades de contribuição da literatura em gerenciamento de projetos e da comunicação como constitutiva das organizações. 


\section{Análise e interpretação dos resultados da pesquisa}

Neste capítulo é apresentado o resultado da análise das entrevistas realizadas com os participantes do projeto selecionado como caso de uso para este estudo. Para as análises foi aplicada a técnica de análise de conteúdo.

\section{1}

\section{Análise do conteúdo das entrevistas}

As perguntas norteadoras realizadas nas entrevistas tiveram por objetivo investigar a percepção do entrevistado quanto ao fenômeno da mudança provocado pelo projeto estudado, segundo a visão de mundo dos participantes do projeto. Nas respostas pode-se observar a construção de uma nova realidade social realizada por meio de um processo organizante, com significados subjetivos para cada indivíduo e ao mesmo tempo compartilhados sinergicamente pelo grupo. Entre erros e acertos no projeto, nota-se que há contribuições tanto objetivas, quanto subjetivas, que em conjunto oferecem ricas oportunidades de aprendizado e de avanço, mesmo que modesto, no campo de conhecimentos em comunicações em gerenciamento de projetos. Desta forma, apresenta-se a seguir a análise das entrevistas realizadas sob à ótica do aporte teórico em gerenciamento de projetos e em comunicação organizacional.

\subsection{1}

\section{Gerenciamento de projetos}

O grupo estudado, mesmo tratando-se de uma companhia relativamente conservadora, com seus 180 anos de existência, é uma organização com sede de inovação e que regularmente investe em mudanças que se concretizam por meio de seus muitos projetos. Nessa dicotômica inovação conservadora, observa-se o conservadorismo da organização em seu portfólio sem muitas novidades, contudo observa-se também uma constante busca pelo pioneirismo em ações da 
organização dentro de seu nicho de atuação no mercado, conforme relatado pelos indivíduos entrevistados:

“...a ABC sempre foi pioneira.”. (E4)

“A gente na verdade entrou num pioneirismo... nós somos pioneiros.”. (E8)

Em consonância com Kerzner (2002, p.17), o desafio para a empresa que não quer ser apenas mais uma no mercado, consiste em realizar atividades nunca realizadas antes e que também não se repetirão no futuro.

Deste modo, pode-se dizer que a organização estudada tem se movido rumo a novos horizontes, conforme sugerido pelo nome do projeto tomado para estudo de caso, através da realização contínua de projetos organizacionais que movem o grupo para novas realidades que visam manter a organização competitiva nos negócios em que atua. A constância dos projetos organizacionais é uma realidade percebida pelos entrevistados, conforme pode-se observar nas falas destacadas a seguir:

"Eu entrei na $A B C$ em 2012, para um outro projeto, o projeto Novos Mares, que foi o projeto de implementação de toda base SAP da ABC... foi um projeto muito intenso, com um número muito grande de pessoas envolvidas... [Depois] com a estabilização do SAP, já se visava fazer uma outra onda de projeto para implantação do SAP HCM... A empresa tem muitos projetos.”. (E1).

"Ainda mais que outros projetos irão surgir por conta deste atual, como reflexo em outras áreas. ”. (E2)

“...eu vejo esse projeto se desdobrando para outros anos, eu não o vejo como um projeto, mas como um programa... onde a fase que nós estamos é implementar um projeto que irá dar base para o futuro que a $A B C$ deseja construir. ”. (E3)

Observa-se também, sob a ótica dos entrevistados, que embora os projetos façam parte da realidade da organização, o grupo ABC carece, de alguma forma, da utilização de mais conhecimento formal em gerenciamento de projetos, conforme relatos descritos a seguir:

"Com o passar do tempo...a gente percebe o quanto faltam algumas informações de gerenciamento de projetos... quando eu fui fazer a certificação Prince2 eu fui pesquisar se no grupo existia alguém com formação em Prince2. Não tem. Depois eu fui procurar saber se existe 
alguém certificado, é.... como PMP. Existia uma pessoa que é PMP, e ela não está na matriz, está em uma das empresas do grupo... verifiquei que existem muitas pessoas procurando essa informação, fazendo curso, procurando alcançar esse objetivo, mas não existe uma coisa na organização mais voltada para essa formação, com o objetivo da empresa agregar esse valor a ela mesma. ”. (E1)

“A empresa poderia ter se preparado, ter feito um plano de projeto, ter ditado as regras para a consultoria e falado: 'Olha os processos que nós vamos adotar são esses, você vai seguir dessa forma, você vai se comunicar dessa forma e nós queremos essa forma de controle $e$ qualidade. '”. (E3)

Conforme Nonaka (2000), em uma economia onde a única certeza que se pode ter é a incerteza, somente o conhecimento constitui-se fonte segura de vantagem competitiva para as organizações. Thomas e Mullaly (2006), também destacaram a importância da capacidade organizacional em gerenciamento de projetos para a geração de valor. Assim como Shi (2011) também observou que a maturidade em gerenciamento de projetos possibilita as organizações a concretizarem os benefícios esperados dos projetos.

Portanto, considerando-se as reflexões destes autores e observando a realidade organizacional pela perspectiva dos entrevistados, pode-se perceber que a disseminação do conhecimento formal em gerenciamento de projetos pode ser considerada como uma oportunidade para a organização ABC.

Existem iniciativas individualizadas, segundo os entrevistados, na busca de formações ou de aprofundamentos em conhecimentos de gerenciamento de projetos. Nisto se observa o desejo destes indivíduos em se desenvolverem e se capacitarem neste tipo de conhecimento e internalizarem na organização melhores práticas que contribuam para o sucesso dos projetos organizacionais.

“Existem pessoas que se certificam por conta própria, para crescimento individual e essas pessoas, sim, elas contribuem para a organização, mas seu estudo é muito para o crescimento individual ainda, não é para crescimento do todo, ou para apoiar talvez numa área de projeto. Aqui nós não temos uma área de projetos especificamente. ”. (E1)

"Eu parei e pensei... eu nunca fiz um curso de projeto, de processo, de nada, e eu vou precisar ter esses conhecimentos, então eu fui buscar.... Então eu fui estudar projeto e processo... Nossa, no começo eu fiquei meio "lost”, perdida, mas aí falei, não, eu vou ter capacidade, eu vou conseguir, eu vou adquirir o máximo de conhecimento possível. ”. (E2) 
“...antes de entrar no projeto a minha gerente já havia conversado comigo que não saberia o que iria acontecer após a implantação, mas eu não estou com medo... o conhecimento que estou ganhando é fundamental. Não estou pensando em dinheiro no momento, nem no cansaço, só estou pensando no conhecimento que estou ganhando.”. (E4)

Ademais, projetos propõem-se a adicionar valor à organização. Conforme Görög (2006), projetos podem ser vistos como os meios pelos quais as organizações implementam as mudanças benéficas que estão implícitas em seus objetivos organizacionais estratégicos.

O valor proporcionado pelos projetos à organização pode ser percebido na fala dos indivíduos entrevistados quanto à sua percepção em relação às mudanças resultantes do projeto que foi tomado como estudo de caso para este trabalho.

"É um projeto que eu acho que agrega muito. Muito maior até do que se pensa. Eu acho que é importante. Sempre achei importante a entrada do SAP HCM. Ele otimiza as funcionalidades de muitas áreas, o financeiro vai ter benefício com isso, a manutenção, a produção.... Então a implantação faz a gente refletir que alguma coisa que a gente faz no nosso dia a dia pode ser melhorado. ". (E1)

“...eu estava vendo que nós teríamos que construir muitos processos novos, porque da frente de estrutura organizacional, a gente nunca teve nenhuma estrutura mapeada e fidedigna em sistema nenhum.... Eu acho que vai colocar muitas coisas no lugar. Então o fato de a gente ter uma atualização de estrutura real time foi incrível, até porque a estrutura do grupo é grande, são mais de cinco mil pessoas, são muitos negócios, cada negócio tem sua complexidade, cada negócio tem uma estrutura diferente. ”. (E2)

"Esse projeto eu vejo como fundamental para o patamar que a empresa busca. Há muito tempo vem se falando que a empresa deseja ter uma estrutura forte, que dê uma visibilidade, um controle maior.... Está se gerando maior integração da equipe de funcionários que está participando do projeto.... Esses profissionais estão enriquecendo seu background em termos de conhecimento de processos e que vai ser muito bom para organização. Olhando para o lado financeiro também está havendo um ganho bem significativo... está havendo redução significativa de custos com a nova solução. Há também um ganho no controle da informação e da consistência do processo.”. (E3)

Considerando que os projetos se propõem a oferecer benefícios à organização e que o gerenciamento de projetos formal contribui para o sucesso dos projetos, desenvolver as pessoas nas diferentes áreas de conhecimento em 
gerenciamento de projetos tende a ser um caminho para aumentar o sucesso das entregas e da satisfação das partes interessadas em relação aos projetos realizados.

Conforme Polanyi (1966) afirmou apropriadamente, o conhecimento reside na nossa habilidade de usá-lo. E dentre os diferentes saberes do gerenciamento de projetos, a comunicação é apontada como uma área de conhecimentos com alto impacto sobre o resultado do projeto. Para Dinsmore et al. (2014), a comunicação é a chave para o sucesso do projeto.

Quando perguntados sobre os pontos negativos do projeto, nota-se que os problemas de comunicação foram percebidos como fontes de preocupação para os participantes do projeto:

"Durante a execução do projeto você tem uma sobrecarga de trabalho que poderia ser melhor dimensionada, por causa de complicações de comunicação... alguém talvez comente: 'confiei que aqui estava sendo feito um trabalho, mas não estava, então talvez eu pudesse estar monitorando melhor essas atividades, agora atrasou e não percebi. Por exemplo, os key-users, que são nosso cliente interno, que são as pessoas que vão executar o sistema no dia, hoje eles estão parados no projeto esperando o término de atividades de outras pessoas. É aquela coisa da comunicação. Acho que é muito importante dentro dos projetos dar visibilidade, para cada um dentro da sua necessidade... cada um dentro do seu escopo de atividades precisa ter noção do que está acontecendo. Senão começa aquele burburinho, aquela desmotivação, o 'eu não sei o que está acontecendo', a sensação de que você poderia fazer mais ou poderia estar fazendo outra coisa. Porque você fica sem noção de tempo, não sabe se aquele atraso é de um dia ou eu se você poderia dimensionar melhor o tempo fazendo outra coisa.... É no momento do problema que você tem que manter a comunicação boa.... É você tentar trazer um pouco de informação para trazer um pouco de paz.... É um ponto que poderíamos melhorar. Por exemplo, eu estou passando por um momento em que os testes integrados estão atrasados e os key-users estão estranhando, eles sabem que alguma coisa acontece, mas não sabem o que. ”. (E1)

"A gente tinha o direcionamento que o projeto ia começar na primeira semana de janeiro. Chegou na primeira semana de janeiro não tinha nem baia, não tinha consultoria, nada ... A comunicação melhorou bastante, mas no começo era tenebroso. No começo era muito ruim.... Acho que uma coisa que [agora] incomoda grande parte de quem está no projeto é que a gente não está mais participando das reuniões de status... porque como tem falta de comunicação, eu não sei se o que está sendo reportado é a realidade. E eu tive muito problema de comunicação por causa disso, o que estava sendo reportado em uma reunião de status era uma coisa e o que era a realidade era outra coisa. Eu acho [também] que foi falha da consultoria não colocar os consultores para se entenderem. ”. (E2) 
"Eu acho que a comunicação no projeto foi muito fragmentada.... Existem muitas reuniões que não são geradas atas e nem são gerados documentos de comunicação para o time em relação às decisões ocorridas nessas reuniões. A gente tem vários controles paralelos. Isso dificulta muito a comunicação. Você tem que apontar um controle de informação na planilha $A$, depois outro controle na planilha B... os status são comunicados em arquivos separados... isso é um ponto negativo. Eu sofri impactos do tipo reportarem que tal etapa do projeto foi concluída e aí eu levantei meu braço e disse que não.... Por exemplo, para se ter uma ideia, eu fui ter visibilidade de cronograma só em agosto, que eu vi um cronograma do projeto, mas não sei nem em que versão estava, hoje não posso dizer que temos um baseline de cronograma do projeto, se tem eu nunca vi.”. (E3).

“...nosso time não tem essa expertise e eu vejo que poderiam melhorar em relação à comunicação formal dentro do nosso projeto.... Quando o projeto saiu da curva, eu acho que faltou o gerente de projetos deixar o cronograma mais claro para o time.... Não tem prazos de entrega. Então sinto falta disso. Isso não está bem comunicado.”. (E4)

Isto corrobora as informações de Kennedy et al. (2011), sobre às diversas pesquisas que apontam para a existência do relacionamento entre a comunicação e o desempenho do time do projeto.

É interessante observar que embora este tipo de relacionamento, a princípio, pareça apontar para questões apenas objetivas, de causa e efeito, há questões de ordem subjetiva que emergem da iteração comunicacional entre os participantes do projeto com impacto sobre o desempenho da equipe do projeto. Por exemplo, de acordo com o Guia PMBOK (PMI, 2013, p.291), os fatores ambientais da organização, os quais podem incluir a distribuição geográfica das instalações e dos recursos, devem ser levados em consideração, uma vez que as comunicações precisam ser adaptadas ao ambiente do projeto e da organização. Segundo os entrevistados, de fato, a ausência de um espaço físico que acomodasse todo o time do projeto ao longo dos diferentes ciclos de vida do projeto, foi percebido como um ponto negativo para o projeto. Contudo, percebe-se o desdobramento da dificuldade da comunicação em função do distanciamento físico dos indivíduos participantes do projeto, em questões que influenciaram na construção da realidade percebida pelos grupos que se formaram ao longo da existência do projeto, conforme se pode notar nas falas destacadas a seguir: 
"Outro problema é o espaço. A falta de um mesmo espaço para todos dificulta a comunicação. As pessoas ficam distantes. Então começa a se perder. Um grupo que está isolado começa a formar um grupo próprio e aí ficamos com vários grupos dentro de um projeto e aí rola uma informação lá que não acontece aqui, "aí eu estou sentida hoje”, "não gosto disso”, e aí a comunicação se perde. ”. (E1)

“...nosso planejamento era estarmos todos juntos numa mesma sala, este era o nosso desejo, mas não foi possível, isso foi uma barreira... os consultores também não tinham comunicação entre eles, tanto o time $A B C$, quanto o time Consultoria não tinha comunicação.... No início ficávamos distribuídos em grupos, porque não tínhamos uma sala fixa. Então eu acho que perdemos muito com isso, não termos todos reunidos e integrados num mesmo local. Não estar todo mundo junto foi uma barreira, foi muito ruim, foi um ponto negativo.”. (E4)

Deste modo, pode-se observar que aspectos relativos à comunicação afetaram os processos de subjetivação, de criação de sentido e de constituição da realidade percebida pelos indivíduos que participaram do processo de mudança organizacional, neste projeto. Confluente com esta perspectiva, o tópico a seguir busca aprofundar esta questão, através da análise das entrevistas realizada sob o aporte teórico da comunicação organizacional, em uma perspectiva da comunicação como um processo organizante, no qual a realidade organizacional é constituída por meio da comunicação.

\section{1 .2}

\section{Comunicação organizacional}

A primeira pergunta realizada na entrevista consistiu em um pedido à pessoa entrevistada para relatar brevemente seu histórico de entrada no projeto. Na segunda pergunta, em sequência, arguiu-se sobre a opinião do entrevistado quanto ao projeto estudado. O objetivo destas perguntas foi investigar a percepção do entrevistado quanto a como ele passou a integrar o projeto, ao mesmo tempo em que se buscou deixar o entrevistado à vontade tanto para estas, quanto para as próximas perguntas, para relatar segundo sua própria visão de mundo sua compreensão quanto ao fenômeno da mudança provocado pelo projeto estudado.

Nas respostas a estas duas perguntas iniciais observam-se nas falas que os entrevistados evocam acontecimentos anteriores para legitimarem e darem sentido à existência do Projeto Novos Horizontes. 
"Com a estabilização do SAP, desde aquela época já se visava fazer uma outra onda de projeto para implantação do SAP HCM. Na época em que nós implementamos o SAP já se visava ter um projeto novo, embora a gente não tivesse a dimensão de quanto tempo se passaria até ter um novo projeto.". (E1)

“É um primeiro degrau de uma escada que nós estamos construindo. No final teremos uma solução robusta, integrada, que nos permitirá ter algo que já se espera há muito tempo, que se já fala desde 2010, seis anos atrás, nós temos uma forte demanda para saber o que um colaborador dentro do grupo precisa ter de competências, não só institucionais ou organizacionais, mas competências técnicas, ter uma trilha, você conseguir fazer um plano de sucessão não somente para um público restrito, mas para todo grupo. ”. (E3)

“...nesse mesmo projeto da Central, na finalização, já se tinha essa ambição de trocar o sistema de folha de pagamento... isso é um sonho... te digo que este é um sonho antigo da organização...”. (E4).

“...é um projeto grande e na realidade quando eu vim para a $A B C$, principalmente quando eu tive uma proximidade com a folha atual, nós já sentíamos uma necessidade muito grande de uma mudança, para o nível de empresa que é a ABC, para o tamanho da empresa, para a complexidade da empresa, eu sempre achei que a folha atual era insuficiente, tinha muita coisa manual. E sabíamos que haviam sistemas que poderiam automatizar e nos dar mais garantia de assertividade em relação ao que é hoje.”. (E5).

“...e aí eu estava na [outra empresa] feliz da vida quando surgiu a oportunidade da ABC. A oportunidade da ABC ela foi um desafio muito grande porque ela tinha duas coisas. Ela tinha um item que era fazer a primarização do processo de negociação sindical... E o outro desafio era um desafio que se tratava de uma empresa que não havia inovado em tecnologia dentro da área de Recursos Humanos... então eu entrei com dois desafios, primarização e automatização. Trazer tecnologia e uma visão de processos para a ABC. (E7).

"A ideia de trocar a folha é muito antiga, só que foi brecada na época da implementação SAP, falaram, vamos implementar o SAP primeiro, aí depois teve estabilização, teve uma série de outras coisas, até que de 2013 a 2014 eu entrei e assumi forte essa questão de vamos migrar.”. (E8)

Essa construção de sentido através da reflexão e retrospecção são aderentes ao que é preconizado tanto por Weick, em relação ao sensemaking, quanto pelo pensamento da "Escola de Montreal”, modelo no qual as organizações são compreendidas como construções plurais instituídas nas práticas cotidianas de seus membros, compreendendo-se as organizações como sistemas de indivíduos em interação ativamente envolvidos em processos de criação e 
recriação de uma organização social através da geração de sentido (CASALI, 2009; WEICK, 2005).

Confluente com Taylor et al. (2004), o processo de organização é recursivo (WEICK, 1995), na medida em que as ações e interpretações da comunidade geram as circunstâncias que os membros da comunidade precisam abordar. Neste caso, o projeto Novos Horizontes.

Segundo Taylor e Casali (2010), a "Escola de Montreal” compreende as organizações através da comunicação, postulando que a organização emerge da comunicação por meio da dinâmica texto-conversação. Nessa dinâmica, em congruência com Taylor (2014), o texto representa uma manifestação do sensemaking humano (WEICK, 1995). E a elaboração do texto é como os membros da organização reflexivamente (GIDDENS, 2003) e retrospectivamente (WEICK, 1995) monitoram, racionalizam e engendram a ação da organização. Vinculada com os propósitos da organização, a conversação está ligada à atividade orientada ao objeto materialmente constituído. Em contraste, a comunicação por meio do texto constrói a organização como um objeto de reflexão e interpretação (TAYLOR et. al., 1996).

O nascimento do projeto evidencia o processo de coorientação, o qual irá gerar textos, os quais irão gerar objetos, que por sua vez irão gerar agenciamentos para a construção do projeto e, em última análise, ser em parte um processo constitutivo da própria organização.

Conforme Casali (2009, p. 119), a "teoria da coorientação” congrega a dimensão pela qual a comunicação deixa de ser instrumental para se tornar elemento constitutivo das organizações na construção e no compartilhamento de significados. Por meio da imbricação de diversas unidades relacionais A-B-X observa-se a emergência das organizações pela comunicação.

A imbricação de diferentes coorientações em relação à concepção do projeto é o meio pelo qual ocorre o nascimento do projeto, conforme pode ser exemplificada na fala destacada a seguir:

"Fizemos alguns levantamentos em 2014 com algumas adaptações, e aí em 2015 foi para frente o pré-projeto para o Novos Horizontes, vamos dizer assim. Então fizemos toda preparação para o Novos Horizontes, fizemos o BID, a RPF, tudo, colocamos a RFP no mercado, fechamos com a consultoria e aí em 2016 a gente começou o projeto.”. (E8) 
Uma importante imbricação que afetou significativamente todo o processo de mudança observado pelos participantes é destacada a seguir:

"E foi identificado dentro de DO... que a tecnologia era uma carência muito grande, muito grande dentro de DO. Foi quando a [Diretora de DO] chegou e disse: 'Não busca mais uma folha de pagamento, para tudo. Para tudo! '...porque você está buscando uma folha de pagamento, só que a gente tem que olhar as outras necessidades dentro da Organização e buscar no mercado um sistema que realmente atenda a necessidade da $A B C$. Aí eu comecei a envolver os meus outros pares para que eles pudessem embarcar nesse projeto junto com a gente e aí a gente começou a olhar uma solução integrada de Recursos Humanos.”. (E7)

A necessidade de uma solução integrada de recursos humanos, somada à intenção de inovação tecnológica, conduziram à escolha de uma solução híbrida composta de dois produtos, o ERP SAP HCM, em conjunto com o sistema cloud da SAP, o SuccessFactors Employee Central.

Uma vez iniciado o projeto de implementação da solução híbrida, artefatos de projeto começam a ser produzidos. Estes artefatos podem ser compreendidos sob a ótica do modelo da "Escola de Montreal" como objetos resultantes do processo de coorientação. Em congruência com Taylor et al. (2004), o alinhamento de diferentes orientações sujeito-objeto é onde a organização começa. Objetos surgem dentro dessa prática. Um importante artefato, ou objeto, recorrentemente citado nas entrevistas foi o cronograma do projeto, conforme destacasse-se a seguir:

"Mas ainda temos problemas de comunicação, embora estejamos tendo agora mais visibilidade do cronograma, eu acho que tomaram um certo cuidado depois da minha frase da curva (rs), então assim, por mais que o cronograma esteja mudando toda hora por conta dos imprevistos, eles têm se preocupado mais em chegar para a gente e dizer, 'olha esse cronograma aqui não serve mais para nada, o novo agora é esse aqui, foi feito replanejamento'. " (E2).

“...foi-se elaborando rascunhos de cronograma que nunca fecharam. Por exemplo, para se ter uma ideia, eu fui ter visibilidade de cronograma só em agosto, que eu vi um cronograma do projeto, mas não sei nem em que versão estava, hoje não posso dizer que temos um baseline de cronograma do projeto, se tem eu nunca vi.”. (E3). 
“...eu acho que faltou o gerente de projetos deixar o cronograma mais claro para o time... em certas reuniões eles não tinham cronograma para nos mostrar". (E4)

"Eu acho que lá no início nós tivemos um problema de organização com cronograma...". (E6)

Ao todo foram dezoito citações do cronograma, feitas pelos participantes nas entrevistas.

O cronograma, como texto produzido pelas interações anteriores, torna-se o agente responsável por efetivar as conexões com as próximas orientações que deverão ser alinhadas para a realização das atividades do projeto. Como observado por Taylor e Casali (2010, p.75), embora normalmente não percebamos as nossas conversas cotidianas serem mediadas pelos textos, contudo, os textos podem ser traduzidos para "realizar uma tarefa", não apenas em um contexto, mas em múltiplos contextos cuja única ligação uns com os outros é a de se referir e de recorrer aos mesmos textos. O texto é a ponte que passa por cima do abismo das conversações, isto é, entre as situações localizadas de interação. Um texto é gerado na comunicação e então, subsequentemente, instrui as conversações das diversas comunidades da organização.

Nas citações dos trechos de entrevistas relacionados com o cronograma, nota-se que os participantes claramente vinculam os problemas de comunicação com o cronograma do projeto. Isto evidencia que os participantes constroem colaborativamente um significado para o cronograma do projeto, relacionando-o com experiências retrospectivas vivenciadas em outros projetos, atribuindo-lhe autoridade como agente na orientação das atividades a serem realizadas no projeto. Em consonância com Taylor (2008), o cronograma torna-se um texto que possui autoridade para aqueles que nele trabalham.

Conforme evidenciado pelas falas a seguir, o principal ofensor para as dificuldades relacionadas com o cronograma foi, segundo a percepção dos participantes, o desconhecimento em relação ao produto SuccessFactors Employee Central e sua integração com o produto ERP SAP HCM:

“...o gerente do projeto [da consultoria] chegou aqui sem consultores $e$ sem conhecimento de causa, ele já tinha participado de outros projetos de implementação SAP, mas não de folha, e ele achava que ia acontecer de uma forma que não ia ser dessa forma, era o primeiro projeto no Brasil de 
implantação híbrida do SAP para recursos humanos, unificando o Employee Central com o SAP, e aí estava todo mundo meio desnorteado." (E2).

"A falta de transparência, lá trás, em relação ao conhecimento do produto, foi um problema que só descobrimos posteriormente no decorrer do projeto. Isso aí saiu totalmente do planejamento que havia sido feito... eu acho que faltaram com a verdade em relação à ferramenta EC [Employee Central] porque para mim os consultores que estão aqui..., aí novamente, a $A B C$ está sendo uma das pioneiras com essa ferramenta, sendo que para mim os consultores não têm o total domínio da ferramenta.”. (E4)

"A gente acha que é essa solução. Só que, quando a gente embarcou no projeto, não ficou muito claro para a gente que era uma inovação. E como inovação tinha um preço alto a ser pago. Não foi dito, não ficou muito claro, que ainda era uma tecnologia que não estava dominada... eu acho que se isso estivesse claro a gente teria colocado um prazo maior dentro do projeto, para gente trabalhar com algumas variáveis que não estavam na mão de ninguém. Não estava na mão da consultoria, nem estava na mão do fornecedor, que era algo de inovação. Inovação para eles! Então esse é um ponto que foi um ponto que a gente abraçou sem ter muito conhecimento e confiando integralmente na consultoria e trabalhamos com uma inovação dentro de um prazo normal de projeto.”. (E7)

"Com certeza a gente não tem no mercado profissionais que conheçam o produto por ser muito novo. A gente na verdade entrou num pioneirismo, então nosso cenário ficou um cenário que não tem em outro lugar, essa conjunção do EC com a folha do SAP HCM. Então, assim, o pioneirismo tem um preço... Um ponto que hoje assim eu vejo uma necessidade de fazer diferente, a gente entrou muito despreparado em relação ao que era, com uma falta real de conhecimento do que nós estávamos implementando... em relação à solução. E isso teve um determinado momento que deixou a gente sem visão...”. (E8)

O desconhecimento em relação à solução, segundo a percepção dos participantes, afetou seriamente a comunicação do projeto, resultando, inclusive em atritos entre os participantes do projeto:

"O consultor do SAP falava assim, isso aqui pode, o do Employee Central falava não pode. Aí toda hora a gente tem que mudar de decisão porque uma coisa funciona em um lugar e em outro não.”. (E2)

“O pessoal já está exaltado, já estão ocorrendo atritos.” (E4)

"No projeto Novos Horizontes nós percebemos as pessoas muito mais cansadas. Eu vejo um certo estresse. Em alguns momentos a consultoria 
não falando com a equipe ABC. Às vezes não falando a mesma língua, havendo um certo estresse...”. (E6)

O que se percebe ao se analisar a conexão destes eventos é que a comunicação falhou a partir do momento em que as orientações se desalinharam em relação às atividades a serem desenvolvidas no projeto, como reflexo da agência de um texto, representado pelo desconhecimento parcial da solução.

Conforme Taylor et al. (2004), a linguagem reside na comunicação como uma habilitação e uma restrição, bem como fora dela como um de seus ambientes. Nós moldamos nossos ambientes como eles nos moldam. Como os moldamos e somos moldados por eles é uma questão de prática. Vemos assim a organização e a comunicação como co-constitutivas, em outras palavras, a organização emerge através da comunicação.

Com efeito, os participantes concluíram que não somente eles contribuíram como agentes de construção do projeto, mas o projeto foi igualmente agente no processo de mudança dos próprios indivíduos:

"Não tem como você sair de um projeto desse da mesma forma como você entrou, é impossível...”. (E2)

"Saio do projeto uma nova pessoa. Toda essa troca com os outros times, como com o time de TI, essa experiência dos momentos quentes do projeto, a gente aprende a lidar com as pessoas de uma maneira diferente, em como contornar determinadas situações. Em relação às atividades do projeto tive novos aprendizados dentro do projeto e estou tendo um sonho realizado tanto no sentido profissional, quanto pessoal.”. (E4)

“...com certeza esse projeto mexeu com todo mundo, não tenho dúvida que nesse ínterim aconteceu um crescimento profissional, você entra de um jeito e sai de outro...”. (E8)

Essa construção de sentido corrobora a compreensão de Taylor (2008, p. 82) em relação à comunicação em projetos de implementação de $E R P$, à luz do modelo da "Escola de Montreal”:

"Muitas das dificuldades que os membros de equipe deste tipo de projeto enfrentam, está no fato de que muitos dos participantes do projeto ainda tendem a ignorar o simples fato de que uma organização, em sua própria essência, não é apenas um conjunto de práticas, para ser estruturalmente redesenhada. Ela é um texto - e é um texto que possui autoridade para aqueles que nela trabalham.” 
É importante ressaltar que as entrevistas evidenciaram que na percepção dos entrevistados, principalmente da liderança do projeto, a comunicação do projeto foi bem-sucedida se analisada em relação à realização das ações previstas no planejamento do gerenciamento das comunicações do projeto, conforme destacado a seguir:

"Esse contato com os stakeholders, com comunicação o tempo todo, foi fundamental. O problema é que aqui quando as coisas não são bem comunicadas então vira aquela bola de neve. As pessoas vão criando resistências. Como a comunicação foi bem-feita, essa parte eu posso te dizer que foi muito bem-feita, de alinhamento e comunicação com a liderança, isso foi essencial para que o projeto andasse, para que conseguíssemos as parcerias de ambos os lados. Eu acho que foi muito importante e está sendo ainda. ”. (E6).

"Olha, eu acho que a comunicação dentro do nosso projeto foi muito correta, ela foi no tempo certo, no momento certo, e na quantidade certa de informações. Tanto é que o ruído é zero para a Organização. ”. (E7)

Esta percepção é congruente com a visão da comunicação do projeto sob a perspectiva da comunicação nas organizações. Conforme Casali (2009), a comunicação nesta perspectiva é primariamente mecanicista, enfatizando a transmissão, os efeitos, a seleção de canais e o processamento de informação. Em concordância, Kunsch (2009) descreve que a comunicação quando vista como um fenômeno distinto, a compreensão de 'organização' é geralmente restrita a um 'local', ao passo que a concepção da 'comunicação' geralmente se restringe à interação social conceitualmente resumida em ações de transferência de informação.

Essa proposta de gerenciamento da comunicação também está aderente ao que é sugerido pelo Guia PMBOK (PMI, 2013, p. 287), no qual se descreve como boa prática para o gerenciamento das comunicações do projeto incluir os processos necessários para assegurar que as informações do projeto sejam planejadas, coletadas, criadas, distribuídas, armazenadas, recuperadas, gerenciadas, controladas, monitoradas e finalmente dispostas de maneira oportuna e apropriada.

Com efeito, pode-se perceber que a comunicação, na percepção dos entrevistados, atingiu os objetivos esperados se analisada na perspectiva da comunicação nas organizações. Estes objetivos são importantes, deve-se frisar, 
contudo, os diferentes problemas experenciados pelos participantes e que segundo suas percepções estão vinculados com a comunicação, evidenciam que existem oportunidades para que novas perspectivas contribuam para o papel da comunicação no gerenciamento de projetos. O espaço e a necessidade destas contribuições podem ser percebidos no sentimento final da liderança do projeto em relação às lições aprendidas deixadas pelo projeto estudado:

“...uma governança de comunicação deve ser bem-feita desde o início até o final, o aprendizado que eu tenho para mim é esse. Agente tem que planejar todas as mudanças.” (E8)

Em consonância com Taylor (2008, p. 82), a comunicação em muitos projetos de implementação ERP ainda é pensada apenas como o que se passa em uma organização. É importante entender que a organização é em si uma construção comunicativa.

Deste modo, considerando a percepção da comunicação em projetos capturada nesta pesquisa, analisada sob o prisma de diferentes perspectivas da comunicação organizacional oferecidas pela literatura e abarcadas no presente trabalho, o próximo subtópico apresenta uma possibilidade de categorização da comunicação em projetos organizacionais.

\section{1 .3}

\section{Categorização da Comunicação em Projetos}

A interpretação dos dados desta pesquisa se deu pelo método análise de conteúdo, respaldada pelas observações em loco, dado que o autor deste trabalho é membro da organização e do projeto tomados para o estudo de caso desta pesquisa. Como resultado do esforço empreendido, duas categorias emergiram das análises realizadas: a primeira categoria identificada foi classificada como Comunicação Instrumental do Projeto. A segunda categoria identificada foi agrupada sob o título de Comunicação Constitutiva do Projeto. 


\section{2}

\section{Comunicação Instrumental do Projeto}

O Guia PMBOK (PMI, 2013, p. 287) descreve o gerenciamento das comunicações do projeto como um conjunto de processos necessários para assegurar que as informações do projeto sejam planejadas, coletadas, criadas, distribuídas, armazenadas, recuperadas, gerenciadas, controladas, monitoradas e finalmente dispostas de maneira oportuna e apropriada.

Dinsmore et al. (2014) argumentam que entregar um sólido plano de gerenciamento de comunicação para todos os membros da equipe, patrocinadores e participantes (incluindo o cliente) é a chave para o sucesso de um projeto.

Nessa perspectiva, a abordagem da comunicação tem seu foco na transmissão da informação. Com efeito, conforme pode-se notar nos trechos de entrevistas destacados a seguir, a comunicação do projeto quando descrita explicitamente pelos entrevistados, é predominantemente instrumental:

"Durante a execução do projeto... alguém talvez comente: 'confiei que aqui estava sendo feito um trabalho, mas não estava, então talvez eu pudesse estar monitorando melhor essas atividades, agora atrasou e não percebi... É aquela coisa da comunicação. Acho que é muito importante dentro dos projetos dar visibilidade, para cada um dentro da sua necessidade... cada um dentro do seu escopo de atividades precisa ter noção do que está acontecendo.”. (E1)

Neste trecho da entrevista a referência é a um problema de comunicação percebido pelo membro do projeto. A relação é de causa e efeito. Os key-users do projeto não receberam a informação necessária no momento necessário, prejudicando o andamento das atividades do projeto e, por consequência, do desempenho do projeto.

Similarmente, outro membro do projeto expressa sua percepção de um problema de comunicação no projeto referindo-se ao conteúdo das reuniões de status report. A partir do momento em que se descontinuou a participação dos key-users nestas reuniões, houve a sensação de que o conteúdo reportado poderia não refletir a realidade fidedigna do desempenho do projeto. 
"Acho que uma coisa que [agora] incomoda grande parte de quem está no projeto é que a gente não está mais participando das reuniões de status... porque como tem falta de comunicação, eu não sei se o que está sendo reportado é a realidade. E eu tive muito problema de comunicação por causa disso, o que estava sendo reportado em uma reunião de status era uma coisa e o que era a realidade era outra coisa. ". (E2)

Novamente, a preocupação está no que está sendo comunicado. A comunicação é instrumento de informação para comunicar às partes interessadas o desempenho do projeto.

Outro membro do projeto corrobora esta percepção instrumental, descrevendo as dificuldades na coleta, armazenamento e distribuição da informação:

"Eu acho que a comunicação no projeto foi muito fragmentada.... Existem muitas reuniões que não são geradas atas e nem são gerados documentos de comunicação para o time em relação às decisões ocorridas nessas reuniões. A gente tem vários controles paralelos. Isso dificulta muito a comunicação. Você tem que apontar um controle de informação na planilha $A$, depois outro controle na planilha B.... os status são comunicados em arquivos separados... isso é um ponto negativo.". (E3).

Ainda mais um entrevistado se posiciona em relação aos problemas de comunicação percebidos no projeto ponderando sobre a visibilidade das informações para os membros do projeto:

“...nosso time não tem essa expertise e eu vejo que poderiam melhorar em relação à comunicação formal dentro do nosso projeto.... Quando o projeto saiu da curva, eu acho que faltou o gerente de projetos deixar o cronograma mais claro para o time.... Não tem prazos de entrega. Então sinto falta disso. Isso não está bem comunicado.”. (E4)

No gerenciamento das comunicações do projeto, pode ser observada a preocupação em se comunicar satisfatoriamente às partes interessadas externas ao projeto, com um viés igualmente instrumental, conforme destacado nos trechos das entrevistas a seguir:

"Esse contato com os stakeholders, com comunicação o tempo todo, foi fundamental... Como a comunicação foi bem-feita, essa parte eu posso te dizer que foi muito bem-feita, de alinhamento e comunicação com a liderança... ". (E6). 
"Olha, eu acho que a comunicação dentro do nosso projeto foi muito correta, ela foi no tempo certo, no momento certo, e na quantidade certa de informações.". (E7)

Em síntese, a comunicação na qual os indivíduos participantes do projeto se apropriam como referência para descrever, analisar, gerenciar a comunicação no projeto, é fortemente funcionalista e instrumental. Com efeito, conforme afirmado por Putnam (1982), o paradigma funcionalista é dominante tanto em teoria das organizações como em estudos de comunicação organizacional

Confluente com essa informação e o pragmatismo muitas das vezes requerido pela dinâmica dos projetos, a perspectiva da comunicação instrumental é explicita nas falas dos entrevistados quando se referem à comunicação no projeto. Entretanto, considerando as subjetividades inerentes à construção social da realidade provocada pelo processo de mudança gerado pelo projeto, a comunicação como constitutiva do projeto, e da própria organização, está implícita na descrição realizada pelos entrevistados acerca do projeto. Deste modo, a próxima categoria descreve a comunicação na perspectiva de constituinte do projeto e da própria organização.

\section{3}

\section{Comunicação Constitutiva do Projeto}

Putnam et al. (2004) cita Smith para apresentar três possíveis relacionamentos entre organização e comunicação: container, produção e equivalência. A visão deste relacionamento como container representa a perspectiva da comunicação nas organizações. Isto é, quando a comunicação é compreendida como instrumental, conforme abordado na categoria anterior, comunicação instrumental do projeto.

Já as perspectivas nas quais este relacionamento é representado pela visão de produção e equivalência, conforme observado por Kunsch (2009, p.69), salientam a importação de se ver a comunicação como organização e organização como comunicação.

A partir do desafio de explorar a equivalência entre comunicação e organização, este trabalho se utilizou do modelo proposto pela "Escola de Montreal', o qual oferece uma perspectiva única da comunicação organizacional, 
a qual propõe uma teoria comunicacional da constituição das organizações, isto é, uma visão das organizações nas comunicações.

Deste modo, na análise e interpretação das entrevistas realizadas, foi possível identificar a comunicação como constitutiva do projeto em um nível meso e como constitutiva da própria organização em um nível macro.

Foi observada a construção de sentido do projeto através da reflexão (GIDDENS, 2003) e retrospecção (WEICK, 1995), desde sua concepção. De fato, desde o seu nascimento, o projeto evidenciou o processo de coorientação, gerando textos, os quais geraram objetos, que por sua vez geraram agência para a construção do projeto, compondo um processo constitutivo da organização.

Em congruência com Taylor et al. (2004), a coorientação e a teoria de texto-conversação estão implicitamente presentes nesta construção, conforme destacado em relatos analisados como o que se referiu ao cronograma do projeto.

Se por um lado, o esforço empreendido para o sucesso da comunicação no projeto centrou-se nesta quando compreendida como positivista, o espaço e a necessidade de contribuições oferecidas por uma perspectiva interpretativista da comunicação como constitutiva do projeto e da organização, puderam ser percebidos no sentimento final expresso pela liderança do projeto:

“...uma governança de comunicação deve ser bem-feita desde o início até o final, o aprendizado que eu tenho para mim é esse.”. (E8)

Congruente com Taylor (2008, p. 82), a comunicação em muitos projetos de implementação ERP ainda é pensada apenas como o que se passa em uma organização. No entanto, o papel da comunicação se estende à construção do próprio e da organização, o que pode ser evidenciado pela interpretação da percepção expressa pelos indivíduos participantes do projeto estudado.

O próximo capítulo, apresentando as considerações finais do presente trabalho, aprofunda esta questão com as conclusões obtidas nesta pesquisa. 


\title{
Conclusão
}

Para Oswick (2005), nos últimos anos tornou-se cada vez mais difícil encontrar manuais atuais de gestão, especialmente os que são sobre mudança organizacional, que não façam uma referência obrigatória no seu preâmbulo introdutório ao fato de que vivemos num mundo turbulento e em rápida mutação.

Giddens (2003, p. 22), refletindo sobre a modernidade com razão diz que:

\begin{abstract}
"Uma das características mais óbvias que separa a era moderna de qualquer período anterior é seu extremo dinamismo. O mundo moderno é um 'mundo em disparada': não só o ritmo da mudança social é muito mais rápido que em qualquer sistema anterior; também a amplitude e a profundidade com que ela afeta práticas sociais e modos de comportamento preexistentes são maiores”.
\end{abstract}

Diante desse complexo cenário de constantes mudanças organizacionais, Kerzner (2002, p. 17) afirma apropriadamente que o desafio para a empresa que não quer ser apenas mais uma no mercado, consiste em realizar atividades nunca realizadas antes e que também não se repetirão no futuro.

Estas atividades são comumente realizadas através da realização de projetos, por meio dos quais as organizações buscam implementar as mudanças que compreendem serem benéficas e que estão implícitas em seus objetivos organizacionais estratégicos (GÖRÖG, 2006).

O guia internacional de melhores práticas em gerenciamento de projetos, Guia PMBOK (PMI, 2013), menciona que o sucesso do gerenciamento de projetos em uma organização é altamente dependente de um estilo de comunicação organizacional eficaz (PMI, 2013, p. 21), de tal forma que os gerentes de projetos devem passar a maior parte do tempo se comunicando com os membros da equipe e outras partes interessadas do projeto Guia PMBOK (PMI, 2013, p. 287).

Por este motivo, os esforços empreendidos no presente trabalho tiveram por objetivo a investigação de oportunidades de contribuição para o papel da comunicação no gerenciamento de projetos. 
Considerou-se, no entanto, que a mudança, se constitui antes de qualquer coisa, num processo que se concretiza socialmente nas interações cotidianas, o qual para ser compreendido em sua plenitude, tem que levar em consideração o contexto no qual se desenvolve, além de outras importantes dimensões, relativas à ação social na organização e às pessoas que dela participam (SILVA, 2001 p. 24).

Para tanto, buscou-se nessa dissertação explorar a comunicação em projetos partindo-se do pressuposto de que a comunicação organizacional é o meio pelo qual os indivíduos criam sentido (WEICK, 1995), assim como a comunicação organizacional é constitutiva da própria organização (TAYLOR et al. 2004).

Considerando a pergunta de partida dessa dissertação: “Como a comunicação é percebida pelos indivíduos e como esta afeta os processos de criação de sentido quando estes indivíduos participam de um processo de mudança organizacional provocado por um projeto de implementação de um ERP?”, oportunidades de contribuição para o papel da comunicação no gerenciamento de projetos foram investigadas, recorrendo-se à abordagem pioneira da “Escola de Montreal” em relação à comunicação organizacional, para lançar luz à novas possibilidades de compreensão e escrutínio da comunicação em projetos.

A “Escola de Montreal’ oferece uma perspectiva única da comunicação organizacional, porque propõe uma teoria comunicacional da constituição das organizações. Suas investigações se voltam para a emergência das organizações pela comunicação. O pensamento da "Escola de Montreal” incorpora a análise interpretativa dos fenômenos sociais como processos simbólicos. Nessa ótica, as organizações são construções plurais instituídas nas práticas cotidianas de seus membros, compreendendo-se as organizações como sistemas de indivíduos em interação ativamente envolvidos em processos de criação e recriação de uma organização social através da geração de sentido (CASALI, 2009; WEICK, 2005).

A "Escola de Montreal” postula que a organização emerge da comunicação por meio da dinâmica texto-conversação, isto é, os textos e as conversações ajudam a compreender melhor o fenômeno organizacional (TAYLOR e CASALI, 2010). A dinâmica texto-conversação representa um processo contínuo e circular em que conversações se transformam em texto e 
textos são traduzidos em conversações (TAYLOR et. al., 1996). As organizações emergem de tal dinâmica e são resultado dessas traduções (CASALI, 2009).

A organização, nesta proposição, é realizada através da coorientação à medida que os membros da organização se orientam simultaneamente para um objeto compartilhado de interesse e uns para com os outros. (TAYLOR et al., 2004). A coorientação representa uma relação de troca em que no mínimo dois agentes (A e B), os quais podem ser tanto indivíduos, quanto organizações que utilizam a linguagem para interação, têm sua atenção focada em um mesmo objeto (X), o qual representa elementos do ambiente material e social passíveis de interpretação e que incorporam significados (CASALI, 2009).

Deste modo, a estrutura teórica da "Escola de Montreal” propõe um novo olhar sobre a comunicação como constitutiva da organização através da compreensão da produção de sentido (sensemaking), da coorientação, da conversação e da produção de textos.

Essa visão da comunicação ao ser levada em consideração em ambiente de projetos proporciona, portanto, a possibilidade de se ampliar a compreensão do papel da comunicação no gerenciamento de projetos.

Para atingir os objetivos pretendidos, para o presente trabalho realizou-se uma pesquisa de campo, tomando-se como estudo de caso um projeto de implementação de um ERP SAP, restrita aos módulos exclusivamente de Recursos Humanos, realizado em uma renomada Companhia prestadora de serviços aos setores de comércio marítimo nacional e internacional no Brasil.

Foram realizadas entrevistas em profundidade com membros do projeto, as quais possibilitaram que o pesquisador obtivesse uma perspectiva profunda sobre os pensamentos, raciocínio, motivações e sentimentos dos participantes, em relação a visão do papel da comunicação no projeto, motivações e forma de pensar em relação ao projeto, sentimentos em relação aos outros membros do projeto e forma de pensar em relação ao gerenciamento de projetos na organização.

A análise das entrevistas foi realizada utilizando-se como método a análise de conteúdo, sendo a análise suportada pelo referencial teórico apresentado no segundo capítulo deste trabalho, buscando-se identificar como a comunicação é percebida pelos indivíduos entrevistados e como isto afetou a criação de sentido no processo de mudança provocado pelo projeto. 
Dentre as principais questões abordadas salientam-se:

- A importância dos projetos para as organizações na contemporaneidade;

- A disseminação do conhecimento formal em gerenciamento de projeto visando conduzir a organização a aumentar sua maturidade em projetos;

- Desenvolver as pessoas nas diferentes áreas de conhecimento em gerenciamento de projetos;

- A importância da comunicação para o sucesso do projeto;

- A necessidade de se compreender a comunicação em projetos como organizadora de uma realidade socialmente e recursivamente construída.

A Organização estudada possui um grande volume de projetos, considerando a importância destes para a inovação dentro de seu nicho de atuação e, consequentemente, para a manutenção da competitividade em um mundo marcado pelo estigma de constantes mudanças, de tal forma que as narrativas dos entrevistados revelaram suas percepções em relação a importância atribuída aos projetos da Companhia.

As narrativas revelaram ainda o desejo dos participantes do projeto de que a Organização avance na maturidade em projetos, destacando-se o fato de que a Companhia carece de mais utilização de conhecimento formal em gerenciamento de projetos, percebendo-se que a disseminação do conhecimento formal em gerenciamento de projetos pode ser considerada como uma oportunidade para a Organização estudada.

Considerando que os projetos se propõem a oferecer benefícios à organização e que o gerenciamento de projetos formal contribui para o sucesso dos projetos, desenvolver as pessoas nas diferentes áreas de conhecimento em gerenciamento de projetos tende a ser um caminho para aumentar o sucesso das entregas e da satisfação das partes interessadas em relação aos projetos realizados.

Quando perguntados sobre os pontos negativos do projeto, observou-se que os problemas de comunicação foram percebidos como fontes de preocupação para os participantes do projeto, corroborando as informações de Kennedy et. al. 
(2011), quanto às diversas pesquisas que apontam para a existência do relacionamento entre a comunicação e o desempenho do time do projeto. Em congruência, Dinsmore et al. (2014), compreende que o gerenciamento da comunicação é a chave para o sucesso de um projeto.

A comunicação no projeto estudado foi percebida pelos indivíduos entrevistados sob duas diferentes perspectivas. Em uma perspectiva a comunicação foi realizada com sucesso. Em outra, apresentou uma série de dificuldades.

Por um lado, a investigação apontou que o gerenciamento das comunicações do projeto planejou e executou toda a comunicação do projeto em uma perspectiva da comunicação nas organizações. Os stakeholders compreendidos pelos membros da organização, mas não membros do projeto, foram devidamente mapeados e informados no momento certo, com a informação que deveriam receber. Feedbacks positivos da liderança da Organização e de áreas impactadas revelaram um bom funcionamento da comunicação, seguindo-se o modelo básico e mecanicista de comunicação. Nessa perspectiva, a comunicação foi percebida como bem-sucedida.

Por outro lado, as narrativas revelaram também que diversos e diferentes problemas relacionados com a comunicação foram percebidos pelos participantes do projeto. Os entrevistados compreenderam que, em parte, a comunicação do projeto foi prejudicada pelo fato dos membros do projeto não receberem informações relevantes em tempo de projeto, como resultado de riscos não mapeados no planejamento e que se concretizaram em issues do projeto. Este ponto reforçou a importância e o valor de se disseminar na Companhia conhecimento formal em gerenciamento de projetos para o aumento da maturidade em projetos. Todavia, os problemas relatados revelaram ainda a necessidade de se ampliar a compreensão da comunicação para além das restrições do container organizacional.

As experiências relatadas pelos participantes revelaram uma construção da realidade social através da criação de sentido de forma reflexiva e recursiva, conforme previstos por Weick (1995; 2005) e pela corrente de pensamento da “Escola de Montreal”.

A análise das questões experenciadas pelos entrevistados evidenciou o processo de coorientação no projeto, o qual gerou textos, os quais irão geraram 
objetos, que por sua vez geraram agenciamentos para a evolução do projeto que, em última análise, se tornou parte de um processo constitutivo da própria organização.

Conforme Casali (2009, p. 119), a “teoria da coorientação” congrega a dimensão pela qual a comunicação deixa de ser instrumental para se tornar elemento constitutivo das organizações na construção e no compartilhamento de significados. Por meio da imbricação de diversas unidades relacionais A-B-X observa-se a emergência das organizações pela comunicação.

O que se percebeu ao se analisar os eventos mencionados nas entrevistas é que a comunicação falhou a partir do momento em que as orientações se desalinharam em relação às atividades a serem desenvolvidas no projeto.

Congruente com Taylor et al. (2004), a linguagem reside na comunicação como uma habilitação e uma restrição, bem como fora dela como um de seus ambientes. Deve-se considerar que nós moldamos nossos ambientes, assim como eles nos moldam. Vemos assim a organização e a comunicação como coconstitutivas, em outras palavras, a organização emergindo através da comunicação.

Com efeito, neste trabalho concluiu-se que não somente os indivíduos contribuíram como agentes de construção do projeto, mas o projeto foi igualmente agente no processo de mudança dos próprios indivíduos. Em consonância com Taylor (2008, p. 82), embora a comunicação em muitos projetos de implementação ERP ainda seja pensada apenas como o que se passa em uma organização, é necessário ampliarmos a compreensão do papel da comunicação em gerenciamento de projetos tendo-se em vista que a organização é em si uma construção comunicativa.

Como desdobramentos futuros, essa linha de pesquisa pode ser aprofundada através de investigação sobre como a comunicação relaciona-se com as questões identitárias dos indivíduos participantes de projetos organizacionais.

A contribuição desta dissertação tem por objetivo ainda estimular a exploração de outros aspectos teóricos da "Escola de Montreal” no campo de estudo da comunicação organizacional aplicada ao gerenciamento de projetos. 


\section{Referências bibliográficas}

BALBINOT, Z. \& BORIM-DE-SOUZA, R. Sustainable development and sustainability as quasi-objects of study in management. Management Research, 10, p. 153-186. 2012.

BALDESSAR, M.J. Jornalismo e tecnologia: pioneirismo e contradições na modernização da imprensa catarinense. Revista PJ: Br São Paulo, Edição n.5, 2005. Disponível em <http://www2.eca.usp.br/pjbr/arquivos/documento5.htm>. Acesso em: 22 de maio de 2016.

BAUER, M. Análise de conteúdo clássica: uma revisão. In: BAUER, MW; GASKELL, G. (Org.). Pesquisa qualitativa com texto, imagem e som: um manual prático. Petrópolis: Vozes, cap. 8, 2008.

BEATTY, R.C. \& WILLIAMS, C.D. ERP II: Best practices for successfully implementing an ERP upgrade. Communications of the ACM. Vol. 49 Issue 3, p. 105-109, 2006. ISSN: 00010782.

BURRELL, G.; MORGAN, G. Sociological paradigms and organisational analysis. London: Heinemann, 1979.

CASALI, A.M. Comunicação organizacional: considerações epistemológicas. Encontro Nacional Dos Programas De Pós-Graduação Em Administração ENANPAD, v. 28, 2004.

COLBARI, A. A análise de conteúdo e a pesquisa empírica qualitativa. In SOUZA, E.M. de. (Org.). Metodologias e analíticas qualitativas em pesquisa organizacional: Uma abordagem teórico-conceitual. EDUFES, 2014.

DEFOE, D.. An essay upon projects. London: Cassell \& Co., 1887.

CLELAND, D.I. The evolution of project management. IEEE Transactions on Engineering Management, v. 51, n. 4, 2004.

CLELAND, D.L.; GAREIS, R. Global Project Management Handbook: Planning, Organizing and Controlling International Projects, (Handbook). McGraw-Hill Professional, 2006.

CODAS, M.M.B. Gerência de Projetos: uma reflexão histórica. Revista de Administração de Empresas, v. 27, n. 1, 1987. p. 33-37.

DELLAGNELO, E.H.L. e SILVA, R.C. Análise de conteúdo e sua aplicação em pesquisa na administração. In: VIEIRA, M.M.F. e ZOVAIN D.M. (Orgs.). Pesquisa qualitativa em administração: teoria e prática. São Paulo: FGV. 2005. ISBN: 85-225-0530-6.

DINSMORE, C. \& CABANIS-BREWIN, J. The AMA handbook of project management. AMACOM: Div American Mgmt Assn, 2006.

GADDIS, P. The project manager. Harvard Business Review, 1959. 
GIDDENS, A. A constituição da sociedade. Edição n.2. São Paulo: Martins Fontes, 2003.

GÖRÖG, M. A broader approach to organisational project management maturity assessment. International Journal of Project Management, volume 34, 2016.

GULLEDGE, T. \& SIMON, G. The evolution of SAP implementation environments: A case study from a complex public sector project. Industrial Management \& Data Systems. 6, 714, 2005. ISSN: 0263-5577.

HELDMAN, K. Gerência de projetos: guia para o exame oficial do PMI. Elsevier, 2009.

ITU, International Telecommunication Union. ITU releases 2015 ICT figures: Statistics confirm ICT revolution of the past $\mathbf{1 5}$ years. Genebra, Suíça, 2015. Disponível em: <http://www.itu.int/net/pressoffice/press_releases/2015/17.aspx\#.

V0IMBZErK03>. Acesso em: 22 de maio de 2016.

KENNEDY, D.M.; McCOMB, S.A. \& VOZDOLSKA, R.R. An investigation of project complexity's influence on team communication using Monte Carlo simulation. Journal of Engineering and Technology Management, 2011, v. 28, n. 3.

KERZNER, H. Gestão de projetos: as melhores práticas; tradução Marco Antonio Viana Borges, Marcelo Klippel e Gustavo Severo de Borba. Porto Alegre: Bookman, 2002.

KUNSCH, M.M.K. Comunicação organizacional: conceitos e dimensões dos estudos e das práticas. In: MARCHIORI, M. Faces da cultura e da comunicação organizacional, São Caetano do Sul: Difusão, v. 2, p. 167-190, 2008.

LATOUR, B. Jamais fomos modernos: ensaio de antropologia simétrica. Rio de Janeiro: Editora 34, 1994.

MARTINS, M.V.S. O pensamento de Heráclito: uma aproximação com o pensamento de Parmênides. Brasília, 2007. 105p. Dissertação (Mestrado em Filosofia) - Departamento de Filosofia: Universidade de Brasília.

MORGAN, G.; BERGAMINI, C.W.; CODA, R. Imagens da Organização. São Paulo: Atlas, 2013.

NEVES, F.G.; BORGMAN, H.P. \& HEIER, H. Success Lies in the Eye of the Beholder: The Mismatch Between Perceived and Real IT Project Management Performance. 49th Hawaii International Conference on System Sciences, 2016.

NAVARRO, D. O Canal do Panamá: política e estratégia. Centro Universitário de Brasília - UniCEUB. Universitas Relações Internacionais, v. 13, n. 2, 2015.

OSWICK, C. et al. Looking forwards: discursive directions in organizational change. Journal of Organizational Change Management, v. 18, n. 4, p. 383-390, 2005. 
PATAH, L.A.; CARVALHO, M.M. de. Métodos de gestão de projetos e sucesso dos projetos: um estudo quantitativo do relacionamento entre estes conceitos. Revista de Gestão e Projetos-GeP, v. 3, n. 2, 2012.

PMI, Project Management Institute. Um Guia do Conhecimento em Gerenciamento de Projetos. Edição n. 5. Pensilvânia: Estados Unidos. Project Management Institute, 2013.

PMI, Pulse of the Profession. PMI's annual global survey of project, program and portfolio managers charting the major trends in project management. 8th Global Project Management Survey, 2016.

POLANYI, M. The tacit dimension. The University of Chicago Press, 1966.

PUTNAM, L.L.; PHILLIPS, N. \& CHAPMAN. Metáforas da comunicação e da organização In: CLEGG, S.R. et al., CALDAS, M. et al. (eds) Handbook de estudos organizacionais. Ação e análise organizacionais. São Paulo: Atlas, v. 3, p. 77-125, 2004.

PUTNAM, L.L. \& NICOTERA, A.M. Building theories of organization: the constitutive role of communication. New York: Routledge, 2009.

SHI, Q. Rethinking the implementation of project management: A Value Adding Path Map approach. International Journal of Project Management, v. 29, 2011.

SILVA, J.R.G. da. Comunicação e Mudança em Organizações Brasileiras: Desvendando um Quadro de Referência sob a Ótica do Sujeito e da Reconstrução de Identidades. Volume I. Rio de Janeiro, 2001. 179p. Tese (Doutorado em Administração) - Departamento de Administração: Pontifícia Universidade Católica do Rio de Janeiro.

TAYLOR, J.R.; e CASALI, A. Comunicação: o olhar da "Escola de Montreal” sobre o fenômeno organizacional. In: MARCHIORI, M. (Org.). Comunicação e Organização: reflexões, processos e práticas. São Caetano do Sul: Difusão Editora, 2010.

TAYLOR, J.R. \& VIRGILI, S. Why ERPs disappoint: The importance of getting the organizational text right. In $\mathrm{B}$. Grabot, A. Mayère \& I. Bazet, eds., ERP systems and organizational change: A sociological insight, pp. 59-84. London: Springer. (2008)

TAYLOR, J.R. et al. The communicational basis of organization: between the conversation and the text. Communication Theory. 1, 1, 1996. ISSN: 10503293.

THOMAS, J. \& MULLALY, M. Defining the Value of Project Management: In Search of Value, PMI Research Conference, PMI Research Conference. Project Management Institute, Montreal, Canada, 2006.

TURNER, J.R. Evolution of project management research as evidenced by papers published in the International Journal of Project Management. International Journal of Project Management, volume 28, 2010. 
UNESCO, United Nations Educational, Scientific and Cultural Organization. The Grand Canal. Disponível em: <http://whc.unesco.org/en/list/1443>. Acesso em: 25 de setembro de 2016.

WEICK, K.E. Sensemaking in Organizations. London: Sage, 1995.

WEICK, K.E.; SUTCLIFFE, K.M. \& OBSTFELD, D. Organizing and the process of sensemaking. Organization science 16, 4: 409-421, 2005.

WIDEMAN, R.M. The Framework. Part 1: The Rationale. Disponível em: <>. Acesso em 25 de setembro de 2016. 


\section{Anexo I}

\section{ROTEIRO DE ENTREVISTA SEMI-ESTRUTURADA}

Dados do Entrevistado

Nome:

Função:

Perguntas Primárias

1. Você poderia contar um pouco sobre sua formação, um breve histórico sobre seu tempo de atuação na empresa, e como você se inseriu no contexto do projeto Novos Horizontes?

2. O que você pensa sobre a implementação do projeto Novos Horizontes na organização?

3. Quais os pontos você elencaria como fatores positivos nesta implementação?

4. Quais os pontos você elencaria como fatores negativos nesta implementação?

5. Como você vê o papel da empresa nesta implementação?

6. Como você vê o seu papel no projeto?

7. Como você vê a comunicação na implementação do projeto? 
Perguntas Secundárias

1. Quem estava envolvido nesta situação?

2. Quais os fatores envolvidos?

3. Me dá um exemplo?

4. Você enxerga isso como uma barreira à comunicação?

5. Você enxerga isso como favorável à comunicação? 